Historic, archived document

Do not assume content reflects current scientific knowledge, policies, or practices. 
. 
A Brighter Jomorrow

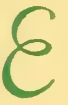

VER since the war began, the United Nations have been preparing for a Post-War World. Now, with an Allied Victory in sight, these preparations are being hastened-not with over-optimism, but with foresight. For 1944 may well prove to be a Year of Destiny, and we must be ready for the great changes which will challenge our Will to secure the greatest good for the greatest number.

Anc, ios us at home, this Spring should be one of great significance and hope. We can plan for the future, too-we can show our confidence in tomorrow's world by building for tomorrow.

In a modest way, Lovett's can help you plan and build-both for today and tomorrow. We think there is no more lasting structure than that which Nature can provide-nor is there one more beautiful. And Lovett's, in spite of the loss of many faithful employees and of other war-time handicaps, has continued to produce the same high quality stock as in former years, and is ready again with well grown Shrubs, Shade Trees, and a wealth of Ornamentals.

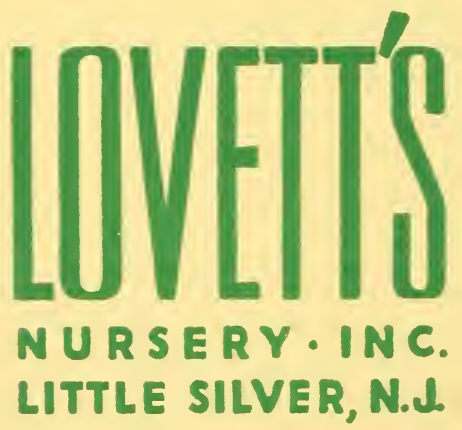

tra

Phone Red Bank 2200

Visitors are always welcome at our Nursery. Ou: location on the Jersey Shore is easily reached irom. all points, due to splendid highways, and to our cer: tral location between New York and Philadelphia. 


\section{HARDY SHRUBS}

\section{Evergreen and Deciduous}

Because our Shrubs are extremely sturdy, stocky specimens, they can be depended upon to give most satisfactory results. All of our Shrubs are graded according to the standards adopted by the American Association of Nurserymen.

\section{Special Shrub Offer}

These real bargain offers have become so decidedly popular that we feel almost compelled to repeat them again this season. All of these Shrubs are two years old or older, and will give quick and splendid results. All are correctly labelled and many choice sorts are included.

50 Assorted Shrubs, our choice of varieties, no more than 5 of a kind, at....14I/2c each

100 Assorted Shrubs, our choice of varieties, not less than 15 varieties, at....13 $1 / 2 \mathrm{c}$ each

500 Assorted Shrubs, our choice of varieties, no more than 20 of a kind, at....12 $1 / 2 \mathrm{c}$ each

1000 Assorted Shrubs, our choice of varieties, not less than 30 varieties, at.......12c each

When making out your order, kindly state whether you prefer mostly tall-growing shrubs, or medium-growing shrubs, or dwarf-growing sorts. If no preference is indicated, the order will be filled with varieties of assorted types.

The above prices do not include cost of packing. See Terms and Conditions of Sale on inside back cover.

\section{$10 \quad 100$}

ABELIA grandiflora (Glossy Abelia). 6 to $8 \mathrm{ft}$. Shell-pink, attractive, bell-shaped flowers among glossy foliage throughout entire summer. Almost evergreen but unfortunately not absolutely hardy, north of Philadelphia.
15 to 18 in., $\mathrm{B} \& \mathrm{~B}$
18 to 24 in., $B \& B$
$\$ 7.00 \$ 60.00$
to 3 ft., $B \& B$
$8.50 \quad 75.00$
$10.00 \quad 90.00$

ACANTHOPANAX pentaphyllum (Five-leaf Aralia). 7 to $8 \mathrm{ft}$. Being highly resistant to dust and smoke, this is a splendid shrub for city plantings. Carries deep, glossy green foliage on light gray branches.

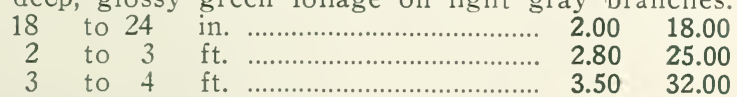

ACER palmatum (Japanese Greenleaf Maple). 15 to $18 \mathrm{ft}$. Actually a dwarf tree. The finely cut foliage turns brilliant colors in autumn.

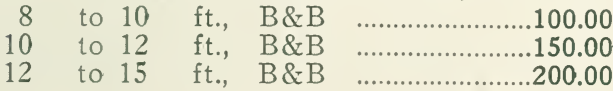


ACER-Concluded

\section{HARDY SHRUBS-Continued}

A. palmatum atropurpureum (Bloodleaf Maple). 8 to $10 \mathrm{ft}$. Our specimens are of a strain that can be depended upon to produce brilliant red foliage, which remains red throughout the entire summer. 15 to 18 in., $\mathrm{B} \& \mathrm{~B} \quad \ldots \ldots \ldots \ldots \ldots \ldots \ldots \ldots . . . . . . . . . .15 .00 \$ 135.00$ 18 to 24 in., B\&B …................... 20.00 180.00 2 to $21 / 2 \mathrm{ft}$., $B \& B$ $21 / 2$ to 3 ft., $B \& B$ 3 to 4 ft., $\mathrm{B} \& \mathrm{~B}$

A. palmatum atropurpureum dissectum (Purple Cutleaf Maple). 4 to $6 \mathrm{ft}$. True weepers, with deeply cut purple foliage.

Heavy specimen plants.

18 to 24 in. spread, B\&B …....... 30.00

2 to $2 \mathrm{I} / 2 \mathrm{ft}$. spread, $\mathrm{B} \& \mathrm{~B}$............ 40.00

$2 \mathrm{r} / 2$ to $3 \mathrm{ft}$. spread, $\mathrm{B} \& \mathrm{~B}$............. 50.00

3 to $3 \mathrm{I} / 2 \mathrm{ft}$. spread, $\mathrm{B} \& \mathrm{~B} \quad \ldots \ldots \ldots \ldots . .65 .00$

$3 \mathrm{I} / 2$ to $4 \mathrm{ft}$. spread, $\mathrm{B} \& \mathrm{~B}$............ 80.00

4 to $4 \mathrm{I} / 2 \mathrm{ft}$. spread, $\mathrm{B} \& \mathrm{~B}$..............120.00

AMORPHA fruticosa (Indigobush). 8 to $10 \mathrm{ft}$. Deep purple flowers in June. Distinct from all other shrubs and very attractive.

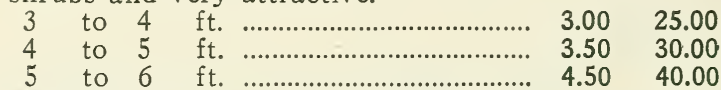

AMYGDALUS nana. See PRUNUS glandulosa, page 18.

ARONIA arbutifolia (Red Chokeberry). 7 to $8 \mathrm{ft}$. The glossy foliage, which assumes a rich autumn color, and the attractive red berries, which it carries until mid-winter, make this a splendid shrub especially for fall and winter effect.

$\begin{array}{rllll}18 & \text { to } 24 & \text { in. .......................................... } & 2.50 & 20.00 \\ 2 & \text { to } 3 & \mathrm{ft} . & 3.00 & 25.00\end{array}$

A. melanocarpa (Black Chokeberry). 8 to $10 \mathrm{ft}$. A vigorous bushy type shrub, which carries vast quantities of showy white flowers in May and persistant black berries, among the gorgeously colored foliage, in the fall.
18 to 24
in.
2.50
2 to 3

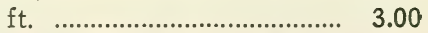

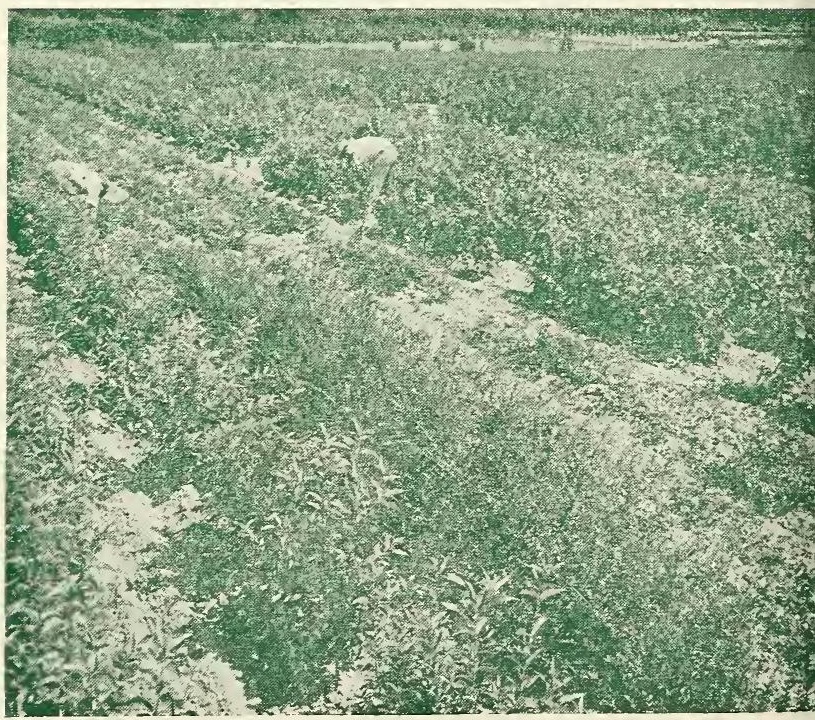

Some of our Hardy Shrubs 
Hardy Shrubs-Continued

\section{AZALEAS}

Not only are these shrubs very popular for landscape planting, but also most of the evergreen varieties are in great demand for forcing in greenhouses. Many florists have difficulty in obtaining sufficient of these gorgeous flowering plants to take care of the Easter and Mother's Day demand.

For many years we have specialized in the production of Azaleas, and this season we have as large a supply of compact, shapely plants as can be found anywhere in the world.

$$
10 \quad 100
$$

AZALEA amoena (Amoena Azalea). 3 to $4 \mathrm{ft}$. One of the hardiest and most popular of the evergreen Azaleas, with attractive purple-red flowers. Foliage turns bronze in winter.
10 to 12 in. spread, $B \& B$
12 to 15 in. spread, $B \& B$
15 to 18 in. spread, $B \& B$
18 to 24 in. spread, B\&B
$\$ 8.50 \$ 75.00$
…........... $12.50 \quad 110.00$
$15.00 \quad 135.00$
2 to $21 / 2 \mathrm{ft}$. spread, $B \& B$
$21 / 2$ to $3 \mathrm{ft}$. spread, $B \& B$
$20.00 \quad 175.00$
$23.50 \quad 220.00$
3 to $4 \mathrm{ft}$. spread, $\mathrm{B} \& \mathrm{~B}$
$28.50 \quad 260.00$
$42.50 \quad 400.00$

A. amoena coccinea (Red Amoena Azalea). $4 \mathrm{ft}$. Similar to the above variety excepting for the flowers, which are blood red.

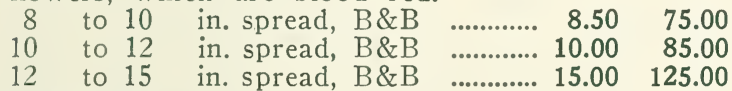

A. calendulacea (Flame Azalea), 5 to $6 \mathrm{ft}$. Loveliest of our country's native Azaleas, this gaudy plant is a riot of burnt-orange flowers in late spring.

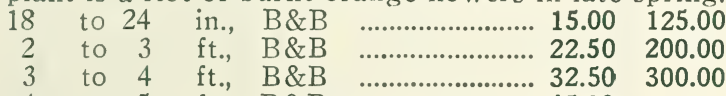
4 to 5 ft., B \&B ……................... 45.00

A. hinamoyo (Hinamoyo Azalea). 4 to $5 \mathrm{ft}$. Upright growing, producing very attractive bright pink flowers in May.
12 to 15
in. spread, $B \& B$
$15.00 \quad 125.00$
15 to 18 in. spread, $B \& B$
$17.50 \quad 150.00$

A. hinodegiri (Hinodegiri Azalea). 4 to $5 \mathrm{ft}$. Undoubtedly the most popular of all Azaleas, with many large, bright scarlet flowers gracing its attractive evergreen foliage in May. This is probably the most brilliant of all Azaleas.

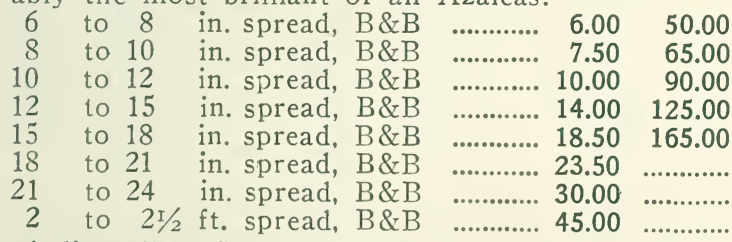

A. indica alba (Snow Azalea). 4 to $5 \mathrm{ft}$. Best, by far, of the white flowered evergreen Azaleas, with its large snow-white blooms appearing in late spring, offering a superb contrast to Hinodegiri.

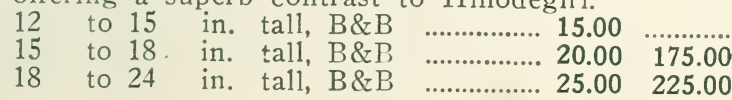


LOVETT'S NURSERY, INC.

HARDY SHRUBS-Continued

AZALEAS-Ccntinued

$10 \quad 100$

A. indica lilacina (Lilac Azalea). 4 to $5 \mathrm{ft}$. An evergreen variety of sturdy growth. The flowers, borne throughout May, are clear light lilac in color.
15 to 18 in., $\mathrm{B} \& \mathrm{~B}$
18 to 24 in., $\mathrm{B} \& \mathrm{~B}$
2 to $21 / 2 \mathrm{ft}$., $\quad B \& B$
$2 \mathrm{x} / 2$ to $3 \mathrm{ft}$., $\mathrm{B} \& \mathrm{~B}$
$\$ 16.50 \$ 150.00$
$22.50 \quad 200.00$
$27.50 \quad 250.00$
35.00

A. J. T. Lovett (J. T. Lovett Azalea). 2 to $3 \mathrm{ft}$. We have long been justly proud of this introduction which will stretch your Azalea season into midSummer, when it bears its big, attractive, carmine flowers. This spreading evergreen is worthy of a featured place on your customer's property.
12 to 15 in. spread, $B \& B$
15 to 18 in. spread, $B \& B$
18 to 24 in. spread, $B \& B$
2 to $2 \mathrm{I} / 2 \mathrm{ft}$. spread, $B \& B$
$2 \mathrm{~T} / 2$ to $3 \mathrm{ft}$. spread, $\mathrm{B} \& \mathrm{~B}$
$10.00 \quad 85.00$
$12.50 \quad 110.00$
$17.50 \quad 150.00$
$22.50 \quad 200.00$
$27.50 \quad 250.00$

A. kaempferi (Torch Azalea). 4 to $5 \mathrm{ft}$. Orange-red to salmon-pink flowers in late Spring. Very hardy. Of rather upright growth.
15 to 18 in. tall, $\mathrm{B} \& \mathrm{~B}$
18 to 24 in. tall, $B \& B$
$15.00 \quad 125.00$
2 to $2 \mathrm{r} / 2 \mathrm{ft}$. tall, $\mathrm{B} \& \mathrm{~B}$
$20.00 \quad 175.00$
$2 \mathrm{r} / 2$ to $3 \mathrm{ft}$. tall, $B \& \mathrm{~B}$
$25.00 \quad 225.00$

A. kurume, Flame. $3 \mathrm{ft}$. Brilliant red with coppery suffusion. Early. Of rather upright growth, and one of the hardiest evergreen sorts.
12 to 15 in. tall, B\&B
15 to 18 in. tall, $\mathrm{B} \& \mathrm{~B}$
$12.50 \quad 110.00$
18 to 24 in. tall, $B \& B$
$15.00 \quad 135.00$
24 to 30 in. tall, $B \& B$
$20.00 \quad 175.00$
$27.50 \quad 250.00$

A. kurume, Salmon Beauty. The bright salmon flowers of this evergreen variety are "hose-in-hose."
6 to 8 in. spread, B\&B
7.00
60.00

A. kurume, Snow. $3 \mathrm{ft}$. A particularly attractive evergreen sort which bears large clusters of white flowers.
4 to 6 in. spread, $B \& B$
6 to 8 in. spread, B.\&B
$5.50 \quad 45.00$
$7.00 \quad 60.00$

A. kurume, Sweetbriar. $3 \mathrm{ft}$. Clear pink flowers, which do not fade, make this plant a thing of beauty when in bloom in late Sipring.

\begin{tabular}{|c|c|c|c|c|}
\hline 5 to 8 & in. spread, $B \& B$ & & 6.00 & 50.00 \\
\hline & in. spread, $B \& B$ & ............... & 8.00 & 70.00 \\
\hline to 12 & in. spread, B\&B & ................ & 10.00 & 90.00 \\
\hline 15 & spread, B\&B & .............. & 14.00 & 125.00 \\
\hline 18 & in. spread, $B \& B$ & ................. & 17.50 & 150.00 \\
\hline & in. spread, B\&B & ............... & 22.50 & 200.0 \\
\hline
\end{tabular}

A. ledifolia magnifica (Blush Azalea). 4 to $5 \mathrm{ft}$. Many big, blush-white flowers, sprinkled with conspicuous wine-red dots on the upper petals, make this plant a charming sight in late Spring.
12 to 15 in. tall, $\mathrm{B} \& \mathrm{~B}$
10.00
15 to 18 in. tall, $B \& B$
18 to 24 in. tall, $B \& B$
$\begin{array}{ll}12.50 & 100.00\end{array}$
2 to $2 \mathrm{I} / 2 \mathrm{ft}$. tall, $B \& B$
$15.00 \quad 125.00$
$17.50 \quad 150.00$
$2 \mathrm{r} / 2$ to $3 \mathrm{ft}$. tall, $\mathrm{B} \& \mathrm{~B}$
$20.00 \quad 175.00$ 
HARDY SHRUBS-Contimued

10. 100

A. macrantha (Red Salmon Azalea). $4 \mathrm{ft}$. Quick growing and hardy, with salmon-red flowers very late in the season. Of rather broad spreading growth.

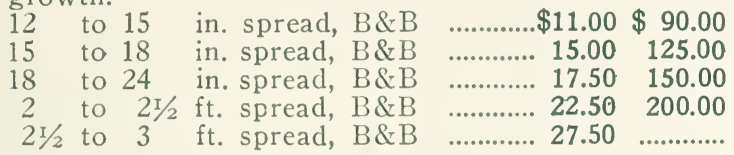

A. macrantha Orange Late. 2 to $3 \mathrm{ft}$. A very beautiful, extremely free flowering variety, the flowers being of a decidedly attractive bright orange color. 18 to 24 in. spread, B\&B ........... 22.50 200.00 2 to $2 \mathrm{~T} / 2 \mathrm{ft}$. spread, $\mathrm{B} \& \mathrm{~B} \quad \ldots \ldots \ldots \ldots . . . .27 .50 \quad 250.00$ $2 \frac{1}{2}$ to $3 \mathrm{ft}$. spread, B\&B ............ $35.00 \quad 325.00$

A. macronulatum (Korean Azalea). $5 \mathrm{ft}$. Blooming very early in the Spring, the pale lilac flowers of this hardy Azalea form a beautiful contrast to the yellow blooms of Forsythia.

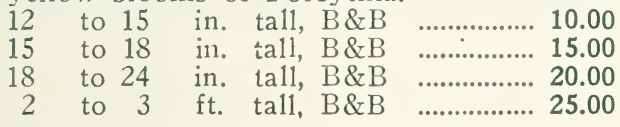

A. maxwelli (Maxwell Azalea). 3 to $4 \mathrm{ft}$. One of the hardier sorts. In late spring it produces huge carmine-red flowers similar in appearance and size to Rhododendrons.
12 to 15 in. tall, $B \& B$
$11.50 \quad 100.00$
15 to 18 in. tall, $B \& B$
$15.00 \quad 125.00$
18 to 24 in. tall, B\&B
$19.00 \quad 165.00$

A. mollis (Chinese Azalea). $5 \mathrm{ft}$. In May and June this showy plant bears big flowers in attractive shades of yellow and orange.
12
to 15
in. tall, $\mathrm{B} \& \mathrm{~B}$
$11.50 \quad 100.00$
15 to 18 in. tall, $\mathrm{B} \& \mathrm{~B}$
$16.50 \quad 150.00$
18 to 24 in. tall, $B \& B$
22.50

A. Pink Beauty. $4 \mathrm{ft}$. Big, beautiful single flowers cf lovely soft pink. A very strong, sturdy growing variety.

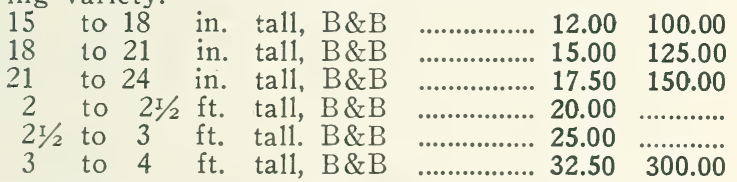

A. schlippenbachi (Royal Azalea). 6 to $7 \mathrm{ft}$. A gaudy sight in mid-Spring with its big pink flowers standing out against the purplish twigs; and the foliage colors up most beautifully in autumn.

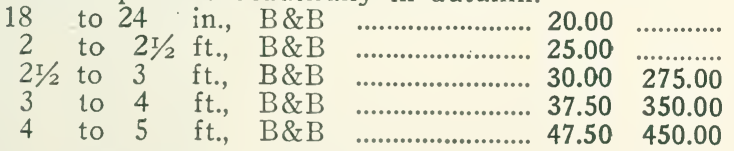

A. Sherwoodi. 2 to $3 \mathrm{ft}$. One of the hardiest of all varieties and a very strong grower. Produces an abundance of very attractive orchid colored rather large flowers.

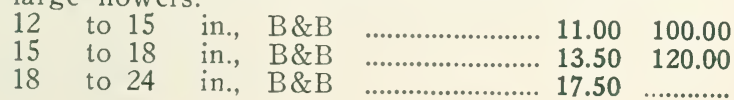


HARDY SHRUBS-Continued

AZALEAS-Concluded

10100

A. yodogawa (Yodogawa Azalea). 3 to $4 \mathrm{ft}$. An extra hardy sort with many double lavender-rose flowers in May, delicately beautiful.

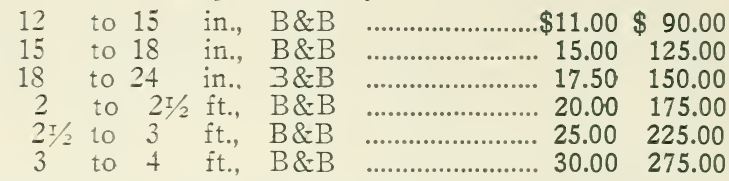

BENZOIN aestivale (Spicebush). 10 to $12 \mathrm{ft}$. Yellow April flowers, scarlet Summer berries, beautiful Fall foliage.

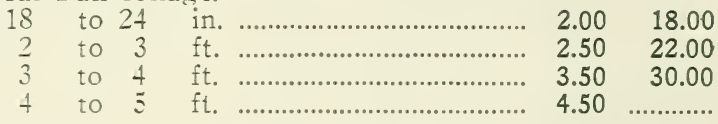

\section{BERBERIS (Barberry)}

BERBERIS julianae (Wintergreen Barberry). 4 to $5 \mathrm{ft}$. Unusual Barberry, erect, yet compact, with glossy evergreen foliage. Makes a splendid hedge and also is appropriate for planting with other broad-leared Evergreens.

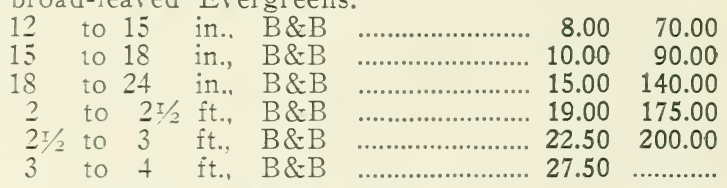

B. mentorensis (Mentor Barberry) (U. S. Plant. Patent No. 99). 3 to $3 \mathrm{~T} / 2 \mathrm{ft}$. Adapted to intense heat and drought, this broad but upright growing Barberry requires no pruning. It carries its deep green foliage to the ground, forming a true barrier to man or beast, when used as a hedge.

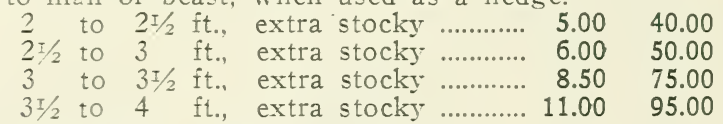

B. thunbergi (Tapanese Barberry). 4 to $5 \mathrm{ft}$. Immensely popular for a low dense hedge with its arching slender branches that carry a wealth of scarlet berries in autumn and winter. The foliage is richly shaded during the fall months. Our plants this season are especially sturdy. 3 yrs. old, stocky transplanted plants.

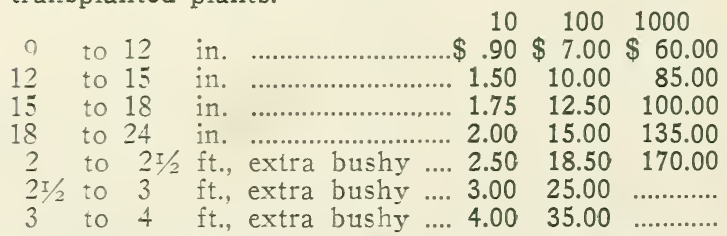

B. thunbergi Seedlings. These sturdy 2-year seedlings are very superior to light 1-year old plants such as are frequently offered.

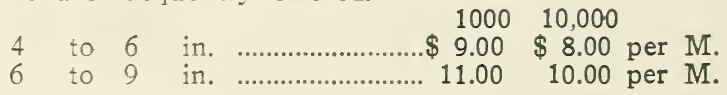


HARDY Shrubs-Continued

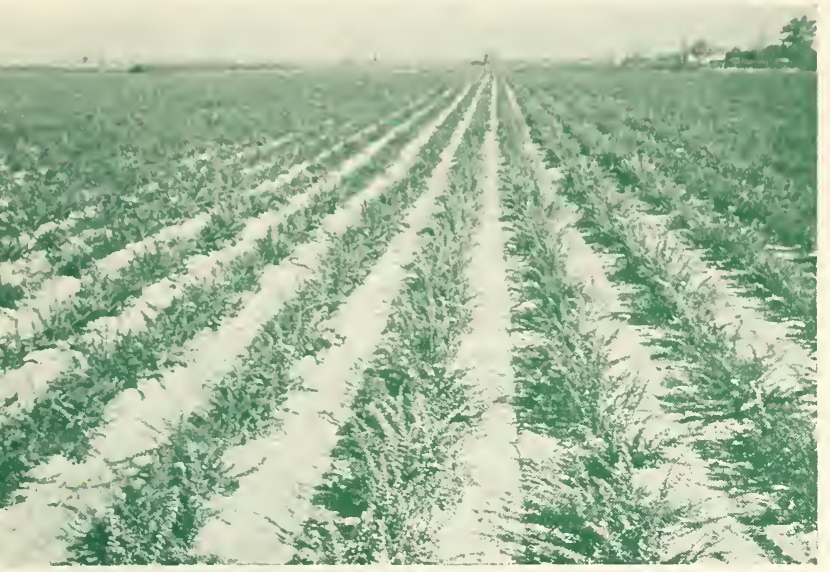

We grow acres of Berberis Thunbergi

10

100

B. thunbergi atropurpurea (Redleaf Japanese Barberry). 4 to $5 \mathrm{ft}$. We are growing plants of a superior strain,- the foliage, which they carry, approaches in brilliancy that borne by the best of Blood-leaf Maples.

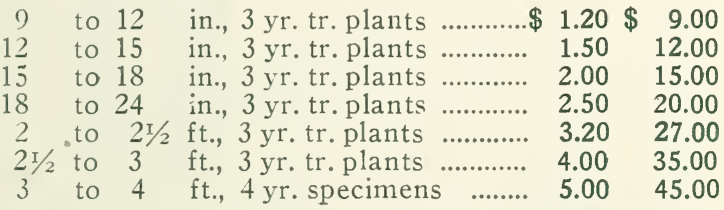

B. thunbergi erecta (Truehedge Columnberry) (U. S. Plant Patent No. 110). A very valuable introduction. Spire-like in habit, and with attractive small Boxwood-like foliage which assumes a gorgeous red color in autumn, at which time the plants also carry vast quantities of Holly-like red berries.

$\begin{array}{lll}10 & 100 \quad 1000\end{array}$

15 to 18 in., 3 yr. trans.......\$2.70 $\$ 22.00 \$ 200.00$

18 to 24 in., 4 yr. trans...... $3.30 \quad 28.00 \quad 250.00$

2 to $2 \mathrm{r} / 2 \mathrm{ft} ., 4 \mathrm{yr}$. trans. ...... $4.00 \quad 35.00 \quad 300.00$ $2 \mathrm{r} / 2$ to 3 ft., 4 yr. trans....... $5.50 \quad 45.00 \quad 400.00$

B. thunbergi minor (Box Barberry). 2 to $3 \mathrm{ft}$. A dwarf, compact growing variety, splendid for edging.

10100

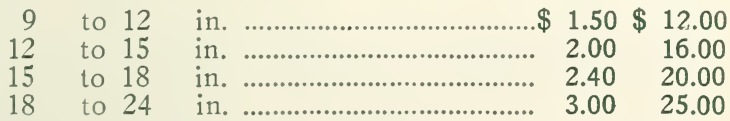

BIJDDLEIA alternifolia (Alternate Leaf Butterflybush). 8 to $10 \mathrm{ft}$. Lilac purple flowers almost envelop this wide spreading shrub in mid-summer.
3 to $4 \mathrm{ft}$.
4 to $5 \mathrm{ft}$. 
HARDY SHRUBS-Continued

\section{BUDDLEIA-Concluded}

10100

B. "Charming." $5 \mathrm{ft}$. Many long sprays of lavenderpink bloom in late summer.

2 yr. No. 1

$\$ 2.70 \$ 22.00$

B. farquhari (Farquhar Butterflybush). 5 ft. From mid-July until frost, this lovely sort bears countless fragrant lavender flowers.

2 yr. No. 1

22.00

B. Hartwegi (Hartweg Butterflybush). 5 ft. Dark lavender flowers. A profitable cut flower variety. 2 y. No. 1 .......................................... $2.70 \quad 22.00$

B. Ile de France (Butterfly Shrub). 4 it. Dark purple, fragrant flowers.

2 yr. No. 1 ........................................ $2.70 \quad 22.00$

B. Orchid Beauty (Butterfly Shrub). Orchid shade with brilliant orange eye.

2 yr. No. 1

$3.00 \quad 25.00$

BUXUS sempervirens (Boxwood). 12 to $15 \mathrm{ft}$. Excellent as individual specimens and also for making attractive evergreen hedges. Of quite rapid growth. 15 to 18 in., $\mathrm{B} \& \mathrm{~B}$

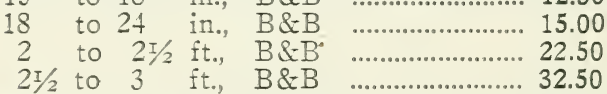

B. sempervirens suffruticosa (True Dwarf Box). 3 to $4 \mathrm{ft}$. The rare old English Boxwood, sweetly fragrant, slow growing, compact, most attractive, and practically everlasting. Ideal for edging or for a formal hedge. Delights in partial shade.

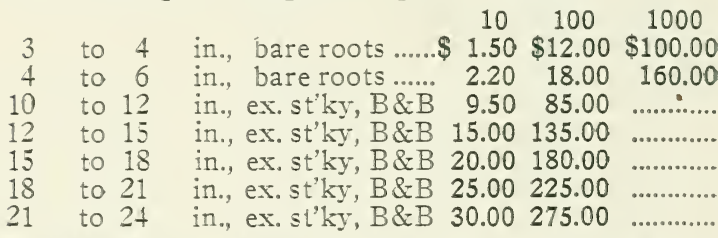

CALLICARPA purpurea (Chinese Beautyberry). 4 to $5 \mathrm{ft}$. Little clusters of shiny deep mauve berries are studded along the willowy branches. Makes an attractive house decoration.
2 to 3 it.
$10 \quad 100$
3 to 4
$\$ 2.50 \$ 22.00$
$3.20 \quad 28.00$

CALYCANTHUS floridus (Sweetshrub). 4 to $5 \mathrm{ft}$. Double, chocolate-colored, Strawberry-scented bloom, in April. An old-time favorite.
18
to 24
in.
3.50

CARAGANA arborescens (Siberian Peatree). 10 to $12 \mathrm{ft}$. Yellow sweet-pea shaped flowers borne in May and June on a broad spreading shrub.

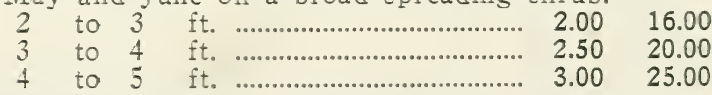

CEPHALANTHUS occidentalis (Button Bush). 12 to $15 \mathrm{ft}$. Fuzzy round white flowers, produced in July and August over rich green leaves, make a pretty picture. Will grow in fairly high, well drained soil, but prefers moist location.

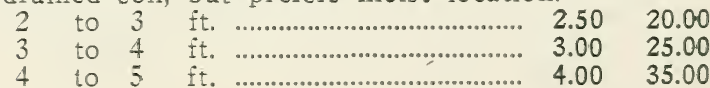


Hardy Shrubs-Continued

CERCIS canadensis (Judas-tree). 20 to $25 \mathrm{ft}$. Small, rosy pink flowers, like Sweet Peas, almost cover the bare branches in April.

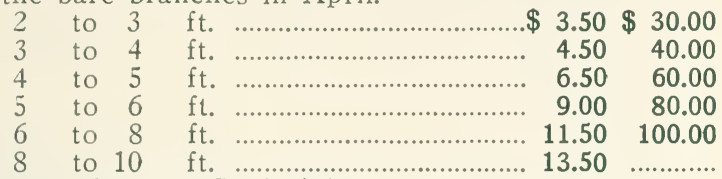

CHIONANTHUS virginica (White Fringe). 20 to

$25 \mathrm{ft}$. Produces large loose sprays of fragrant white flowers. Later in the year it bears dark purple plum-like fruits, which are relished by birds. 2 to 3 ft. ...................................... $4.00 \quad 35.00$ 3 to 4 ft. ............................................ $5.00 \quad 45.00$

CLETHRA alnifolia (Summersweet). 4 to $5 \mathrm{ft}$. Spikes of deliciously fragrant white flowers in summer. Thrives in shady, moist locations.
18 to 24 in.
2.50
2 to $21 / 2 \mathrm{ft}$.
3.50
$2 \mathrm{I} / 2$ to $3 \mathrm{ft}$
4.50

CORNUS alba (Redbranched Dogwood). 8 to 10 $\mathrm{ft}$. Gaudy in winter with red bark and porcelainblue fruits standing out well against the snow.

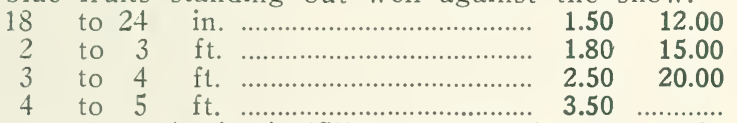

C. amomum (sericea) (Silky Dogwood). 8 to $9 \mathrm{ft}$. Bluish fruits in the fall and purple branches for winter color. Good in swampy areas.

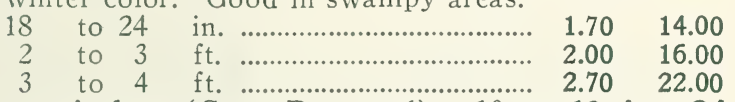

C. paniculata (Gray Dogwood). 10 to $12 \mathrm{ft}$. Of rather upright growth, splendid for mass plantings, with clusters of white winter berries on red stems. $2103 \mathrm{ft}+\ldots . .62 .50$

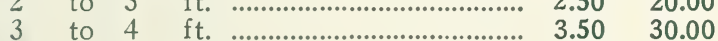

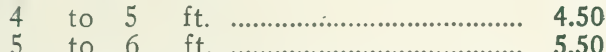

C. stolonifera lutea (Goldentwig Dogwood). 6 to 8 $\mathrm{ft}$. The decidedly briliant, golden yellow bark makes this a splendid variety for winter effect.

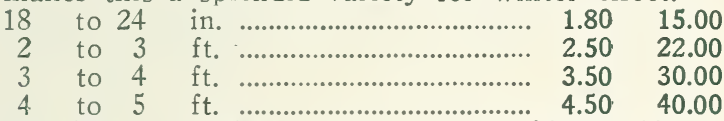

C. florida, C. florida rubra. See Deciduous Trees, pages 33 and 34 .

COTONEASTER divaricata (Spreading Cotoneaster). 4 to $6 \mathrm{ft}$. Studded with scarlet fruit, this none too well known shrub deserves a choice location in the shrub border. Being of vigorous spreading growth, with clean looking foliage, it also makes a lovely hedge.

4 to 5 ft., $\quad$ B\&B $\quad$......................... $17.50 \quad 150.00$ 5 to 6 ft., $\quad$ B\&B $\ldots$...................... $22.50 \quad 200.00$

CYDONIA japonica (Flowering Quince). 4 to 5 ft. Good for border edging, specimen plant, or hedge, with its deep green, dense foliage; a mass of rich scarlet flowers in spring, followed by small, golden Quince-like fruit, spicily fragrant in the fall.

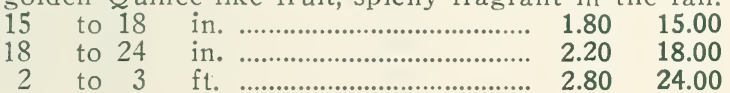




\section{HARDY SHRUBS-Continued}

10100

DAPHNE cneorum (Rose Daphne). $1 \mathrm{ft}$. This perfect dwarf evergreen is rapidly increasing in popularity because of the delightiully fragrant and beautiful pink flowers which it carries both in spring and fall. It is also in great demand for forcing under glass.

Bushy, 6 to 9 in. spread, B\&B $\$ 4.50 \$ 40.00$ Bushy, 9 to 12 in. spread, B\&B $7.00 \quad 60.00$ Bushy, 12 to 15 in. spread, B\&B $9.00 \quad 80.00$ Bushy, 15 to 18 in. spread, B\&-B $11.50 \quad 100.00$ Bushy, 18 to 21 in. spread, B\&B 15.00135 .00

D. mezereum (February Daphne). 3 ft. Many fragrant wine-red blossoms in early March, and bright scarlet fruit in late summer.

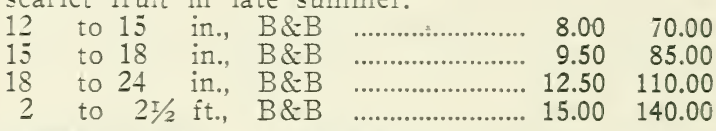

DESMODIUM. See LESPEDEZA bicolor, page 14.

DEUTZIA gracilis (Slender Deutzia). $2 \mathrm{it.}$ This dwarf, dense, round-topped bush bears many lovely racemes of white flowers in late spring.
12 to 15
in.
2.00
15 to 18 in.
2.50

D. gracilis rosea (Rose Panicle Deutzia). 3 it. Similar to above but of taller growth, and with pinkish flowers.

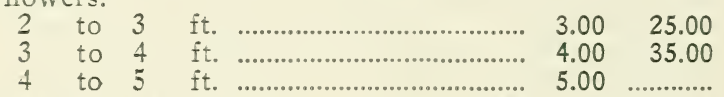

D. Pride of Rochester. 9 to $10 \mathrm{ft}$. Most popular of the Deutzias, with countless flower-tassels in late spring, frequently blushing to a true pink.

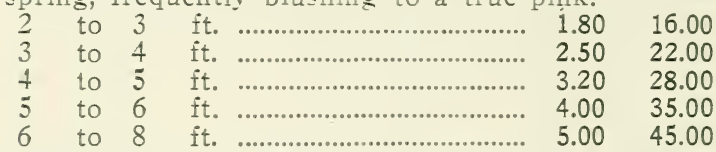

D. lemoinei (Lemoine Deutzia). 4 to $5 \mathrm{ft}$. Thite flowers in June in large clusters.
15 to 18
in.
2.00
18 to 24 in.
2.50

D. scabra crenata rosea plena (Double Pink Deutzia). 6 to 8 ft. Beautiful in June, with fragrant pink blossoms.

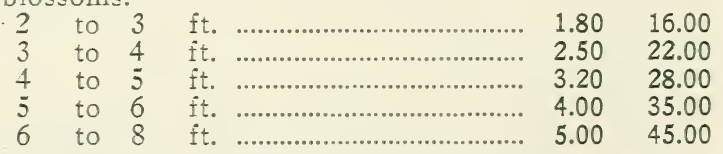

ELAEAGNUS angustifolia (Russian Olive). 15 to $18 \mathrm{ft}$. Orange berries against silvery foliage. Good for seashore.

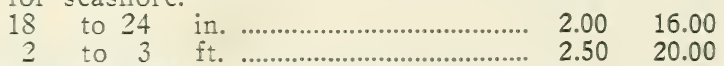

ENKIANTHUS campanulatus (Red Tein Enkianthus). 20 to $25 \mathrm{ft}$. Handsome erect shrub of great ornamental value. Excellent when associated in plantings with broadleaved evergreens.

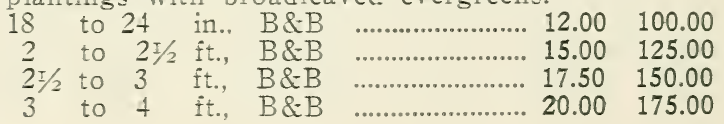


Hardy Shrubs-Contimued

$10 \quad 100$

EUONYMUS alatus (Winged Euonymus). 9 to 10 ft. A lovely sight in the fall with its red berries contrasting beautifully with the rosy-pink of its foliage.

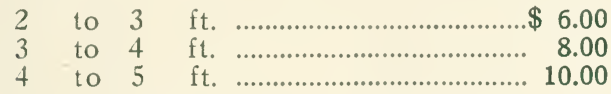

E. alatus compacta (Dwarf Winged Euonymus). 4 to $5 \mathrm{ft}$. Compact, dwarf form of above; ideal for a low wide hedge.

2 to $3 \mathrm{ft}$. ................................ 9.00

EXOCHORDA grandiflora (Pearlbush). 6 to $8 \mathrm{ft}$. Dazzling white flowers in May, from buds like pearls.

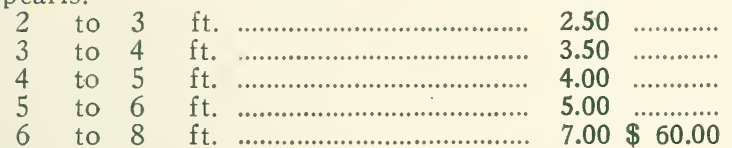

FORSYTHIA intermedia (Border Forsythia). 6 to $8 \mathrm{ft}$. A particularly hardy Forsythia with a mass of golden bloom in very early spring.

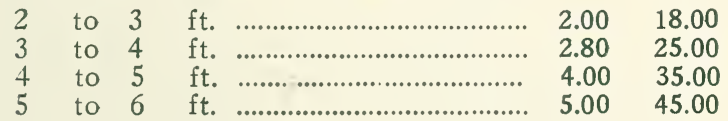

F. int. spectabilis (Showy Border Forsythia). 6 to $8 \mathrm{ft}$. Best and most beautiful of the family with more and bigger flowers than any other Forsythia with which we are familiar.

\begin{tabular}{|c|c|c|}
\hline to 24 & in & 1.70 \\
\hline to 3 & $\mathrm{ft}$. & 2.20 \\
\hline to & ft. & 2.80 \\
\hline to & 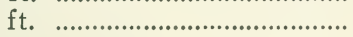 & 4.00 \\
\hline to & 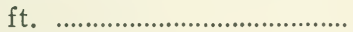 & 5.00 \\
\hline
\end{tabular}

F. suspensa (Weeping Forsythia). 4 to $5 \mathrm{ft}$. Indispensable for holding banks, and most graceful if allowed to hang over a. retaining wall. Carries masses of golden flowers on arching branches in April and May.

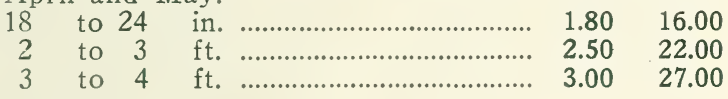

F. suspensa fortunei (Fortune Forsythia). 6 to $8 \mathrm{ft}$. A very robust, upright growing, dependable variety.

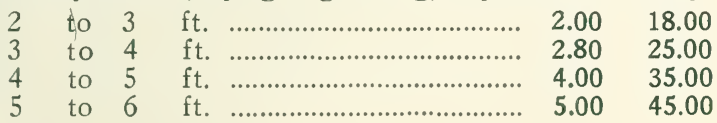

F. suspensa variegata (Goldblotch Forsythia). 7 to $8 \mathrm{ft}$. A most unusual and beautiful sort, with lemon yellow flowers in late spring, and golden leaves throughout the spring and summer.

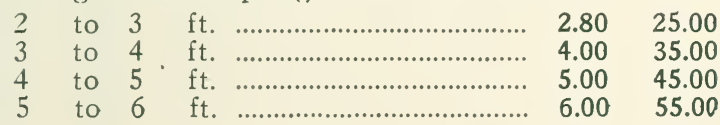


HARDY SHRUBS-Continued

FORSYTHIA-Concluded

$10 \quad 100$

F. viridissima (Greenstem Forsythia). 7 to $8 \mathrm{ft}$. Last of the species to flower, with green bark and thick, deep green leaves.

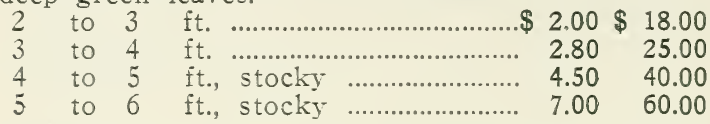

HAMAMELIS vernalis (Vernal Witch-hazel). 4 to $6 \mathrm{ft}$. Fragrant, pale yellow flowers mature in January, opening and closing with warm and cold spells. $\begin{array}{rrr}18 & \text { to } & 24 \\ 2 & \text { to } & 3 \\ 3 & \text { to } & 4 \\ 4 & \text { to } & 5 \\ 5 & \text { to } & 6 \\ 6 & \text { to } & 8\end{array}$

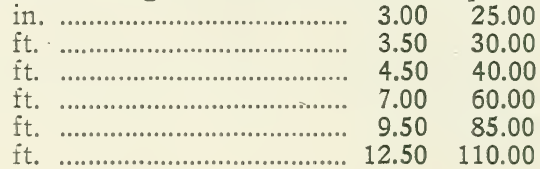

H. virginica (Witch-hazel) 10 to 12 ft. Flowers like golden ribbons in late fall. Best in moist shade.

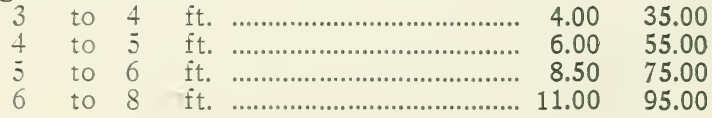

HIBISCUS syriacus. (Althaea or Rose of Sharon). 10 to $12 \mathrm{ft}$. Upright bushes with large, colorful flowers in late summer.

Anemonaeflora. Dbl. pink. (a) (b) (c) (d) (e) (f). Ardens. Dbl. rose-violet. (a) (b) (c) (d) (e) (f). Boule de Feu. Dbl. red. (a) (b) (c) (d) (e). Jeanne d'Arc. Dbl. white. (a) (b) (c) (d). Lucy. Dbl. crimson-purple. (a) (b) (c) (d) (e) (f). Purpurea semi-pleni. Semi-dbl. purple. (a) (b) (c) (d) (e) (f).

The Banner. Double white, prominently striped crimson. (a) (b) (c).
$\begin{array}{ll}\text { (a) } 18 & \text { to } 24 \\ \text { (b) } 2 & \text { to } 3\end{array}$
in.
$1.60 \quad 14.00$
(c) 3 to 4
(d) 4 to 5
ft. ............................... 2.20
ft. ............................. 2.80

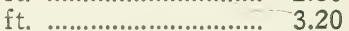
18.00
(e) 5 to 6
28.00
(f) 6 to 8
ft.
$4.50 \quad 40.00$

HIBISCUS syriacus (Althaea or Rose of Sharon). Coelestis. Sgl. blue.

Rubis. Sgl clear red. (a) (b) (c) (d).

Snowdrift. Sgl. white. (a) (b) (c).

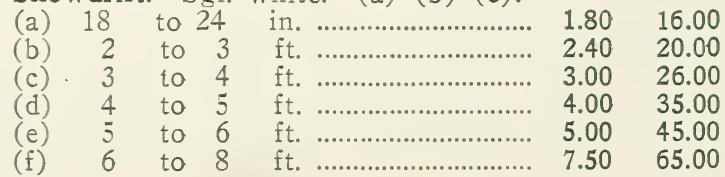

H. folio-variegata (Variegated-leaved Rose of Sharon). $8 \mathrm{ft}$. The foliage of this variety is very attractive, being blotched cream and white. The chocolatecolored flowers are rather small.

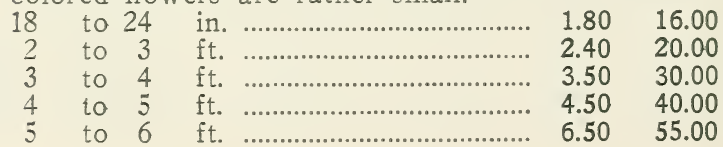


HARDY Shrubs-Continued

$10 \quad 100$

HYDRANGEA aborescens grandiflora (Snowhill Hydrangea). 4 to $5 \mathrm{ft}$. A familiar, but always beautiful sight with its great round white flower heads in late summer.

$$
\begin{aligned}
& 2 \text { to } 3 \mathrm{ft} \text {. } \\
& \$ 3.50 \$ 30.00
\end{aligned}
$$

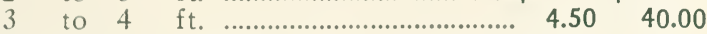

H. paniculata grandiflora (Peegee Hydrangea). 8 to 9 ft. Extremely popular, with showy conical flower heads, frequently a foot in length; pure white at first, but turning to pink and then to bronze and green.

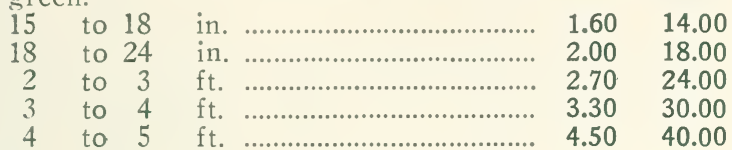

H. PANICULATA GRANDIFLORA (Standard or Tree Form). Beautiful specimens.

3 to $4 \mathrm{ft}$. stems

10.00

HYPERICUM aur€um (Golden St. Johnswort). 3 to $4 \mathrm{ft}$. Brilliant yellow flowers with numerous silky stamens in July and August. Will thrive in dry, rocky places.

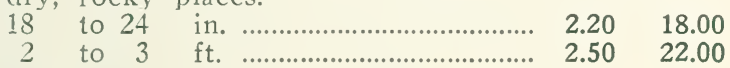

H. vanfleeti (Van Fleet St. Johnswort). 3 to $4 \mathrm{ft}$. Golden flowers in mid-summer form a particularly lovely picture against the blue-green foliage.
18 to 24
in.
$3.50 \quad 30.00$
2 to $3 \mathrm{ft}$
$4.50 \quad 40.00$

ILEX crenata (Japanese Holly). 8 to $10 \mathrm{ft}$. Good shrub or hedge plant, with evergreen, boxwood-like leaves and black berries.
18 to 24 in., B\&B
2 to $21 / 2 \mathrm{ft}$., $B \& B$
15.00
$21 / 2$ to $3 \mathrm{ft}$., $B \& B$
20.00
27.50

I. crenata convexa (bullata). (Convex leavied Holly). 4 to $5 \mathrm{ft}$. Of rather slow but sturdy growth, with roundish convex boxwood-like evergreen foliage. Extremely hardy and splendid for planting with other broad-leaf evergreens, also as a hedge.
15 to 18 in., $\mathrm{B} \& \mathrm{~B}$
18 to 24 in., $\mathrm{B} \& \mathrm{~B}$
12.50
2 to $21 / 2$ ft., $B \& B$
17.50
25.00

I. glabra (Inkberry). 5 to $6 \mathrm{ft}$. Dark evergreen leaves, turning purplish in winter, at which time its glistening black berries are particularly attractive.

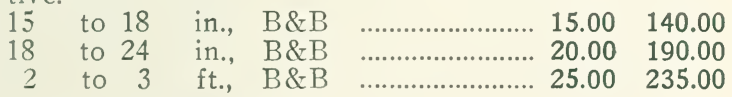

J. opaca. See page 45 .

I. verticillata (Common Winterberry). 6 to $8 \mathrm{ft}$. A native shrub that carries deep red berries until February. Succeeds in both swampy and dry soil. From every viewpoint a splendid variety.

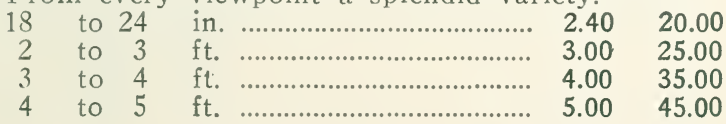


HARDY SHRUBS-Continued

KALMIA latifolia (Mountain-Laurel). 6 to $\tau \mathrm{ft}$. Most attractive pink flower clusters in June, and rich dark evergreen foliage continuously throughout the year. Unquestionably the most valuable of our native evergreen shrubs.
Clumps, 15
to 18
in., $B \& B$
Clumps, 18
to 24
in., $\mathrm{B} \& \mathrm{~B}$
$\$ 12.50 \$ 110.00$
Clumps, 2
to 3 it., $B \& B$
$15.00 \quad 135.00$

KERRIA japonica $f$ pl. (Double Kerria) 4 to 5 it Rich golden globe-shape flowers in May and irequently again in late summer.

15 to 18 in. ...................................... $2.50 \quad 3.50 \quad 30.00$

KOLKWITZIA amabilis (Beautybush). 5 to $6 \mathrm{ft}$. In June the graceful arching branches of this shrub are covered with dainty pink, bell-shaped flowers. 18 to 24 in. ....................................... $3.50 \quad 30.00$ 2 to 3 ft. ...................................... $4.50 \quad 40.00$

LESPEDEZA bicolor (Bushclover). 5 to $6 \mathrm{ft}$. Rosypurple flowers, like small Sweet Peas, almost envelop the foliage in late summer.

3 yrs. extra fine ........................................ 3.00

LEUCOTHOE catesbaei (Drooping Leucothoe) 3 to $4 \mathrm{ft}$. Attractive, fragrant white flowers in May and handsome, lustrous evergreen foliage which colors up beautifully in autumn.

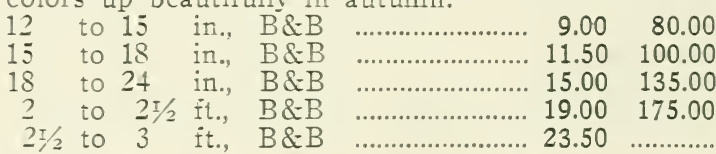

\section{LIGUSTRUM (Privet)}

\section{(The Most Popular of All Hedge Plants)}

Each year we grow from two million to three million sturdy, beautifully rooted plants of California Privet. Some peaple declare we are the largest growers of Privet in the World. We do not know whether or not that is true, but we do know that better Privet can not be grown than that which we produce.

LIGUSTRUM amurense (Amur River North Privet). 12 to $15 \mathrm{ft}$. Upright growing, with olive green leares. Best hedge plant for serere climates. being the hardiest of any Privet.

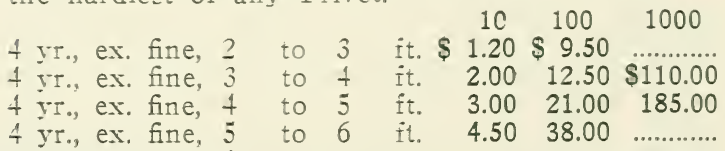

L. ibolium (Ibolium Priret), 8 to $10 \mathrm{it}$. The beauty of California Privet, and the hardiness of Ibota, combine to make this an ideal hedge plant.
12 to 18
$.70 \quad 5.50$
18 to 24
in.
55.00

L. ibota (Ibota Privet). 9 to 10 ft. A very hardy exceedingly dense hedge plant with black berries. Also frequently used as an ornamental shrub.

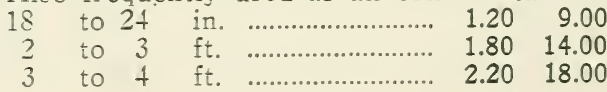


HARDY SHRUBS-Continued

$10 \quad 100 \quad 1000$

L. ovalifolium (California Privet), 8 to $10 \mathrm{ft}$. Over a half century ago California pr svet was introduced as a Hedge plant by the founder of this business, and at the present time, it is probably the most popular Hedge plant in this country. Although we are growing these valuable plants most economically, all of them are bushy, sturdy and of the highest quality.

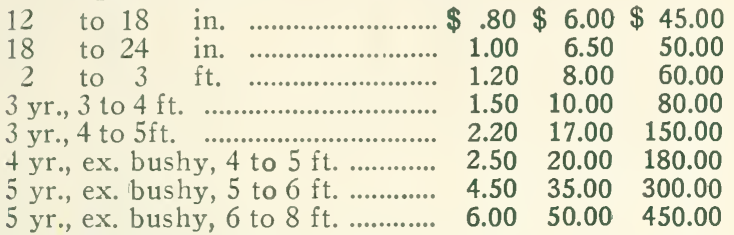

L. ovalifolium aureum (Golden Privet). 8 to $9 \mathrm{ft}$. Slow growing, golden leaved form of California privet.
2 to $3 \mathrm{ft}$.
$3.50 \quad 30.00$

\section{Globe or Ball Privet, also Pyramids}

The foliage of these splendid, compact plants resembles that of finely grown Boxwood.

Globe, or Ball California Privet

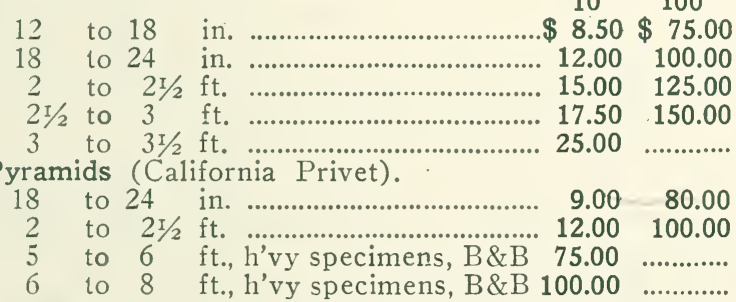

L. regelianum (Regal Privet). 5 to $6 \mathrm{ft}$. Because this spreading Privet thrives where smoke and dust are present, makes it very popular for city plantings. Also invaluable for shrub groupings, and a splendid sort for producing a fairly low, compact hedge.

\begin{tabular}{|c|c|c|c|c|c|c|}
\hline & & & & 10 & 100 & 1000 \\
\hline 12 & to 18 & in. & 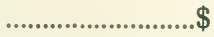 & 1.80 & $\$ 16.00$ & $\$ 140.00$ \\
\hline & to 24 & in. & .............................. & 2.80 & 25.00 & 220.00 \\
\hline & to $21 / 2$ & in. & …………………...... & 3.50 & 30.00 & \\
\hline & to & ft. & 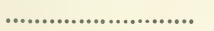 & 4.50 & 40.00 & \\
\hline & 10 & $\mathrm{ft}$. & 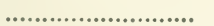 & 5.50 & 50.00 & \\
\hline
\end{tabular}

I wish to compliment you on the fine Privet you shipped me last Fall, and the prompt service. FRED J. SCHMIDT, Dresher, $\mathrm{Pa}$.

LONICERA bella albida (White belle Honeysuckle). 8 to $9 \mathrm{ft}$. A vigorous grower, with blue-green foliage on purplish-brown branches. Produces many white flowers in early spring, followed by red berries.

2 to $3 \mathrm{ft}$

3 to $4 \mathrm{ft}$. 


\section{HARDY SHRUBS-Continued}

LONICERA-Concluded

L. fragrantissima (Winter Honeysuckle). 6 to $7 \mathrm{ft}$. Popular, with highly perfumed white flowers in very early spring, before the leaves appear.
2 to $3 \mathrm{ft}$.

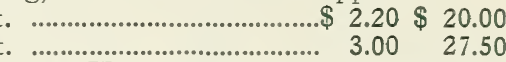

3 to $4 \mathrm{ft}$.

L. morrowi (Morrow Honeysuckle). 7 to $8 \mathrm{ft}$. Of spreading habit, with white flowers in May and June followed by either red or yellow fruits.

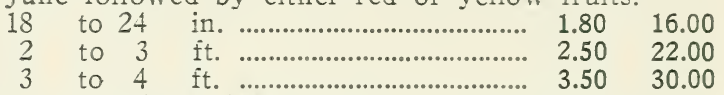

L. ruprechtiana (Manchurian Honeysuckle). 8 to $9 \mathrm{ft}$. Creamy white flowers in June followed by red berries.

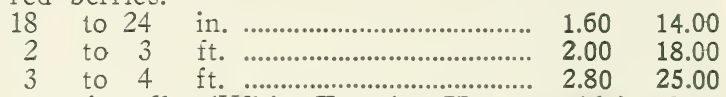

L. tatarica alba (White Tatarian Honeysuckle). 9 to $10 \mathrm{ft}$. Similar to following varieties except color of flowers which are white.
2 to 3
ft.
2.00
3 to $t$ ft.
2.80

L. tatarica rosea (Rosy Tatarian Honeysuckle). 9 to $10 \mathrm{ft}$. An old favorite, with lovely rosy-pink flowers in late May, and red berries from midsummer until frost.

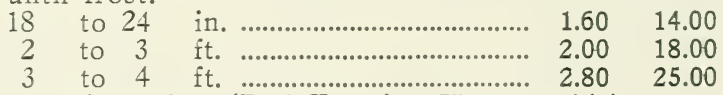

L. tatarica rubra (Red Tatarian Honeysuckle). 9 to $10 \mathrm{ft}$. Similar to the above variety except for color of flowers, which are an attractive red.
18 to 24
$1.60 \quad 14.00$
2 to 3 ft. ....................................... 2.00 18.00
3 to 4 ft. ..................................... $2.80 \quad 25.00$

OXYDENDRUM arboreum (Sourwood). See DECIDUOUS TREES, page 39.

PHILADELPHUS coronarius (Sweet Mockorange). 9 to $10 \mathrm{ft}$. Deliciously fragrant white flowers in May and June, reminding one of Orange Blossoms.

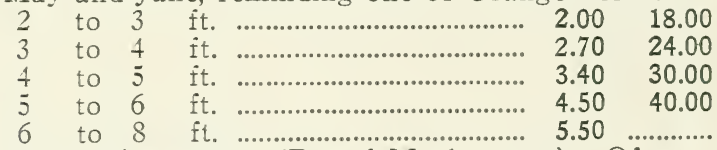

P. coronarius aureus (Dwarf Mockorange). Of very dwarf growth, with bright gold foliage.

9 to 12 in. ....................................... 2.00

12 to 15 in. ..................................... 2.50 $8 \mathrm{ft}$. The lovely glistening white, extra large floters, produced by this variety, are quite lacking in fragrance.

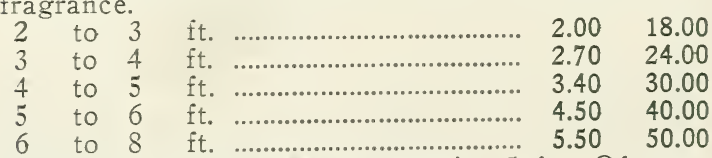

P. lemoinei (Lemoine Mockorange). $5 \mathrm{ft}$. Of compact growth with small leaves. In May it carries an abundance of small, attractive, fragrant white flowers.
18 to 24
2.50
20.00
2 to 3
in. 
Hardy Shrubs-Continued

10100

P. Mont Blanc (White Mountain Mockorange). 4 to $5 \mathrm{ft}$. Useful hybid with dazzling white June flowers. A vigorous sort.

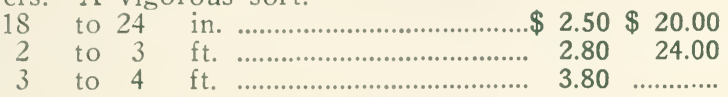

P. nivalis (Snowbank Mockorange). 6 to $7 \mathrm{ft}$. Very much like the Big Mockorange, but of spreading growth.

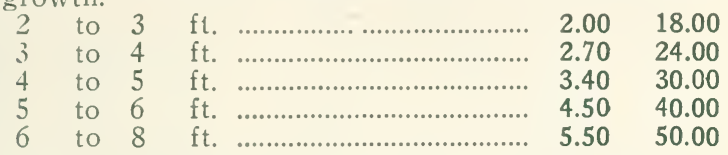

P. virginalis (Virginal Mockorange). 7 to $8 \mathrm{ft}$. Best of the family, with highly fragrant, large, single and semi-double flowers in large clusters throughout the summer.

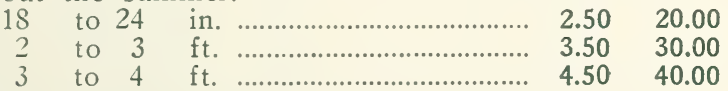

PHOTINIA villosa (Christmas Berry). 12 to $15 \mathrm{ft}$. Bright red berries among autumnal foliage which is nearly as red as the berries, themsleves.

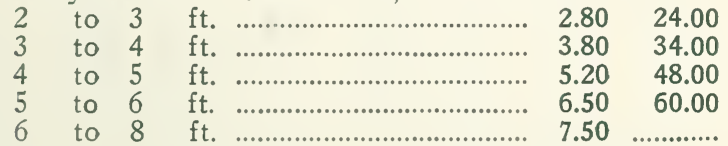

PHYSOCARPUS opulifolius (Common Ninebark). 9 to $10 \mathrm{ft}$. Good in full sull or shade, with creamy June flowers.

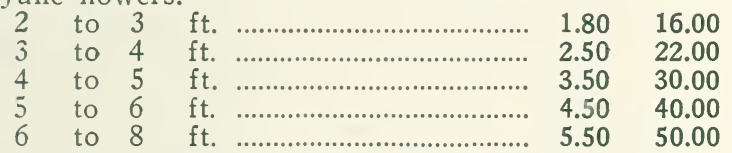

P. opulifolius aureus (Goldleaf Ninebark). 9 to $10 \mathrm{ft}$. Flowers like above; but foliage is golden yellow.

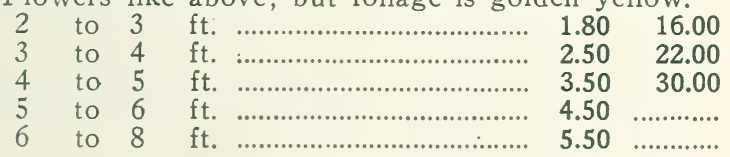

PIERIS floribunda (Mountain Andromeda). $4 \mathrm{ft}$. Evergreen, with its waxy white May flowers outstanding against the background of dark green foliage. Best in acid soil.
12 to 15 in., $\mathrm{B} \& \mathrm{~B}$
15 to 18 in. $B \& B$
15.00
20.00
18 to 24 in., $\mathrm{B} \& \mathrm{~B}$........................ 27.50

P. japonica (Japanese Andromeda). 5 to $6 \mathrm{ft}$. Another lovely evergreen shrub with pendants of pure white flowers against the shining green foliage in early spring.

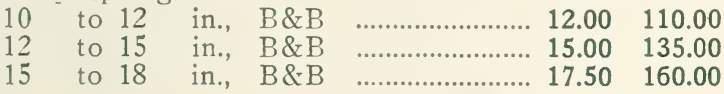




\section{HARDY SHRUBS-Continued}

10100

PRUNUS glandulosa (Double Pinkflowering A1mond). 4 to $5 \mathrm{ft}$. Beautiful double pink flowers in early spring almost envelop the branches.

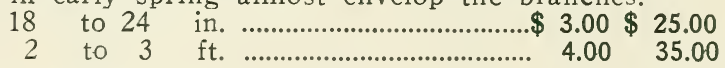

P. maritima (Beach Plum). 8 to $10 \mathrm{ft}$. Many delicate white blossoms appear on bare stiff branches early in the spring. Good for seashore. The fruit makes most delicious jelly.
15 to 18
18 to 24
in.
3.50
25.00
in.
4.00
30.00
2 to 3
t. .............................................. 5.00
40.00

P. triloba plena (Double-flowered Plum). 7 to $8 \mathrm{ft}$. Bright pink flowers, larger and more colorful than those of the Flowering Almond, are thick on the slender branches in the spring.
2 to 3
$\mathrm{ft}$.
4.00
3 to 4
5.00

PYRACANTHA coccinea lalandi (Firethorn). 15 to $18 \mathrm{ft}$. Orange-red berries stand out beautifully against deep green foliage. Best trained against the wall, but also makes a beautiful "specimen" shrub.
2 to 3 ft., $B \& B$
3 to 4 ft., $B \& B$
4 to 5 ft., $B \& B$
5 to 6 ft., $B \& B$
20.00
30.00
45.00
60.00

RHAMNUS cathartica (Common Buckthorn). 10 to $12 \mathrm{ft}$. Dark green leaves, black fruit. Valuable for background planting.

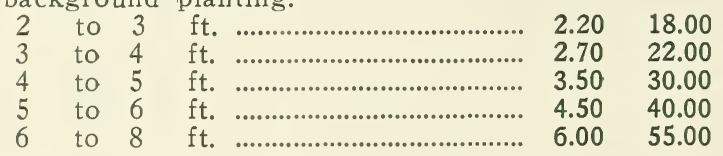

R. frangula (Glossy Buckthorn). 8 to $9 \mathrm{ft}$. Dense, shining foliage and red berries which mature black.

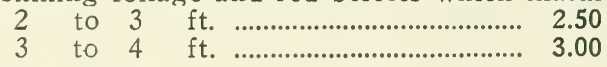

RHODODENDRON carolinianum (Carolina Rhododendron). 5 to $6 \mathrm{ft}$. Floral bells of brightest pink appear in late spring among the evergreen leaves of this lovely native.

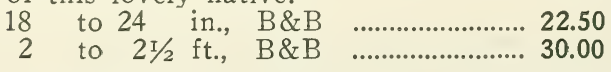

R. carolinianum minus (Dwarf Carolina Rhododendron). 3 to $4 \mathrm{ft}$. A slow growing form of the above.

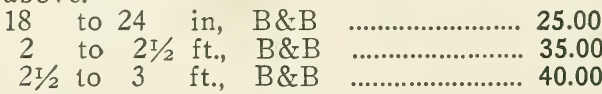

R. catawbiense (Catawba Rhododendron). 6 to $9 \mathrm{ft}$. Big, rosy purple flowers in May and June.

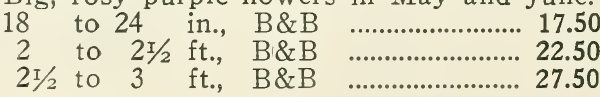


HARDY Shrubs-Continued

10100

RHODODENDRON HYBRIDS. All grafted from choicest named sorts.

Album Elegans. White flushed pink. (a) (b) (c). Catawbiense album. Clear white. (a) (b).

Catawbiense grandiflora. Lavender. (a) (b).

Delicatissima. Blush. (a) (b) (c).

Dr. H. C. Dresselhuys. Bright red. (a) (b).

Ignatius Sargent. Deep rosy scarlet. (a) (b),

Lees Dark Purple. Deep purple. (a) (b).

Mrs. C. S. Sargent. Pink, yellow eye. (a) (b).

President Lincoln. Rich pink. (a) (b).

Roseum Elegans. Bright rose-pink. (a) (b).
(a) 15 to 18 in., B\&B
$\$ 22.50$
(b) 18 to 24 in., $B \& B$
(c) 2 to $2 \frac{1}{2} \mathrm{ft}$., $B \& \mathrm{P}$
32.50
42.50

R. Hybrids. Mixed colors. Well grown shapely plants at bargain prices.
18 to 24 in., $B \& B$
25.00
2 to $2 \mathrm{~T} / 2 \mathrm{ft}$., $\mathrm{B} \& \mathrm{~B}$
32.50
$2 \mathrm{~T} / 2$ to 3 ft., $B \& B$
42.50
3 to $4 \mathrm{ft}$., $\mathrm{B} \& \mathrm{~B}$
52.50

R. maximum (Rosebay Rhododendron). 8 to $12 \mathrm{ft}$. Extra selected plants, with a maximum of pink flowers in late May and June.
18 to 24 in., $\mathrm{B} \& \mathrm{~B}$
$13.50 \$ 125.00$
2 to $3 \mathrm{ft}$., $\mathrm{B} \& \mathrm{~B}$
3 to 4 ft., $B \& B$
$20.00 \quad 185.00$
4 to 5 ft., $B \& B$
$30.00 \quad 290.00$
$40.00 \quad 385.00$

RHODOTYPOS kerrioides (Jetbead). $5 \mathrm{ft}$. White flowers of four petals in May, followed by shiny black berries persistent until winter.
18
2 to 24
to 3
in.
2.50
3.50

RHUS canadensis (Fragrant Sumach). 4 to $5 \mathrm{ft}$. Shiny yellow flowers in clusters, followed by coralred globules in early summer. Brilliant orangescarlet fall foliage, sweetly aromatic.
2 to $3 \mathrm{ft}$.
3.50
3 to $4 \mathrm{ft}$.
4.50

R. cotinus (Smoketree). 12 to $15 \mathrm{ft}$. Not only an attractive specimen when it carries a great mass of filmy purplish flower clusters in July, but attractive continuously from early spring until freezing weather, because its flat round leaves are stained pink when young and are of yellow and purple tones in autumn.

\begin{tabular}{|c|c|c|c|c|}
\hline & & & & \\
\hline to & 3 & ft. $\ldots . . . . . . . . . . . . .$. & 4.20 & 38.00 \\
\hline & 4 & 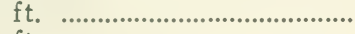 & 6.00 & 55. \\
\hline & 5 & ........ & 8.00 & 75.00 \\
\hline & 6 & . & 12.50 & 100. \\
\hline & & 21 & 17.50 & \\
\hline
\end{tabular}

ROSA hugonis (The Golden Rose of China). 5 to 6 ft. Clear yellow flowers cover the handsome shrub in early May and its lovely fern-like foliage is lovely throughout the entire summer. We have, this season, a splendid supply.
15 to 18
in.
$2.50 \quad 20.00$
3 to 4
ft.
$5.00 \quad 45.00$

R. humilis (Pasture Rose). $3 \mathrm{ft}$. Charming pink single roses, in June. One of the best of our "wild" Roses.
18 to 24
in.
2.50
20.00
2 to 3
ft.
$3.50 \quad 30.00$ 
HARdy Shrubs-Continued

ROSA-Concluded

10100

R. lucida (Virginia Rose). $6 \mathrm{ft}$. Large shining leaves, and many rose-pink flowers lasting into July.
12 to 18
in.
$\$ 1.60 \$ 14.00$
18 to 24
in.
2.00
18.00
2 to $3 \mathrm{ft}$

R. multiflora japonica (Japanese Rose). 8 to $10 \mathrm{ft}$. Good in mass; big clusters of white flowers in June and many bright red berries in fall and early winter. Best of all understocks for named Roses.

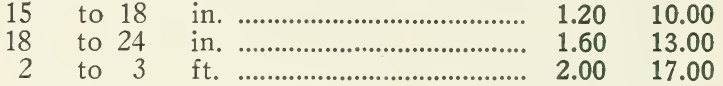

\section{Rosa Multiflora Japonica Seedlings}

All carry good straight stems and are beautifully rooted.

2 to 3 mm. .......\$7.00 $\begin{array}{cc}1000 & 10,000 \\ \$ 6.00 \text { per } M\end{array}$

R. nitida (Pasture Rose). 2 to $3 \mathrm{ft}$. Fragrant deep pink single flowers, glossy green foliage. Splendid for naturalistic plantings.

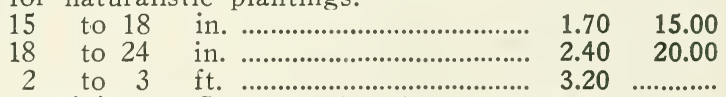

R. rubiginosa (Sweetbrier). $6 \mathrm{ft}$. Bears a mass of rich, deep pink flowers in June and foliage is highly aromatic.

3 to 4 ft., extra heavy ................ $3.20 \quad 28.00$

4 to 5 ft., extra heavy ................... $4.20 \quad 37.00$

R. rugosa (Rugosa Rose). 4 to $5 \mathrm{ft}$. Resistant to salt air; with many exceptionally large, single, fragrant pink flowers throughout the summer months, followed by large red and yellow hips (seed pods). Makes a splendid hedge.

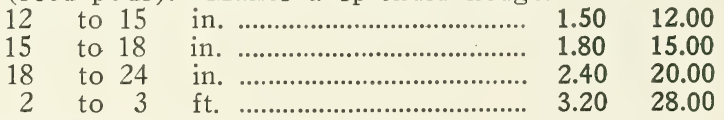

\section{Rosa Rugosa Seedlings}

Extra strong, 2 yrs. old.

$\$ 5.00$ per $100, \$ 40.00$ per 1000

R. setigera (Prairie Rose). 8 to $10 \mathrm{ft}$. Deep rosecolored flowers in early summer. Good for massing and for covering rocky slopes.

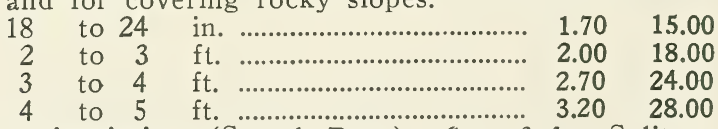

R. spinosissima (Scotch Rose). 2 to $3 \mathrm{ft}$. Solitary but numerous flowers, pink, white or yellow.

2 to $3 \mathrm{ft}$. 


\section{Hardy Shrubs-Continued}

$$
10100
$$

SALIX caprea (Pussy Willow). 15 to $20 \mathrm{ft}$. Fuzzy silvery gray spring buds on long, willowy branches.

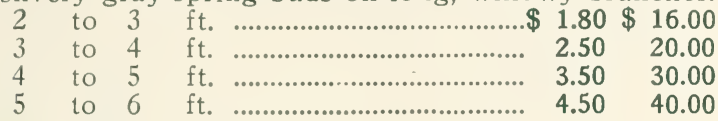

SAMBUCUS canadensis aurea (Golden Elder). 8 to $10 \mathrm{ft}$. Flat white flower heads from golden foliage in mid-summer.

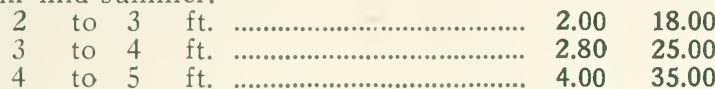

S. pubens (Scarlet Elder). 10 to $12 \mathrm{ft}$. Brilliant red berries in clusters in early summer. A splendid variety.

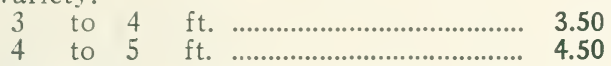

SORBARIA aitchisoni (Kashmir False-spirea). 4 to $5 \mathrm{ft}$. Graceful compound foliage; flowers creamywhite, July-Sept.

2 to 3 ft. ................................ $2.50 \quad 20.00$

3 to 4 ft. .................................. $3.50 \quad 30.00$

SPIRAEA Anthony Waterer (Waterer Spirea). $3 \mathrm{ft}$. Flat heads of rosy pink flowers are borne all summer on these popular compact shrubs.

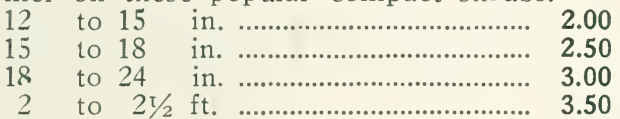

S. arguta (Garland Spirea). 5 to $6 \mathrm{ft}$. An exceptionally beautiful Spirea with a profuse bloom of white flowers in late spring, and with fine feathery attractive foliage.

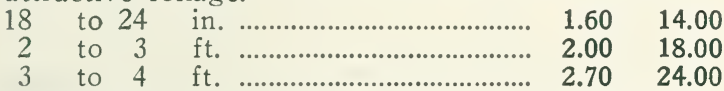

S. ariafolia (Ocean Spray). 6 to $7 \mathrm{ft}$. A familiar and beautiful sight on the West Coast with its many big, soft panicles of small, light tan flowers, in early summer.

3 to 4 ft. ............................... 7.00

S. billiardi (Billiard Spirea). 5 to $6 \mathrm{ft}$. Spikes of fluffy, bright pink flowers from July to October.
2 to $3 \mathrm{ft}$
$1.80 \quad 16.00$
3 to $4 \mathrm{ft}$
ft.
4 to 5 ft. .................................. $3.30 \quad 30.00$

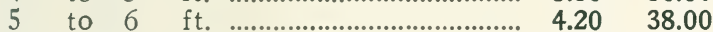

S. froebeli (Froebel Spirea). $4 \mathrm{ft}$. Flowers in early summer like those of Anthony Waterer, but slightly lighter in color.

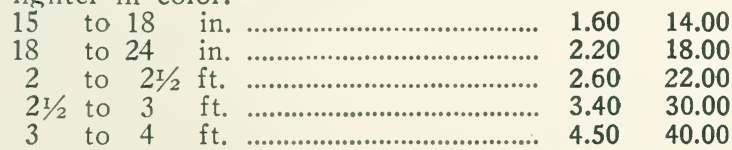

S. japonica (Japanese Spirea) (Spirea callosa alba). $3 \mathrm{ft}$. The many white flowers, which are borne in early summer, stand out well against the purplish foliage of these plants when young.

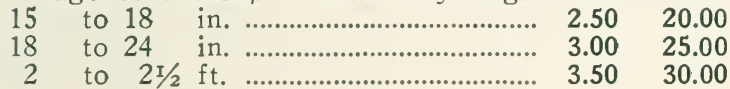


HARDY SHRUBS-Continued

SPIRAEA-Concluded

$10 \quad 100$

S. prunifolia fl. pl. (Bridalwreath). 7 to $8 \mathrm{ft}$. Tiny double, buttonlike white spring flowers by the thousand. The original, and always beautiful, Bridalwreath.

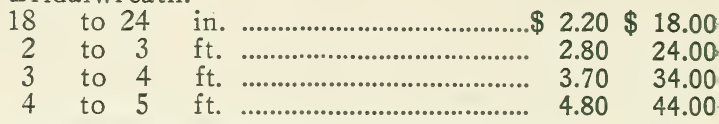

S. richmensis (Improved Douglas Spirea). $5 \mathrm{ft}$. Broad spikes of bright pink flowers among graceful foliage. 2 to 3 ft. ....................................... 2.00 18.00

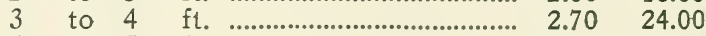
4 to 5 ft. ........................................ $3.50 \quad 33.00$ 5 to $6 \mathrm{ft}$............................................ $4.60 \quad 42.00$

S. thunbergi (Thunberg Spirea). 4 to $5 \mathrm{ft}$. White flowers in spring, and attractive yellow-green lacelike foliage which turns red and orange in the fall.
18 to 24
2 to $2 \mathrm{r} / 2 \mathrm{ft}$.
$1.80 \quad 16.00$
$2 \mathrm{I} / 2$ to $3 \mathrm{ft}$
$2.40 \quad 20.00$

S. trichocarpa (Korean Spirea................ $3.00 \quad 26.00$ ingly beautiful snow-white flowers in late June weigh down this spreading bush and make it outstanding in any shrub collection.

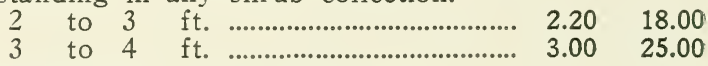

S. vanhouttei (Vanhoutte Spirea). 7 to $8 \mathrm{ft}$. Most popular of all flowering shrubs, with its masses of lovely white flowers on pendulous branches in late spring.

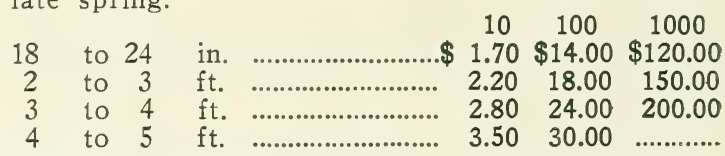

STEPHANANDRA flexuosa (Cutleaf Stephanandra). 5 to $6 \mathrm{ft}$. The attractive finely cut foliage of this sort renders it an outstanding variety either for use as a specimen shrub or as a hedge plant.

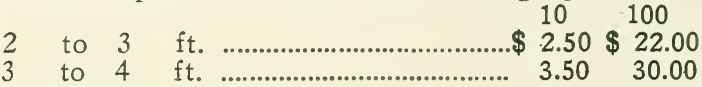

SYMPHORICARPOS chenaulti (Chenault Snowberry). $5 \mathrm{ft}$. Pink and white fruits among dense twiggy branches in the fall. Its great mass of small bright green leaves also add to its attractiveness.
18 to 24
in.
$1.60 \quad 14.00$
2 to 3
ft.
$2.00 \quad 18.00$

S. mollis (Spreading Snowberry). 6 to $7 \mathrm{ft}$. Many white persistent berries in late summer and early fall.

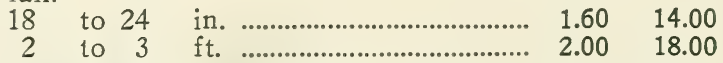

S. racemosus (Snowberry). 4 to $5 \mathrm{ft}$. Big, round white berries load down the slender branches in late summer. Popular.

18 to 24 in. ......................................... $1.60 \quad 14.00$

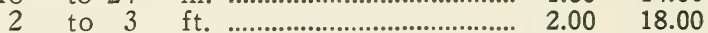

S. vulgaris (Coralberry). 4 to $5 \mathrm{ft}$. Good for natural plantings, with numerous bright coral berries.
18 to 24
in.
$1.60 \quad 14.00$

2 to 3

ft.

$2.00 \quad 18.00$ 
HARDY SHRUBS-Continued

$10 \quad 100$

SYMPLOCOS paniculata (Turquoise Berry), 20 to $25 \mathrm{ft}$. White flowers in spring followed by turquoise blue berries in autumn. Does best in well drained soil.
18 to 24
in.
$\$ 3.50$
2 to 3
$\mathrm{ft}$.
4.50

Your special shrub offer, sent me last Fall, was very satisfactory in every particular.

\section{FRANK B. HEADLEY, Prop., Pataskala Nursery \& Floral Co., Pataskala, Ohio.}

SYRINGA chinensis (Rothomagensis) (Chinese Lilac). 12 to $15 \mathrm{ft}$. The slender branches of this attractive variety terminate, in late spring, in compact clusters of rich, purple-lilac flowers.

\begin{tabular}{|c|c|c|}
\hline to 24 & (1) & \\
\hline to 3 & 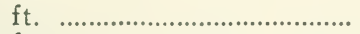 & $2.8-1-v-1-10$ \\
\hline $\begin{array}{l}4 \\
5\end{array}$ & 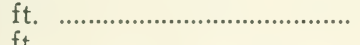 & 3.8 \\
\hline
\end{tabular}

S. japonica (Japanese Tree Lilac). 18 to $20 \mathrm{ft}$. Panicles of creamy white flowers. Blooms in early summer. Actually a dwarf tree.
3 to 4 ft.
5.00
4 to $5 \mathrm{ft}$.
6.50

S. persica (Persian Lilac). 8 to $10 \mathrm{ft}$. Fragrant pale lilac flowers, loosely arranged.
2 to $3 \mathrm{ft}$.
$3.20 \quad 28.00$
3 to 4 ft. ............................................ $4.20 \quad 38.00$

S. persica alba (White Perșian Lilac). 9 to $10 \mathrm{ft}$. Free bloomer with attractive white flowers.
3 to $4 \mathrm{ft}$.
$5.00 \quad 45.00$
4 to 5
ft.
$6.50 \quad 60.00$
5 to 6
$\mathrm{ft}$.
$8.50 \quad 75.00$

S. villosa (Late Lilac). 7 to $8 \mathrm{ft}$. Pinkish lilac flowers in June after most other Lilacs have passed out of bloom.
18 to 24
in.
$\begin{array}{ll}1.80 & 16.00\end{array}$
2 10 3
$\mathrm{ft}$.
$2.50 \quad 22.00$
$3.50 \quad 30.00$

S. vulgaris (Purple Lilac). 12 to $15 \mathrm{ft}$. Sweetly fragrant old favorite, with deep purple flower heads in May.
18 to 24
in.
2.00
18.00
2 to 3
ft.
$2.70 \quad 24.00$
4 to 5
$\mathrm{ft}$.
$3.70 \quad 34.00$

S. vulgaris alba (White Lilac). 12 to $15 \mathrm{ft}$. Whiteflowered form of above.
18 to 24
2 to 3
in.
2.50
22.00
3 to 4
$\mathrm{ft}$.
$3.50 \quad 32.00$
$4.50 \quad 42.00$ 
HARdy Shrubs-Continued

SYRINGA (Lilac)-Concluded

SYRINGA (Lilac). Choice named sorts:

Alphonse Lavelle. Double, lilac flowers.

(c) (d) (e).

(a) (b)

Belle de Nancy. Single, satiny pink, white center. (a) (b) (c) (d) (e).

Bleuatre. Single, light blue. (a) (b) (c).

Charles the Tenth. Single, rich purple-red. (b) (c) (d) (e).

Edouard Andre. Double, pink. (a) (b) (c).

Gen. Pershing. Double, light blue. (a) (b) (c) (d). Ludwig Spaeth. Single, reddish-purple. (a) (b) (c) (d).

Marc Micheli. Double blue. (a) (b) (c) (d) (e). Marie Le Graye. Single, pure white. (a) (b) (c) (d).

Marleyensis. Single. Lavender. (a) (b) (c) (d).

Michel Buchner. Double, clear, pinkish lilac. (a) (b) (c) (d) (e).

Mme. Abel Chatenay. Semi-double, yellowish white. (a) (b) (c) (d) (e).

Mme. Casimir-Perier. Double, creamy white.

(b) (c) (d).

Mme. Lemoine. Double, white. (a) (b).

President Carnot. Double, pale lilac. (a) (b) (c) (d).

President Grevy. Double, soft violet. (a) (b) (c). (d) (e).

President Lincoln. Single, blue. (a) (b) (c).

Rubra de Marley. Single, pale lilac-red. (a) (b) (c) (d).

Ruhm Von Horstenstein. Single, red to lilac. (a) (b) (c).

Vauban. Double, lilac. (a) (b) (c) (d) (e).

Volcan. Single, dark rose. (a) (b) (c) (d).

William Robinson. Double, red and purple. (b) (c).

(a) $15^{\text {to }} 18$

(b) 18 to 24

(c) 2 to 3

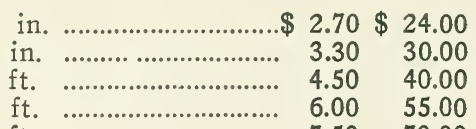

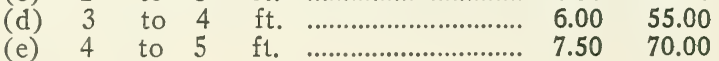

TAMARIX africana (African Tamarix). 12 to $14 \mathrm{ft}$. Pink flowers in spring from feathery gray foliage. Exceptionally good for seashore plantings.

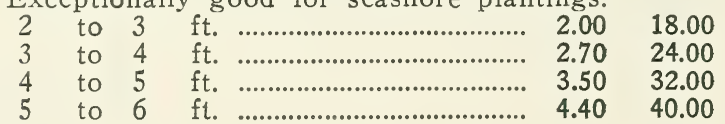

T. gallica (French Tamarix). 8 to $9 \mathrm{ft}$. An outstanding shrub with bluish green foliage and light pink flowers in the late summer.

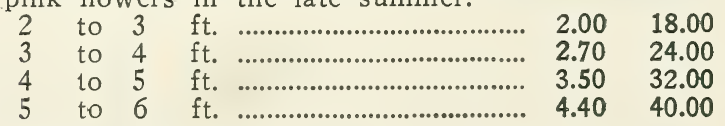

T. odessana (Odessa Tamarix). 5 to $6 \mathrm{ft}$. Pink flowers in August grace the glaucous foliage of this attractive sort.

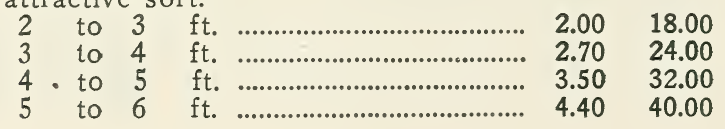


HARDY SHRUBS-Contimued

$10 \quad 100$

VACCINIUM corymbosum (Highbush Blueberry). 6 to $8 \mathrm{ft}$. The clusters of waxy white bell-shaped flowers are almost as beautiful as is the brilliant autumnal foliage.

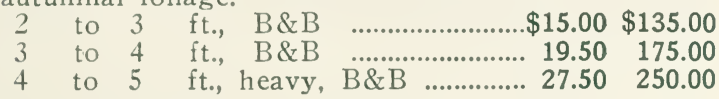

VIBURNUM americanum (Oxyococcos) (American Cranberry). 10 to $12 \mathrm{ft}$. Bright scarlet berries persist nearly all winter.

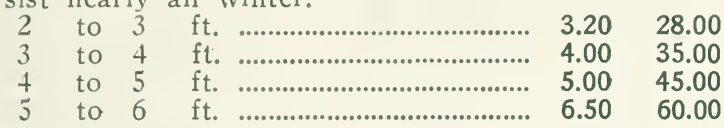

V. burkwoodi (Burkwood Viburnum). 4 to $5 \mathrm{ft}$. Very similar to the popular variety Viburnum carlesi, with equally fragrant flowers and declared to be even more hardy than that variety.
18 to 24 in., $\mathrm{B} \& \mathrm{~B}$
2 to 3 ft., $B \& B$
$20.00 \quad 175.00$
3 to 4 ft., $\quad$ B \&B $\quad$......................... $30.00 \quad 275.00$
$25.00 \quad 225.00$

V. carlesi (Fragrant Viburnum). 4 to $5 \mathrm{ft}$. Waxy pink, delightfully fragrant flowers bloom in small round clusters as the leaves are appearing. Prefers well drained sunny spot.
15 to 18 in., $\mathrm{B} \& \mathrm{~B}$
18 to 24 in., $B \& B$
2 to $21 / 2 \mathrm{ft}$., $B \& B$
$\begin{array}{ll}13.50 & 120.00\end{array}$
$16.00 \quad 145.00$
$18.00 \quad 165.00$

V. cassinoides (Withe-rod). $6 \mathrm{ft}$. Creamy white flowers in June, followed by blue berries.
18 to 24
in.
ft.
3.00

V. dentatum (Arrowwood). 10 to $12 \mathrm{ft}$. White flowers in late spring, and blue-black berries in summer. Fall foliage is red and purple.
18 to 24
$\begin{array}{lll}2 & \text { to } 3 \\ 3 & \text { to } & 4\end{array}$
in.
$\begin{array}{ll}1.80 & 16.00\end{array}$
ft.
$2.50 \quad 22.00$
$\mathrm{ft}$.
$3.20 \quad 28.00$

V. lantana (Wayfaring-tree). 15 to $18 \mathrm{ft}$. White flowers in May and June followed by red berries which slowly turn black in autumn, at which time the foliage colors brilliant red.

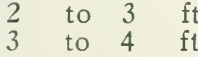
$2.50 \quad 22.00$
4 to 5
ft.
3.00
4.00

V. lentago (Nannyberry). $20 \mathrm{ft}$. White spring flowers, black summer berries, followed by a gorgeous foliage effect of crimson and purple.
$\begin{array}{lll}2 & \text { to } & 3 \\ 3 & \text { to } & 4 \\ 4 & \text { to } & 5 \\ 5 & \text { to } & 6 \\ 6 & \text { to } & 8\end{array}$

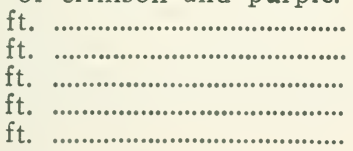
$3.50 \quad 30.00$
$4.50 \quad 40.00$
$5.50 \quad 50.00$
7.00
9.00

$\mathrm{V}$. opulus (European Cranberry). 8 to $9 \mathrm{ft}$. Big bunches of sizeable scarlet berries persist all winter.
2 to $3 \mathrm{ft}$.
3 to $4 \mathrm{ft}$.
$3.20 \quad 28.00$
4 to 5
ft.
$4.00 \quad 35.00$
5106
ft.
$5.00 \quad 45.00$
$6.50 \quad 60.00$ 


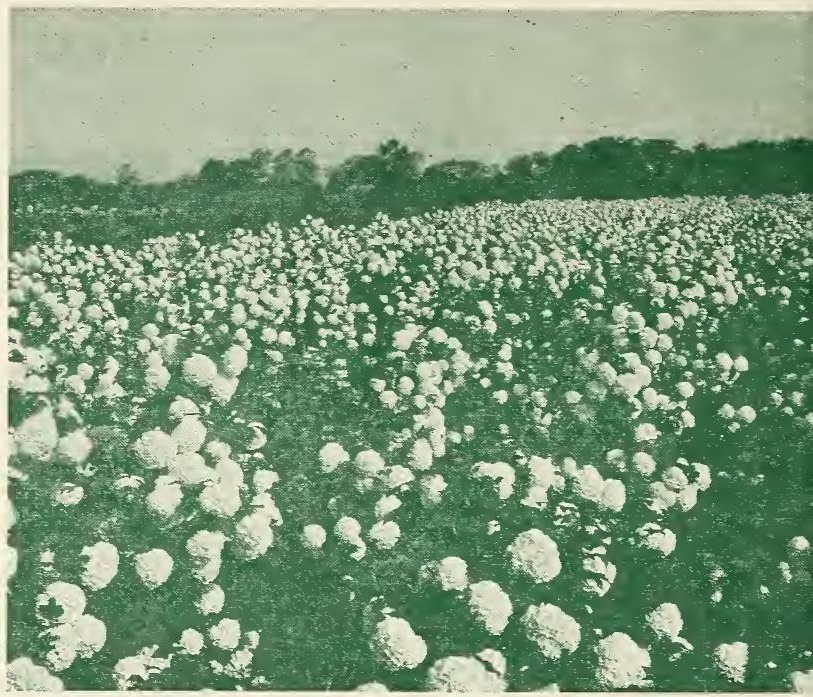

Viburnum Opulus Sterilis as we grow them

\section{HARDY SHRUBS-Continued}

\section{VIBURNUM-Concluded

V. dilatatum (Linden Viburnum). 8 to $10 \mathrm{ft}$. Large clusters of creamy white flowers and red berries which persist all winter.
3 to 4
ft.
$\$ 5.50$
4 to $5 \mathrm{ft}$
7.00

V. opulus sterile (Snowball). 9 to $10 \mathrm{ft}$. Popular, with big, round heads of white Snowball-like bloom in late spring.

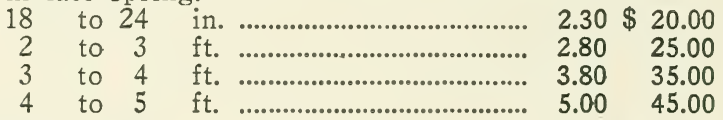

V. prunifolium (Blackhaw). $20 \mathrm{ft}$. Produces heads of white bloom in spring, followed in the fall by clusters of edible fruit, pink at first, then turning black.
$\begin{array}{rlr}18 & \text { to } 24 \\ 2 & \text { to } 3\end{array}$
in.
4.00
35.00
3 to 4
ft.
5.50
50.00
7.50
70.00

V. sieboldi (Siebold Viburnum). 8 to $10 \mathrm{ft}$. Tree-

like, few stemmed shrub with handsome dark green lustrous foliage, creamy flowers, and berries that start out green changing to pink and black.
$\begin{array}{llll}2 & \text { to } & 3 & \mathrm{ft} \\ 3 & \text { to } & 4 & \mathrm{ft}\end{array}$
$3.50 \quad 30.00$
$4.50 \quad 40.00$

V. tomentosum (Doublefile Viburnum). 8 to $10 \mathrm{ft}$. Flat clusters of white flowers are produced along horizontal branches with distinctive purple foliage.
$\begin{array}{llll}2 & \text { to } 3 & \mathrm{ft} . \\ 3 & \text { to } & 4 & \mathrm{ft} .\end{array}$
$3.00 \quad 25.00$
3 to 4 ft. ...................................... $4.00 \quad 35.00$

V. tomentosum plicatum (Japanese Snowball). 7 to 8 ft. Showy white snowballs of June bloom.
18 to 24 in. 
HARDY SHRUBS-Concluded $10 \quad 100$

VITEX agnus castus (Lilac Chastetree). 4 to $5 \mathrm{ft}$. Lilac flowers in late summer from star shaped foliage.
2 to 3
.\$2.50
3 to 4
$\mathrm{ft}$.
3.50

V. macrophylla (Largeleaf Chastetree). 5 to 6 fit. Branching spikes of attractive lavender-blue flowers in late summer stand out well against the star shaped grayish green leaves.

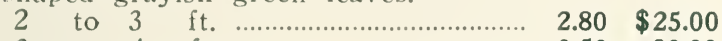

3 to $4 \mathrm{ft}$. ............................... $3.50 \quad 30.00$

WEIGELA amabilis (Rose Weigela). 7 to $8 \mathrm{ft}$. 'The tubular flowers are rosy pink without and paler within, produced in profusion in late spring.

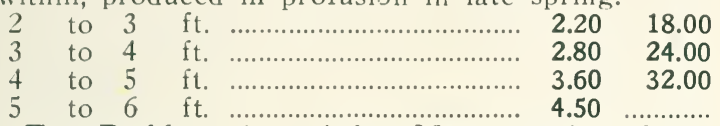

W. Eva Rathke. 4 to $5 \mathrm{ft}$. Most popular of the family, with a superabundance of rich carmine flowers all summer long.

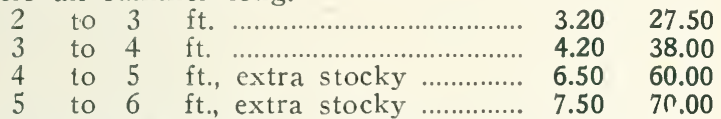

W. floribunda (Crimson Weigela). 7 to $8 \mathrm{ft}$. Many crimson flowers in June. A strong vigorous-growing sort.
2 to 3
3 to 4
4 to 5
ft.
$2.80 \quad 24.00$

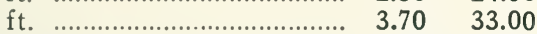

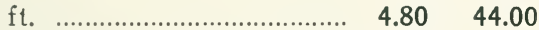

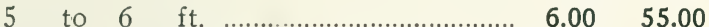

W. nana variegata (Variegated Leaf Weigela). 4 to $5 \mathrm{ft}$. Light pink flowers from variegated foliage on a compact plant.
2 to 3
ft.
3.00

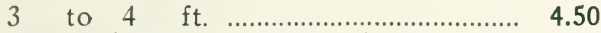

W. rosea (Pink Weigela). 7 to $8 \mathrm{ft}$. Very popular with masses of showy pink bloom in June. A vigorous sort.
2 to $3 \mathrm{ft}$
$2.40 \quad 20.00$
3 to 4
ft.
$3.00 \quad 26.00$
4 to 5
6 to 6

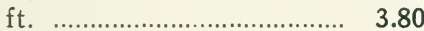
ft. 4.50
34.00
$4.50 \quad 40.00$

W. rosea foliis purpurea (Purpleleaf Weigela). 5 to 6 ft. Bright pink flowers in June and rich bronzepurple foliage.

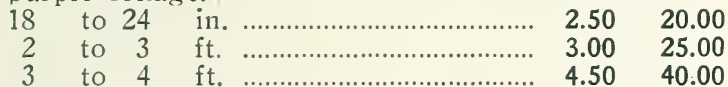

W. steltzneri (Steltzner Weigela). 6 to $7 \mathrm{ft}$. Pink flowers in late spring. One of the best.
18 to 24
in. ............................... 1.60
$1.60 \quad 14.00$

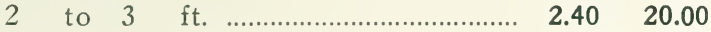

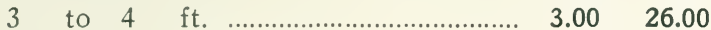

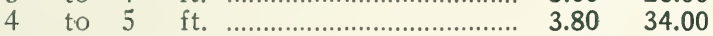

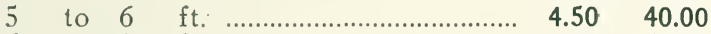

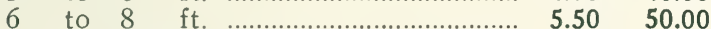

W. van houttei (Van houtte Weigela). 6 to $7 \mathrm{ft}$. Splendid strong-growing variety, flowers dark pink.

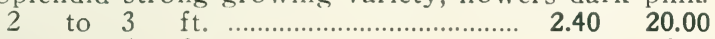

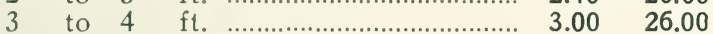

YUCCA filamentosa (Spanish-bayonet, Adams Nee* dle). 2 to $3 \mathrm{ft}$. Evergreen, with long leaves and tall floral spikes in early summer.

4 yr., large clumps ........................... $3.00 \quad 25.00$

Y. filamentosa variegata (Variegated Yucca). Evergreen, with lily-like creamy white flowers in June, and leaves broadly margined yellow.

4 yr., large clumps 


\section{HARDY VINES}

The demand for well grown hardy Vines continues to be exceptionally brisk. However, we have a fairly large supply of dependable, stocky plants, such as cannot fail to please those who recognize high quality slock.

10100

AKEBIA quinata (Fiveleaf Akebia). 15 to $20 \mathrm{ft}$. Dainty, beautiful vine with purple flowers in May and deep green leaves persisting until winter. 2 yrs. old 3 yrs. old $\$ 2.50 \$ 20.00$

AMPELOPSIS Lowi (Geranium Creeper). 6 to $8 \mathrm{ft}$. Clings closely and has beautiful fall coloring. The thick-looking leaves are twisted.

From 2 in. pots ................................. $3.00 \quad 25.00$

A. quinquefolia (Virginia Creeper). 40 to $50 \mathrm{ft}$. Of quick growth, with brilliant crimson fall foliage. The well known and justly popular woodbine.

2 yrs. No. 1 .............................................. $1.80 \quad 15.00$

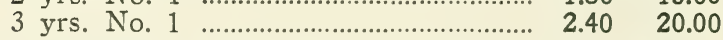

A. quinquefolia engelmanni (Engelmann Creeper). 30 to $35 \mathrm{ft}$. Like the above, but with smaller, though equally beautiful, leaves. Fall foliage is amazingly striking.

3 yrs. No. 1

$2.40 \quad 20.00$

A. tricuspidata (Veitchi) (Boston Ivy, Japanese Creeper). 40 to $50 \mathrm{ft}$. Self clinging and quick growing with lovely scarlet fall foliage. Unfortunately, our supply of these vines is greatly depleted. However, the few that we can still supply are splendid stock.

2 yr. trans., 9 to 12 ir. .................... $1.80 \quad 15.00$

2 yr. trans., 12 to 18 in. ......................... $2.40 \quad 20.00$

BIGNONIA grandiflora (Chinese Trumpet Creeper). 25 to $40 \mathrm{ft}$. A most attractive vine, with large brightly colored trumpet-shaped flowers, which are orange inside, orange-yellow outside.

2 yrs. No. 1

4.50

B. radicans (Trumpetcreeper). 40 to $50 \mathrm{ft}$. Orangescarlet floral trumpets in July.

2 yrs. No. 1

$1.70 \quad 14.00$

CELASTRUS orbiculatus (()rienta! Bittersweet). 15 to $20 \mathrm{ft}$. Bright orange and scarlet fruits on a rapid-growing vine.

2 yrs. No. 1 ......................................... $2.20 \quad 18.00$

3 yrs. No. 1 ........................................... $2.80 \quad 24.00$

C. scandens (American Bittersweet), 20 to $25 \mathrm{ft}$. Fruit of an intense scarlet-orange.

2 yrs. No. 1

$2.20 \quad 18.00$

3 yrs. No. 1

$2.80 \quad 24.00$

CLEMATIS paniculata (Sweet Autumn Clematis). 20 to $30 \mathrm{ft}$. Popular spreading vine with a wealth of flowers like tiny white stars in late summer.

2 yrs. No. 1 


\section{HARDY VINES-Continued}

CLEMATIS-Large-flowered

All varieties, Strong 2 yrs. selected $\$ 4.00$ per 10 , $\$ 35.00$ per 100

CLEMATIS henryi. 10 to $12 \mathrm{ft}$. Large ivory white flowers.

C. jackmani. 10 to $12 \mathrm{ft}$. Most popular of the large-flowered clematis. Bears large, rich violetpurple flowers.

C. Mme. Baron Veillard. 10 to $12 \mathrm{ft}$. A late bloomer and strong grower, with large, satiny pink flowers.

C. Mme. Edouard Andre. 10 to $12 \mathrm{ft}$. Large, rosy carmine flowers.

C. Ramona. 10 to $12 \mathrm{ft}$. Large flowers with lavender-blue petals accentuated by deeper colored anthers.

\section{$\begin{array}{lll}10 & 100 & 1000\end{array}$}

EUONYMUS radicans coloratus (Purple Sharpleaf Wintercreeper). 4 to $5 \mathrm{ft}$. Long, slender, deep green leaves, rosy-purple underneath, and with attractive gray veins.

2 yrs. No. 1

E. rad. variegata (Variegated Wintercreeper). 3 to $4 \mathrm{ft}$. Small, glossy green leaves attractively variegated white.
2 yrs.
$2.00 \quad 16.00$
3 yrs. stocky
$2.80 \quad 24.00$

E rad vectus (Biglea. Wintercreeper) 10 to $12 \mathrm{ft}$ Hardy, evergreen, with showy yellow-podded, red winter fruit.
15 to 18
in.
$5.00 \quad 45.00$
18 to 24
in.
$6.00 \quad 55.00$

HEDERA helix (English Ivy). 40 to $50 \mathrm{ft}$. Evergreen, ideal for a ground cover in the shade, also splendid for a wall covering.

From 2 in. pots.

.90

$7.50 \$ 65.00$

From 3 in. pots, extra fine ..... $1.75 \quad 15.00$

JASMINUM nudiflorum (Winter Jasmine). $4 \mathrm{ft}$. Earliest vine to bloom, with its bright yellow flowers produced in March and early April.
18 to 24
$3.00 \quad 25.00$
2 to 3 ft. ............................. $4.00 \quad 35.00$

LONICERA halliana (Hall Japan Honeysuckle). 20 to $25 \mathrm{ft}$. Popular semi-evergreen vine with exceedingly fragrant buff flowers. One of the best and most popular ground covers, also frequently grown over fences.

2 yrs. No. 1 ............................ $1.50 \quad 12.00 \quad 100.00$

2 yrs. Medium ................................ $1.20 \quad 10.00 \quad 80.00$

L. heckrotti "Goldflame" (Goldflame Honeysuckle). 15 to $20 \mathrm{ft}$. Lovely and fragrant two-toned flowers, bright flame pink without and creamy gold within, are borne in great quantities from early spring to frost.

2 yrs. No. 1

$3.50 \quad 30.00$

L. sempervirens (Scarlet Trumpet Honeysuckle). 15 to $20 \mathrm{ft}$. Showy scarlet flowers from July to October.

2 yrs., Selected .......................... $2.20 \quad 18.00 \quad 150.00$

3 yrs., Heavy ................................ $2.60 \quad 22.00 \quad 180.00$

L. sempervirens magnifica (Everblooming Honeysuckle). 15 to $20 \mathrm{ft}$. Fragrant and beautiful orange-scarlet flowers.
2 yrs. No. 1
$4.00 \quad 30.00$ 
HARDY Vines-Concluded

\section{$10 \quad 100 \quad 1000$}

LYCIUM Barbarum (Barberry Matrimony-vine). 10 to $12 \mathrm{ft}$. Particularly good for seashore planting and perfect for holding banks, with violet June flowers, followed by conspicuous red fruit.
18 to 24
in.
..\$2.00
2 to $3 \mathrm{ft}$.
2.50

POLYGONUM auberti (Silverlace Vine). 25 to 30 ft. Big, foamy sprays of silver-white flowers are produced in unequaled abundance from mid-July until frost.

2 yrs. No. 1

$3.50 \$ 30.00$

3 yrs., extra heavy

$4.50 \quad 40.00$

PUERARIA thunbergi (Kudzu-vine). 35 to $50 \mathrm{ft}$. Big, tropical leaves. Of very rapid growth.

2 yrs. ....................................... $1.50 \quad 12.00$

VINCA minor (Periwinkle). 4 in. Evergreen ground cover, best in shade, with delicate lilac-blue flowers in spring.

From 21 $/ 4$ in. pots ................... $.90 \quad 7.00 \$ 60.00$ $\begin{array}{lllll}\text { From } 3 & \text { in. pots ..................... } & 1.20 & 9.00 & 75.00\end{array}$

V. minor alba. 4 in. White-flowered form of the above.

From 3 in. pots .................... $1.50 \quad 12.00$

WISTERIA sinensis (Chinese Wisteria). 30 to 40 $\mathrm{ft}$. Of exceedingly rapid growth with foot-long racemes of soft lavender-blue flowers in May. Splendid vines, grown from cuttings taken from selected, heavy blooming wood.

2 yrs. No. 1

$4.00 \quad 35.00$

3 yrs. Heavy

$5.50 \quad 50.00$

W. sinensis alba (White Chinese Wisteria). 25 to 30 $\mathrm{ft}$. White flowered form of the above. All grown from cuttings taken from blooming vines.

2 yrs. No. 1

$4.50 \quad 40.00$

3 yrs. Heavy

$6.00 \quad 55.00$

\section{Let Us Quote}

On such large quantities of nursery stock as you have occasion to purchase. We can sometimes quote prices even lower than our attractive printed prices. 
Deciduous Trees-Continued

ACER-Concluded

10100

A. platanoides (Norway Maple). 60 to $70 \mathrm{ft}$. Probably the most popular of all shade trees, with its familiar round head and yellow fall foliage.

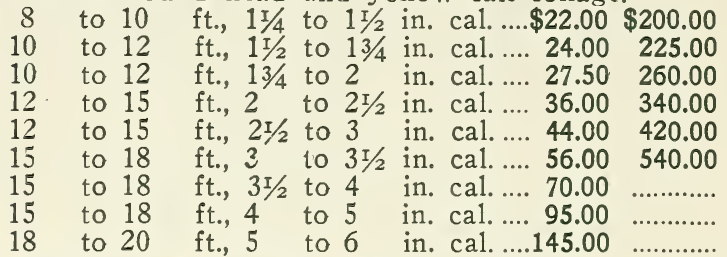

A. platanoides schwedleri (Schwedler Maple). 50 to $60 \mathrm{ft}$. Good lawn specimen with attractive red leaves in spring, turning purplish in the summer.

8 to $10 \mathrm{ft}$., $1 \mathrm{I} / 4$ to $1 \mathrm{I} / 2$ in. cal. ... 30.00280 .00

10 to 12 ft., $11 / 2$ to $13 / 4$ in. cal. ... 35.00330 .00

10 to 12 ft., $13 / 4$ to 2 in. cal.... 40.00380 .00

12 to 15 ft., 2 to $2 \mathrm{r} / 2$ in. cal. ... $50.00 \quad 475.00$

12 to $15 \mathrm{ft}, 2^{\mathrm{I}} / 2$ to 3 in. cal. .... 60.00

15 to $18 \mathrm{ft.}, 3$ to $3 \mathrm{r} / 2$ in. cal. .... 70.00

15 to $18 \mathrm{ft} ., 3 \mathrm{r} / 2$ to 4 in. cal. ... 80.00

A. rubrum (Red Maple). 60 to $80 \mathrm{ft}$. Succeeds in moist or dry soil, and bears attractive red blossoms in spring followed by vivid scarlet foliage in the fall.
8 to $10 \mathrm{ft}$., $1 \mathrm{r} / 4$ to $1 \mathrm{r} / 2$ in. cal. .... 22.50
10 to $12 \mathrm{ft}$., $11 / 2$ to $13 / 4$ in. cal. .... 27.50
10 to $12 \mathrm{ft}$., $13 / 4$ to 2 in. cal. ... 35.00
12 to $15 \mathrm{ft} ., 2$ to $2 \mathrm{r} / 2$ in. cal..... 50.00

A. saccharum (Sugar Maple). 80 to $100 \mathrm{ft}$. Most majestic of the Maples with a brilliant range of autumnal color, from brightest red to orange and yellow.

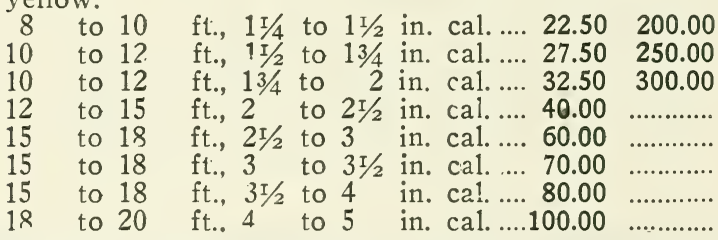

AESCUL'JS hippocastanum (Flowering Horsechestnut). $70 \mathrm{ft}$. Handsome, big white, fragiant flower spikes in June and large, dark green leaves throughout the summer.

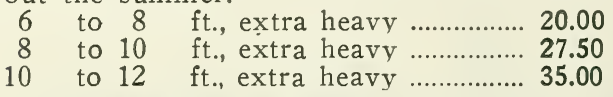

A. hippocastanum rubicunda (Pink Horsechestnut) 40 to $50 \mathrm{ft}$. Great trusses of deep pink flowers beautify this formal roundish pyramid.
$\begin{array}{llll}5 & \text { to } & 6 & \mathrm{ft} . \\ 6 & \text { to } & 8 & \mathrm{ft} .\end{array}$
35.00
45.00

BETULA alba (White Birch). 40 to $50 \mathrm{ft}$. Valuable because of its distinctive and beautiful white bark.

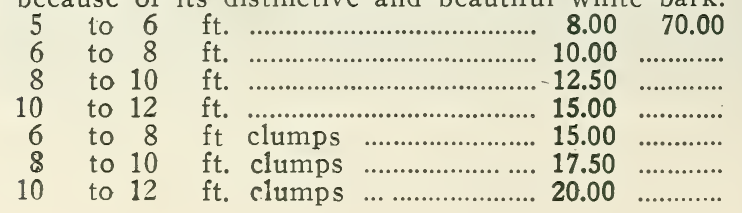


Decinuous Trees-Continued

CORNUS-Concluded

$10 \quad 100$

C. florida rubra (Pinkflowering Dogwood). 25 to 30 $\mathrm{ft}$. Like the foregoing but with deep pink bloom -a gorgeous sight in spring, and again in autumn when it carries most brilliant foliage and great quantities of shiny red berries.

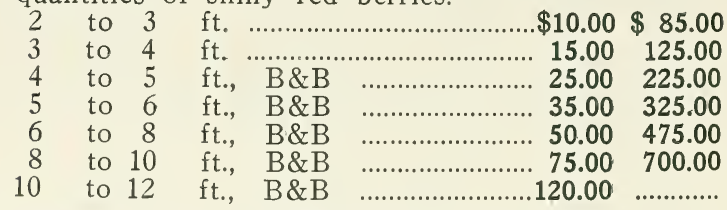

\section{Cornus Florida Rubra}

Extra heavy bushy trees, branched from near the ground.

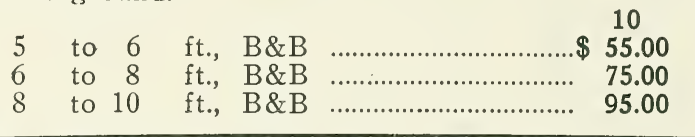

C. kousa (Kousa Dogwood). 16 to $18 \mathrm{ft}$. White flowers in June. Bears conspicuous, cherry-like scarlet fruits, attractive to birds.

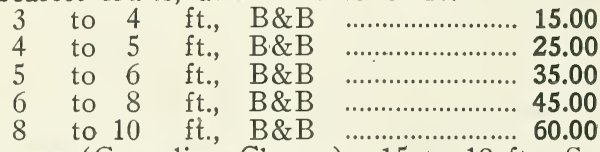

C. mas (Cornelian Cherry). 15 to $18 \mathrm{ft}$. Small yellow flowers in spring, and bright scarlet fruit in the fall.
2 to 3
3 to 4
ft.
5.00
ft.
7.50
4 to $5 \mathrm{ft}$
10.00

CRATAEGUS carrierei (Carriere Hawthorn). 15 to $20 \mathrm{ft}$. Distinctive gray bark, large round orangered fruits persist nearly all winter.

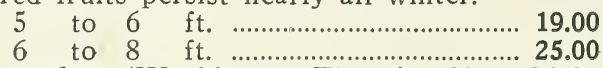

C. cordata (Washington Thorn). 20 to $25 \mathrm{ft}$. White May flowers are followed by bright, lasting scarlet fruits and brilliant autumn foliage.

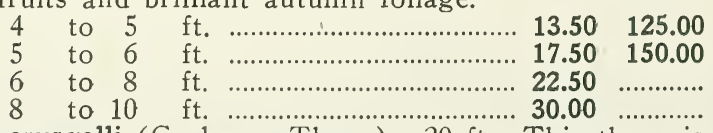

C. crusgalli (Cockspur Thorn). $20 \mathrm{ft}$. This thorn is valuable for the rich shiny green leaves that stay fresh until late autumn, then turn orange. Bears a mass of white flowers, followed by a goodly amount of fruit.

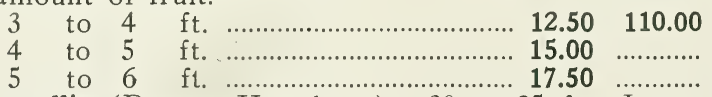

C. mollis (Downy Hawthorn). 20 to $25 \mathrm{ft}$. Large light green thin leaves, showy white red-centered flowers, scarlet succulent fruits, frequently used for jelly.

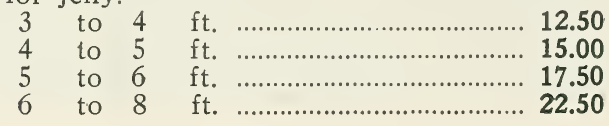


Decinuous Trees-Continucd

10100

C. oxyacantha (English Hawthorn). 20 to $25 \mathrm{ft}$. This "May-Tree" is often used for hedging, but the clusters of large fragrant white flowers, with their elusive fragrance, and red berries, make it worthy of wide use. A great favorite with birds for nesting and food.

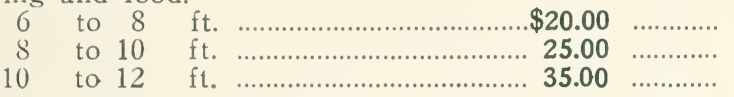

C. oxyacantha. Double Pink Hawthorn. 15 to $20 \mathrm{ft}$. The daintily beautiful pinkflowered Hawthorn.

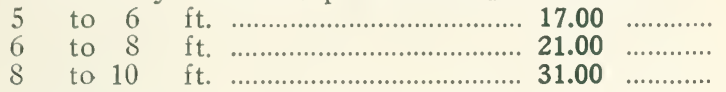

C. oxyacantha, Double White Hawthorn. 12 to $15 \mathrm{ft}$. Double white flowering form of the above.
6 to 8
ft.
21.00
8 to 10
$\mathrm{ft}$.
31.00

C. oxyacantha pauli (Paul's Scarlet Hawthorn). 12 to $15 \mathrm{ft}$. Most popular of the Hawthorns, with a mass of vivid scarlet June flowers and colorful red fruit in winter.

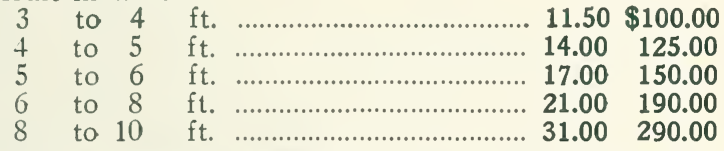

FAGUS sylvatica asplenifolia (Fernleaf Beech). 60 to $70 \mathrm{ft}$. Well named for the deeply cut long narrow graceful leaves.
6 to 8 ft., extra heavy, B\&B ... 85.00
8 to $10 \mathrm{ft}$, extra heavy, B\&B ....120.00

F. syl. purpurea riversi (Rivers Purple Beech). 60 to $70 \mathrm{ft}$. Compact lawn specimens with deep purple foliage.
4 to 5 ft., $\mathrm{B} \& \mathrm{~B}$
5 to 6 ft., B\&B
6 to 8 ft., $B \& B$
8 to 10 ft., $B \& B$
10 to $12 \mathrm{ft}$, $B \& B$
12 to 15 ft., $B \& B$
15 to $18 \mathrm{ft}$, $\mathrm{B} \& \mathrm{~B}$

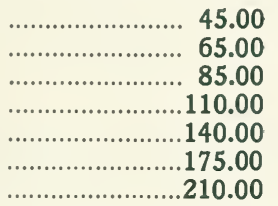
45.00
65.00
85.00
140.00
210.00

FRAXINUS americana (White Ash). 75 to $80 \mathrm{ft}$. A rapid growing shade tree with attractive golden fall foliage. Best in moist location.

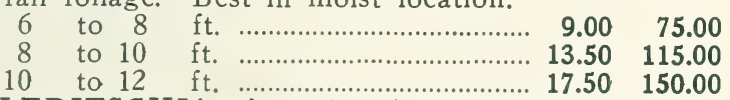

GLEDITSCHIA triacanthos (Honeylocust). 60 to 70 ft. Fragrant white flowers in late spring. Especially good in gravelly soil. Carries long thorns.

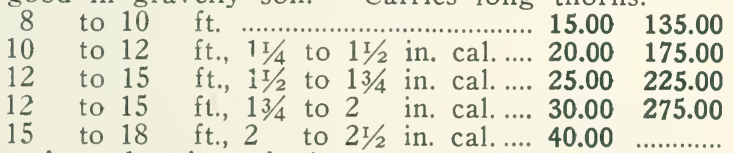

G. triacanthos inermis (Thornless Honeylocust). 60 to $70 \mathrm{ft}$. Similar to the above variety, but without thorns.

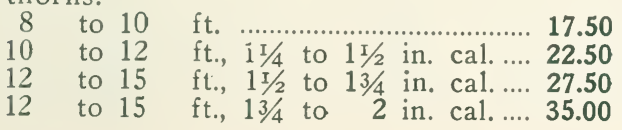


GINKGO biloba (Maidenhair-tree). $100 \mathrm{ft}$. Distinctive fan-shaped leaves on this prehistoric Chinese tree, easily transplanted and good in cities as well as in the country.

\begin{tabular}{|c|c|}
\hline 10 & $11 / 4$ to $1 / 2$ in cal 25 \\
\hline 12 & to $13 / 4$ in. cal..... 35 . \\
\hline 12 & 2 in. cal..... \\
\hline & ft., 2 to $21 / 2$ in. cal. ... 67 . \\
\hline & $\begin{array}{l}\text { ft., } 21 / 2 \text { to } 3 \text { in. cal. ... } 90.00 \\
\text { ft. } 3 \text { to } 31 / 2 \text { in. cal }\end{array}$ \\
\hline
\end{tabular}

KOELREUTERIA paniculata (Varnish tree). 25 to $30 \mathrm{ft}$. Excellent for dry, city conditions. In mid-summer, it carries bunches of bright yellow flowers over attractive compound lateral foliage.

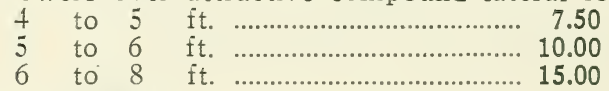

LABURNUM vossi (Voss Goldenchain). $25 \mathrm{ft}$. An improved variety, with very long clusters of yellow flowers.

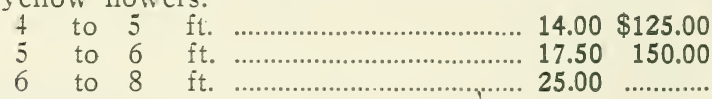

LARIX leptolepis (Japanese Larch). $45 \mathrm{ft}$. Wins admiration as a forerunner of spring foliage. It is tall, graceful, resembling the Spruce or Fir treefor it belongs to the coniferous group, although it drops its leaves, or needles, in winter. Excellent for poolside plantings and swampy places.
3 to 4 ft., $B \& B$

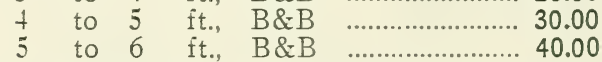

LIQUIDAMBER styraciflua (Sweetgum). 50 to 60 ft. One of the best trees for autumn color; grows well in moist places, and is of upright pyramidal growth.

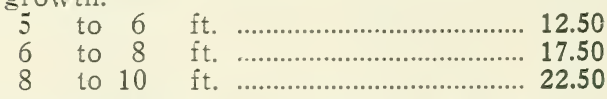

LIRIODENDRON tulipifera (Tuliptree). 80 to 120 ft. A quick grower, with yellow tulip-like flowers in June. Of sturdy growth with clean, straight trunk.
6 to 8
ft.
12.50
8 to $10 \mathrm{ft}$.
15.00

MAGNOLIA glauca (Sweetbay). 15 to $18 \mathrm{ft}$. Deliciously fragrant, large white flowers in May from semi-evergreen, glaucous leaves.

\begin{tabular}{|c|c|c|c|c|c|c|}
\hline to & 2 & & & & & \\
\hline to & 3 & tt., & B\&B & 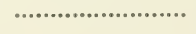 & 12.50 & 15000 \\
\hline & & & $\begin{array}{ll}B \\
B<B\end{array}$ & …………........... & 17.50 & 130.00 \\
\hline & & fi & $B \&$ & 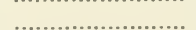 & 32.50 & 300.00 \\
\hline to & & $\mathrm{ft}$. & B\& & & 45.00 & \\
\hline
\end{tabular}

M. halleana stellata (Star Magnolia). 10 to $12 \mathrm{ft}$. Of spreading, shrubty habit, with fragrant, semidouble white flowers appearing long before the leaves.

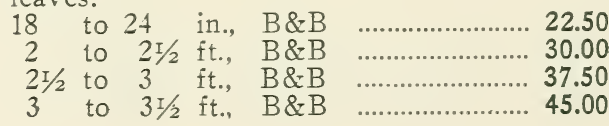


DeCIDUOUS TREes-Continued

$10 \quad 100$

M. halleana stellata rosea (Pink Star Magnolia). 10 to $12 \mathrm{ft}$. One of the most attractive of the Magnolias; color of flowers very attractive, fairly light but bright pink.
18 to $2 t$
in., $B \& B$
$\$ 27.50$
2 to $21 / 2 \mathrm{ft}$., $B \& B$
35.00

M. kobus (Kobus Magnolia). 30 to $40 \mathrm{ft}$. A synlmetrical tree with beautiful semi-double white flowers blooming before the leaves.

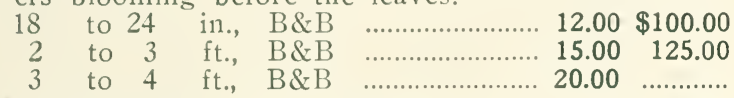

M. soulangeana (Saucer Magnolia). 15 to $18 \mathrm{ft}$. Most popular, by far, of all the Magnolias, with its big purplish pink and white flowers in May.

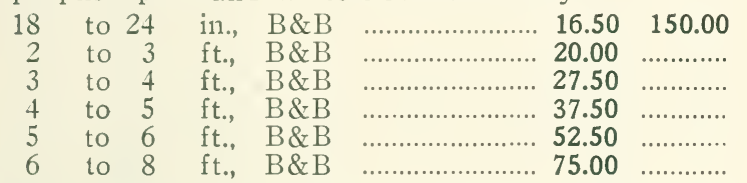

M. soulangeana alexandrina (Alexander Magnolia). 18 to $20 \mathrm{ft}$. Quite similar in general appearance to the Saucer Magnolia, but the flowers appear a little earlier and are of a rosy color.
18 to 24 in., $B \& B$
2 to 3 ft., $\mathrm{B} \& \mathrm{~B}$
20.00
25.00
3 to 4 ft., $\quad$ \& \& B ….................. 30.00

M. soulangeana lennei (Lenne Magnolia). 15 to 18 ft. Rich, very large, deep purple flowers in April.
18 to 24 in., B\&B
2 to $3 \mathrm{ft}$., $\mathrm{B} \& \mathrm{~B}$
3 to 4 ft., $B \& B$
4 to 5 ft., $\quad B \& B$
5 to 6 ft, B\&B …….......... 45.00

M. soulangeana nigra (Purple Lily Magnolia). 15 to $18 \mathrm{ft}$. A mass of deep brownish purple flowers open continuously until early June on this rapid growing tree.
18 to 24 in., $B \& B$
2 to 3 ft., $B \& B$
3 to 4 ft., $\mathrm{B} \& \mathrm{~B}$
4 to 5 ft., $B \& B$
5 to 6 ft., $B \& B$
6 to $8 \mathrm{ft}$., $\mathrm{B} \& \mathrm{~B}$
$19.00 \quad 165.00$
$22.50 \quad 200.00$
$30.00 \quad 275.00$
45.00
60.00
75.00

MALUS atrosanguinea (Carmine $\mathrm{Crab}$ ). 12 to $15 \mathrm{ft}$. Many single dark pink and purplish crimson blooms in late spring.
4 to 5
5 to 6
6 to 8
ft.
8.00
10.00
15.00

M. baccata (Siberian (rab). 15 to $20 \mathrm{ft}$. Round headed, with big white flowers in late spring, followed by red and yellow fruit.
5 to $6 \mathrm{ft}$.
10.00
6 to 8
$\mathrm{ft}$.
15.00
8 to 10
$\mathrm{ft}$.
20.00
10 to $12 \mathrm{ft}$
30.00

M. coronaria (Wild Sweet Crab). 15 to $20 \mathrm{ft}$. Blusli pink flowers in April; double and highly fragrant.
4 to $5 \mathrm{ft}$.
7.50
to 6
10.00
$\mathrm{ft}$.
90.00
6 to 8
8 to 10
$\mathrm{ft}$.
13.50
120.00 
Deciduous Trees-Continued

10100

M. scheideckeri (Scheidecker Crab). 12 to $15 \mathrm{ft}$. Striking clusters of semi-double pink bloom followed by yellow fruits over a half inch in diameter.

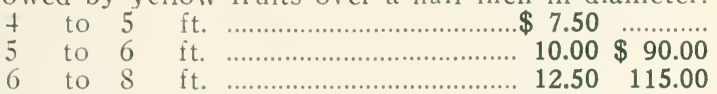

8 to 10 ft. ............................... 17.50

MORUS alba pendula (Teas Weeping Mulberry). 8 to $10 \mathrm{ft}$. Most popular small weeping tree for the lawn.

$3 \mathrm{yr}$. heads, 5 to $6 \mathrm{ft}$. specimens .... 25.00

OXYDENDRUM arboreum (Sourwood). 30 to 35 $\mathrm{ft}$. Handsome tree with vivid scarlet fall foliage and long racenes of white summer flowers, followed by conspicuous gray fruits.

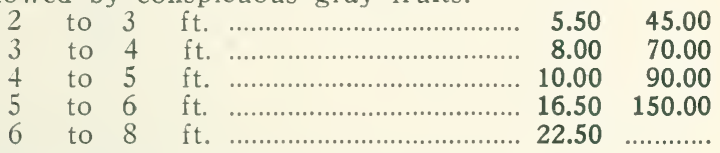

PLATANUS occidentalis (American Plane Tree). $100 \mathrm{ft}$. Seems to prefer a river bank or moist place, where the towering white trunk with its ragged gaunt branches typify independence.

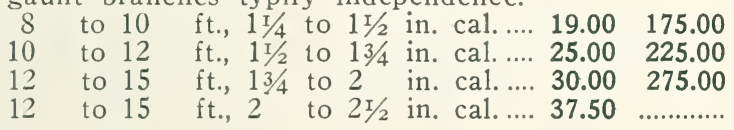

P. orientalis (Oriental Plane). 70 to $80 \mathrm{ft}$. Rapid growing, this tall shade tree is immensely popular for street and seashore planting.

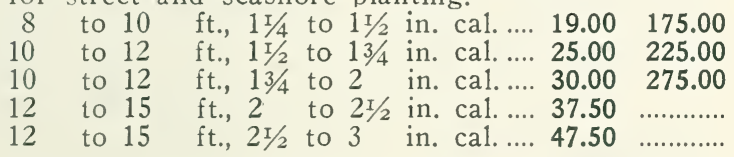

POPULUS bolleana (Bolleana Poplar). 50 to $60 \mathrm{ft}$. Leaves white underneath; of similar columnar character to Lombardy Poplar.
10 to 12
12 to 15
ft. . .................................. 12.00
15 to 18
ft.
17.50
25.00

P. eugenei (Carolina Poplar). 75 to $90 \mathrm{ft}$. Good native shade tree, succeeding in dry spots. Of very rapid growth.

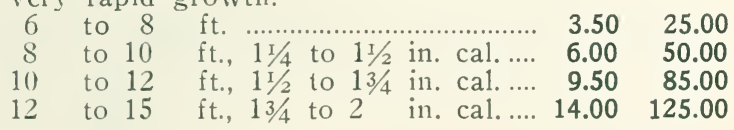

P. nigra italica (Lombardy Poplar). $75 \mathrm{ft}$. Quickly becomes a tall, narrow spire of light green leaves. Most useful for screening or for tall accent trees.

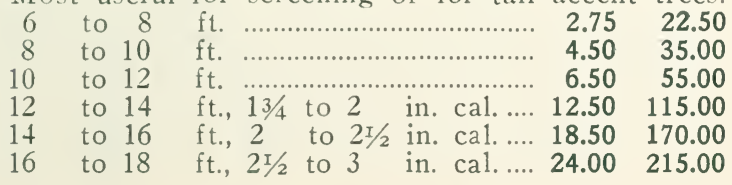


Deciduous Trees-Continued

10100

PRUNUS bleriana (Pink Flowered Plum). 12 to 15 ft. Fragrant double pink flowers stand out well against the purple leaves in early spring.

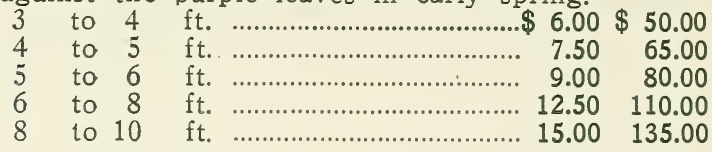

P. Kwanzan. 30 to $40 \mathrm{ft}$. Pink, very double flowers like Roses, in May. Among the very best of the upright growing Flowering Cherries.

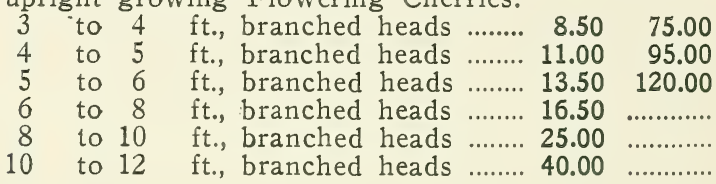

P. Mt. Fuji. $30 \mathrm{ft}$. Best double white-flowering Cherry.

$\begin{array}{rrrrrrr}3 & \text { to } & 4 & \text { ft., branched heads } & \ldots . . . . & 8.50 & 75.00 \\ 4 & \text { to } & 5 & \text { ft., branched heads } & \ldots . . . . & 11.00 & 95.00 \\ 5 & \text { to } & 6 & \text { ft., branched heads } & \ldots . . . . . & 13.50 & 120.00 \\ 6 & \text { to } & 8 & \text { ft., branched heads } & \ldots . . . . . . & 16.50 & 150.00\end{array}$

P. Shirofugen. 25 to $30 \mathrm{ft}$. Pale pink buds open to double white flowers; early.

6 to 8 ft., branched heads ........ 16.50

8 to $10 \mathrm{ft}$., branched heads ........ 25.00

P. subhirtella pendula. 12 to $15 \mathrm{ft}$. Countless single pink blooms almost completely cover the gracefully pendulous branches of this beautiful Weeping Cherry, in early spring.

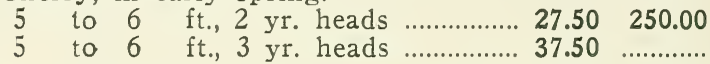

P. subhirtella pendula florepleno. 12 to $15 \mathrm{ft}$. The unbelievably beautiful Doubleflowered Weeping Cherry.
5 to 6 ft., 2 yr. heads
30.00
5 to 6 ft., 3 yr. heads
45.00

P. Thundercloud. 10 to $12 \mathrm{ft}$. A Flowering Plum with very dark reddish purple leaves.
6 to 8
$12.00 \quad 110.00$

8 to 10

$15.00 \quad 135.00$

P. Vesuvius. 10 to $12 \mathrm{ft}$. Another splendid Flowering Plum with deep purple leaves.
3 to 4
$\begin{array}{lll}4 & \text { to } & 5 \\ 5 & \text { to } & 6\end{array}$
$\mathrm{ft}$.
6.50

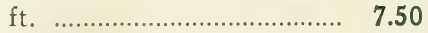
$\mathrm{ft}$.
6 to 8
fi. ..................................... 12.00

P. Yoshino (Yedoensis). 40 to $50 \mathrm{ft}$. The single pink flowers become flushed with purple before falling. An excellent flowering shade tree.
4 to 5 ft., branched heads
11.00
5 to 6 ft., branched heads
13.50
6 to 8 ft., branched heads
16.50 
Decinuous Trees-Continued

QUERCUS alba (White Oak). 60 to $80 \mathrm{ft}$. Slow growing but makes a large, magnificent tree.

8 to 10 ft., $11 / 4$ to $11 / 2$ in. cal. .... $\$ 25.00$

10 to $12 \mathrm{ft} ., 1 \frac{1}{2}$ to $13 / 4$ in. cal.... 30.00

Q. coccinea (Scarlet Oak). 80 to $90 \mathrm{ft}$. Tall and stately, with rich autumnal foliage, deeply cut.
12 to 15
ft., $2 \frac{1}{2}$ to 3
in. cal.... 85.00
15 to $18 \mathrm{ft}$., 3 to $3 \mathrm{r} / 2$ in. cal.....100.00
15 to $18 \mathrm{ft}, 3 \mathrm{I} / 2$ to 4 in. cal.....135.00

15 to $18 \mathrm{ft} ., 4$ to 5 in. cal.....175.00

Q. palustris (Pin Oak). 75 to $90 \mathrm{ft}$. An easily transplanted street tree, long-lived, and carrying a symnetrical head.
10 to $12 \mathrm{ft} ., 11 / 2$ to $13 / 4$ in. cal.... 25.00
10 to $12 \mathrm{ft}, 13 / 4$ to 2 in. cal.... 30.00
10 to $12 \mathrm{ft} ., 2$ to $2 \mathrm{I} / 2$ in. cal.... 40.00
10 to $12 \mathrm{ft}, 2 \mathrm{I} / 2$ to 3 in. cal.... 50.00
12 to $15 \mathrm{ft}, 3$ to 4 in. cal.... 75.00
12 to 15 ft., 4 to 5 in. cal....125.00
15 to $18 \mathrm{ft}, 5$ to 6 in. cal....175.00
18 to $20 \mathrm{ft}$., 6 to 8 in. cal....250.00

Q. robur (English Oak). 60 to $80 \mathrm{ft}$. Long lived oak with stout branches, forming a broad roundtopped head.
8 to 10
10 to 12
ft., $1 \mathrm{I} / 4$ to $1 \mathrm{I} / 2$ in. cal. .... 25.00
10 to 12
ft., $11 / 2$ to $13 / 4$ in. cal..... 30.00
ft., $13 / 4$ to 2 in. cal.... 35.00

Q. rubra (Red Oak). 75 to $85 \mathrm{ft}$. Most rapid growing of Oaks; an ideal shade tree that is best in full sun.
10 to 12
10 to 12
12 to 15
12 to 15
15 to 18
ft., $1 \frac{1}{2}$ to $13 / 4$ in. cal.
$35.00 \$ 325.00$
ft., $13 / 4$ to 2 in. cal. ... 40.00
ft., 2 to $2 \frac{1}{2}$ in. cal.... 50.00
$\mathrm{ft} ., 2 \mathrm{I} / 2$ to 3 in. cal.... 65.00
15 to 18
ft., 3 to 4
in. cal.... 90.00
ft., 4 to 5 in. cal....145.00

SALIX babylonica (Babylon Weeping Willow). 40 to $50 \mathrm{ft}$. Appropriate for waterside planting, with its long, pendulous branches.

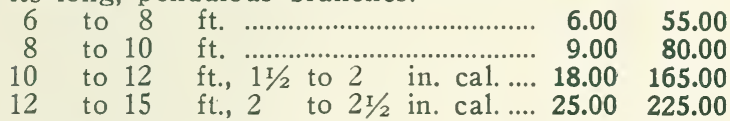

S. pentandra (Laurel Willow). 30 to $40 \mathrm{ft}$. A quick growing tree whose rich shiny green foliage makes it perfect for a background planting.

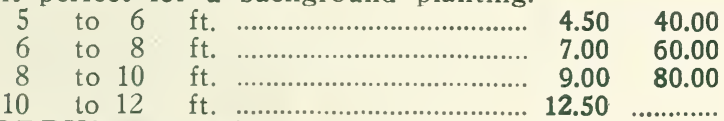

SORBUS aucuparia (European Mountain-ash). 25 to $30 \mathrm{ft}$. Great clusters of orange-scarlet berries make this tree ideal for the small lawn.
5 to 6
6 to 8
ft.
$8.50 \quad 75.00$
8 to 10
10 to 12
$\mathrm{ft}$.
11.00
95.00
14.00125 .00

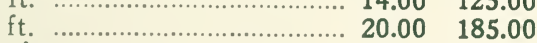

STYRAX japonica (Japanese Snowbell). 18 to 20

ft. In July the wide spreading branches are closely strung with nodding pure white bells. Better as a specimen than when planted in mass.

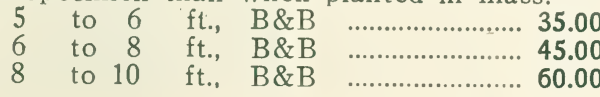




\section{Deciduous TreEs-Concluded}

TILIA americana (American Linden) $\begin{array}{lll}10 & 100\end{array}$ Large limbed round topped tree, handsome in it. dress of great heart shaped leaves.

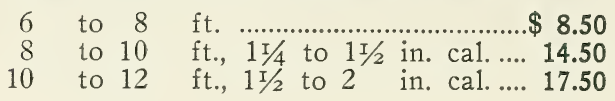

T. cordata (Littleleaf European Linden). 70 to 80 $\mathrm{ft}$. Ideal tree for street or lawn planting, tall growing but low headed, with heart-shaped leaves.

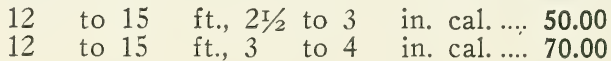

T. platyphyllus (Bigleaf European Linden). $80 \mathrm{ft}$. Very similar habit of growth to that of the American Linden.

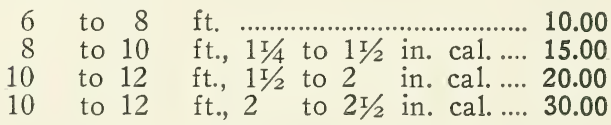

T. platyphyllus pyramidalis (Pyramidal Bigleaf European Linden). 40 to $50 \mathrm{ft}$. Upward growing branches, covered with heart-shaped foliage, render this ideal as an accent tree or to border a narrow drive.

$\begin{array}{rrrr}8 & \text { to } 10 & \mathrm{ft} . \text {, selected specimens .... } & 45.00 \\ 10 & \text { to } 12 & \mathrm{ft.} \text {, selected specimens .... } & 60.00 \\ 12 & \text { to } 15 & \mathrm{ft} . \text {, selected specimens } \ldots . . & 80.00\end{array}$

ULMUS americana (American Elm). 80 to $100 \mathrm{ft}$. Noblest of our native trees and, because of its tendency to carry a tall trunk, a splendid variety to plant near a building where an umbrella effect is desired.

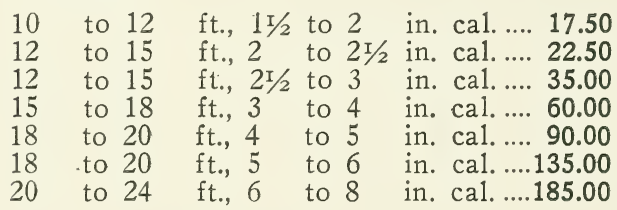

U. americana (Moline Type). 80 to $100 \mathrm{ft}$. Rapidly becomes compact and upright, like a Sugar Maple.
15 to 18
ft., 2 to $2 \mathrm{I} / 2$ in. cal. .... 35.00
15 to 18
ft., $2 \mathrm{~T} / 2$ to 3
in. cal. .... 45.00
20
to 25
$\mathrm{ft}$., 3 to 4
in. cal. .... 70.00
ft., 4 to 5
in. cal. ....100.00

U. pumila (Siberian Elm). 50 to $70 \mathrm{ft}$. Most rapid growing shade tree; graceful, with dense foliage.

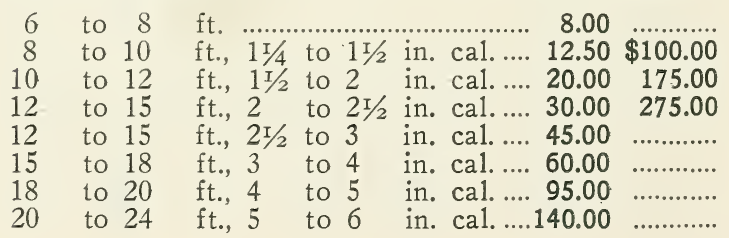




\section{EVERGREEN TREES}

Not only are our Evergreen Trees sheared and transplanted frequently, but also they are given ample space for both root and top development. We do not believe that better specimens can be found anywhere: moreover, we invariably grade our evergreens according to the standards adopted by the American Association of Nurserymen.

All prices of Evergreens, quoted in this trade list refer to extra selected specimens, carefully dug with balls of earth, encased in burlap or similar material.

$10 \quad 100$

ABIES concolor (White Fir). 50 to $70 \mathrm{ft}$. Good specimen trees with lovely blue-gray foliage.

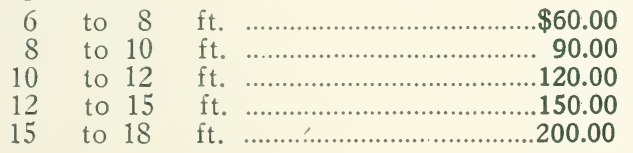

BIOTA or. aurea nana (Berckman's Golden Arborvitae). 4 to $5 \mathrm{ft}$. Compact ovals of golden spring foliage which becomes reddish brown, tipped gold, in winter. Among the most popular of all Evergreens,

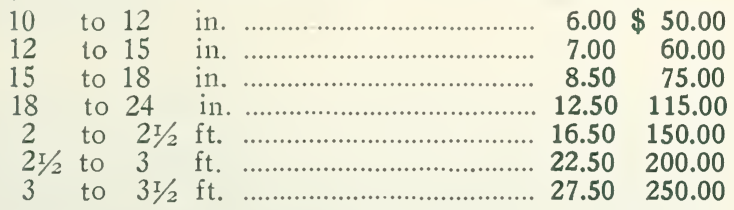

B. or. aurea nana globosa (Berckman's Golden Globe Arborvitae). $2 \mathrm{ft}$. Slow growing, compact globes of golden foliage, valuable for formal gardens and for using in the foreground of Evergreen group plantings.

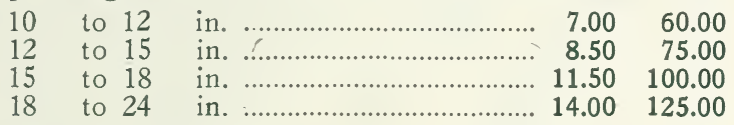

B. or. bakeri (Baker Arborvitae). 6 to $8 \mathrm{ft}$. Compact green columns, lemon yellow in spring. Good for accent plants.

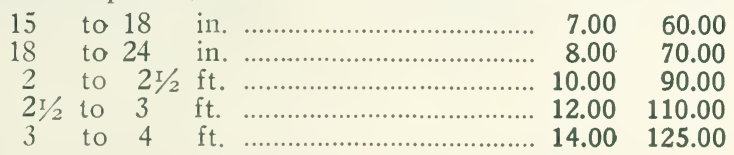

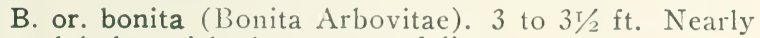
globular, rich deep green foliage.

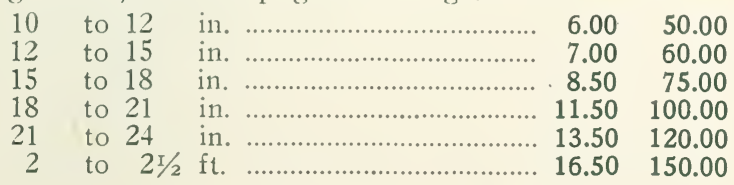




\section{Evergreex Trees-Continued}

\section{BIOTA-Concluded}

10100

A columnar Biota, whose bright yellow foliage turns

18 to 24 in. $\$ 10.00 \$ 90.00$

$\begin{array}{ll}2 & \text { to } 2 \mathrm{I} / 2 \\ 2 \mathrm{I} / 2 & \text { to } 3 \\ 3 & \text { to } 4 \\ 4 & \text { to } 5 \\ 5 & \text { to } 6 \\ 6 & \text { to } 8\end{array}$

$12.50 \quad 115.00$

ft.

$\begin{array}{ll}17.50 & 160.00\end{array}$

$\mathrm{ft}$.

25.00

35.00

ft.

50.00

6 to 8

65.00

B. or. conspicua (Goldspire Arborvitae). 10 to $12 \mathrm{ft}$. to old gold and brown in the winter time.

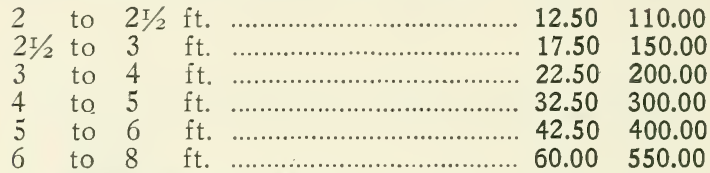

B. or. elegantissima (Yellow Column Arborvitae). 8 to $10 \mathrm{ft}$. Compact columns of green foliage, turning golden bronze in winter.

B. or. excelsa (Excelsa Arborvitae). $20 \mathrm{ft}$. Columnar ovals of vertical, deep green foliage. closely pressed.

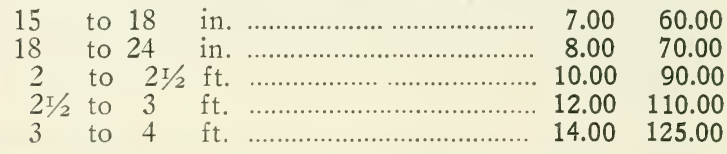

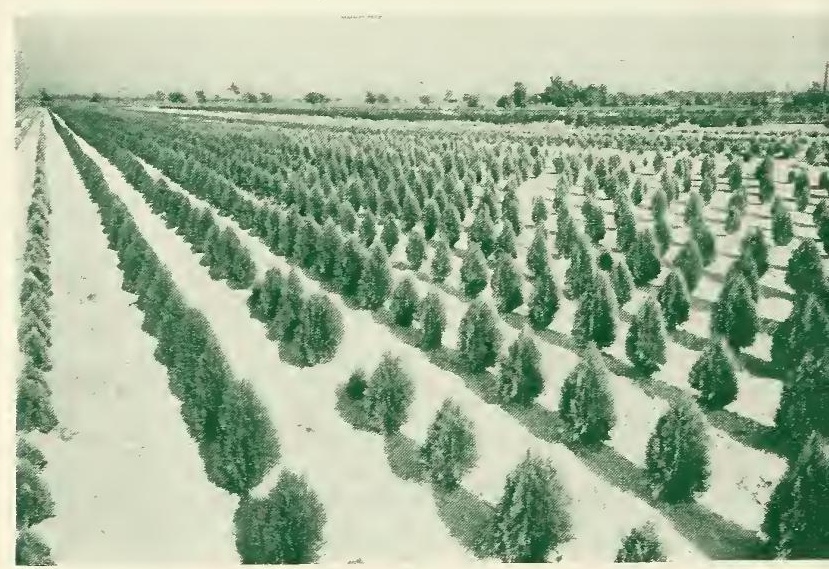

Biota or. Aurea Nana-as we grow them

CEDRUS atlantica glauca (Blue Atlas Cedar). 60 to $70 \mathrm{ft}$. Wide spreading silver-blue pyramids, slow growing. A very beautiful Evergreen.

$\begin{aligned} 6 & \text { to } 8 \\ 8 & \text { to } 10 \\ 10 & \text { to } 12 \\ 12 & \text { to } 15 \\ 15 & \text { to } 18\end{aligned}$

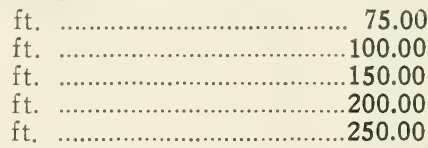

CHAMAECYPARIS (Retinospora). See pages 50-51. 
EVERgReen Trees-Continued

$10 \quad 100$

CRYPTOMERIA lobbi compacta (Cave Cryptomeria). 50 to $60 \mathrm{ft}$. Wide evergreen columns, amazingly rich bronze in winter.

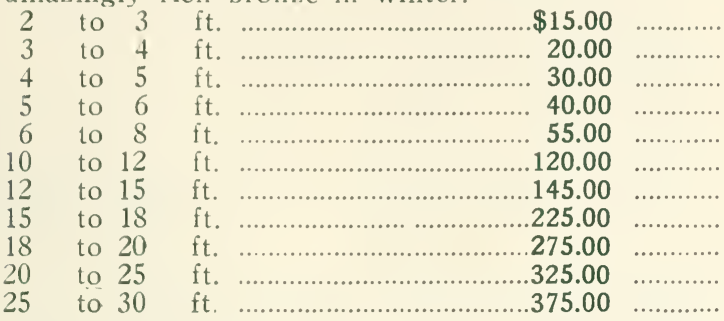

ILEX opaca (American Holly). 30 to $40 \mathrm{ft}$. The familiar Holly which we always associate with Christmas.

\begin{tabular}{|c|c|c|c|c|c|c|}
\hline 18 & to 24 & in., & $B \& B$ & & 10.00 & $\$ 90.00$ \\
\hline 2 & to 3 & ft., & B\&B & & 16.00 & 145.00 \\
\hline 3 & to & ft., & $B \& B$ & & 25.00 & 225.00 \\
\hline 4 & to & ft., & $\mathrm{B} \& \mathrm{~B}$ & 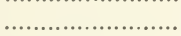 & 35.00 & 325.00 \\
\hline 5 & to & ft., & $B \& B$ & & 45.00 & 425.00 \\
\hline 6 & to & ft., & $B \& B$ & ........................ & 65.00 & \\
\hline
\end{tabular}

JUNIPERUS chinensis alba variegata (White Leaf Chinese Juniper). 8 to $10 \mathrm{ft}$. A stocky pyramid of blue-gray foliage, with creamy white branchlets interningled.

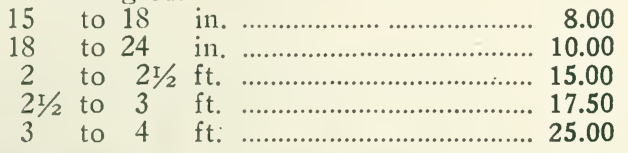

J. chinensis columnaris glauca (Blue Column Chinese Juniper). 20 to $25 \mathrm{ft}$. Tall narrow spires of deep gray-green. One of the best of all pyramidal type Evergreens.

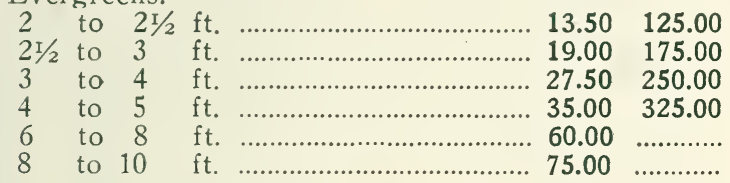

$\mathrm{J}$. chinensis columnaris viridis (Green Column Juniper). 20 to $25 \mathrm{ft}$. Light green form of the above.
2 to $2 \mathrm{r} / 2 \mathrm{ft}$.
$13.50 \quad 125.00$
$2 \mathrm{r} / 2$ to $3 \mathrm{ft}$.
$19.00 \quad 175.00$
3 to $4 \mathrm{ft}$.
27.50

J. chinensis fortunei (Fortune Juniper). 10 to $12 \mathrm{ft}$. Broad pyramids of gray-green foliage.

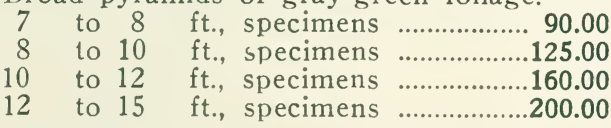

J. chinensis neaboriensis (Conical Chinese Juniper). Possibly the most formal cone-shaped Juniper we have. A perfect accent or tub plant.
2 to $2 \mathrm{r} / 2 \mathrm{ft}$.
15.00
$2 \mathrm{r} / 2$ to $3 \mathrm{ft}$.
20.00
3 to $4 \mathrm{ft}$.
30.00 
Evergreen Trees-Continued

\section{JUNIPERUS-Continued}

$10 \quad 100$

$\mathrm{J}$. chinensis pfitzeriana (Pfitzer Juniper). 5 to $6 \mathrm{ft}$. Best vase-shaped Juniper, adaptable to soil and climate and resistant to city dust and smoke. Feathery, gray-green foliage. Highly popular. Our Pfitzers are unusually compact and dense this year.

$\begin{array}{ll}12 & \text { to } 15 \\ 15 & \text { to } 18 \\ 18 & \text { to } 24 \\ 2 & \text { to } 2 \mathrm{I} / 2 \\ 2 \mathrm{I} / 2 & \text { to } 3 \\ 3 & \text { to } 4 \\ 4 & \text { to } 5\end{array}$

in. spread $\$ 7.00 \$ 60.00$

$10.00 \quad 90.00$

in. spread

$15.00 \quad 135.00$

ft. spread

21.00195 .00

ft., spread

25.00235 .00

ft. spread

ft. spread

$35.00 \quad 325.00$

J. chinensis pfitzeriana compacta (Compact Pfitzer). 4 to $5 \mathrm{ft}$. Compact form of the Pfitzer Juniper. Remains bushy and compact without pruning.
2 to $2 \mathrm{r} / 2 \mathrm{ft}$. spread
$2 \mathrm{r} / 2$ to $3 \mathrm{ft}$. spread
3 to $4 \mathrm{ft}$. spread
25.00
4 to 5 ft. spread
$30.00 \quad 275.00$
$40.00 \quad 375.00$

J. chinensis Sargenti (Sargent Juniper). 8 to 10 in. high. Creeper, forms a bright grass-green mat.
18 to 24
in. spread
20.00

2 to $2 \mathrm{I} / 2 \mathrm{ft}$., spread

27.50

J. communis aurea (Golden Juniper). 1 to $1 \mathrm{I} / 2 \mathrm{ft}$. Low and spreading, with bright golden foliage.
15 to 18 in. spread
18 to 24 in. spread
2 to $2 \mathrm{r} / 2 \mathrm{ft}$. spread
8.50
12.50
18.50
$2 \mathrm{I} / 2$ to $3 \mathrm{ft}$. spread
25.00

J. communis depressa plumosa (Plumed Spreading Juniper). $1 \mathrm{ft}$. Distinctive reddish-purple winter foliage and almost a "creeper."
18 to 24 in. spread
2 to $2 \mathrm{r} / 2 \mathrm{ft}$. spread
$2 \mathrm{r} / 2$ to $3 \mathrm{ft}$. spread
12.50110 .00
3 to $4 \mathrm{ft}$. spread
15.00
20.00
25.00

J. communis hibernica (Irish Juniper). 7 to $8 \mathrm{ft}$. Narrow, dense, stiff columns of blue-green foliage. These are real bargains.
15 to 18
18 to 24
in.
7.00
60.00
2 to $21 / 2 \mathrm{ft}$.
$8.50 \quad 75.00$
$2 \mathrm{~T} / 2$ to $3 \mathrm{ft}$
$11.00 \quad 95.00$
3 to 4 ft
$13.50 \quad 120.00$
4 to 5
$18.50 \quad 165.00$
$25.00 \quad 225.00$

J. communis Kiyonoi (Compact Columnar English Juniper). 8 to $10 \mathrm{ft}$. Similar in appearance to Irish Juniper, but more compact and narrow.
4 to 5 ft.
$20.00 \quad 175.00$
5 to $6 \mathrm{ft}$.
$25.00 \quad 225.00$

$\mathrm{J}$. communis oblongo (Oblong Juniper). 7 to $8 \mathrm{ft}$. A broad, irregular pyramid of feathery, gray-green branches.
8. to 10
10 to 12
$\mathrm{ft}$.
125.00
165.00

$\mathrm{J}$. communis oblongo pendula (Weeping Juniper). 6 to $7 \mathrm{ft}$. An attractive weeping type of the above Juniper.

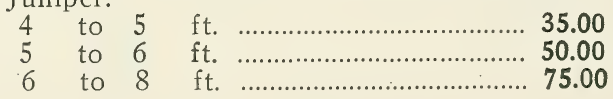


Evergreen Trees-Continued

$10 \quad 100$

J. communis prostrata (Prostrate Juniper). $1 \mathrm{ft}$ With branches spreading along the ground, this Evergreen is well adapted to rockeries, and for the front of evergreen groups.
15 to 18 in. spread
$\$ 11.00 \$ 100.00$
18 to 24 in. spread
2 to $2 \mathrm{I} / 2 \mathrm{ft}$. spread ..................... $17.50 \quad 160.00$
$2 \mathrm{r} / 2$ to $3 \mathrm{ft}$. spread .................. $22.50 \quad 200.00$
3 to $4 \mathrm{ft}$. spread ...................... $30.00 \quad 275.00$

J. communis suecica (Swedish Juniper). 5 to $6 \mathrm{ft}$. Quick growing, narrow, upright pyramids, densely foliaged gray-green.
15 to 18
18 to 24 in
$8.00 \quad 70.00$
$10.00 \quad 90.00$
$2 \mathrm{I} / 2$ to $3 \mathrm{ft}$.
$12.50 \quad 115.00$
3 to $4 \mathrm{ft}$.
$15.00 \quad 135.00$

J. excelsa stricta (Spiny Greek Juniper). 5 to $6 \mathrm{ft}$. Compact, broad pyramids of stiffly erect gray-green foliage. Justly popular variety.

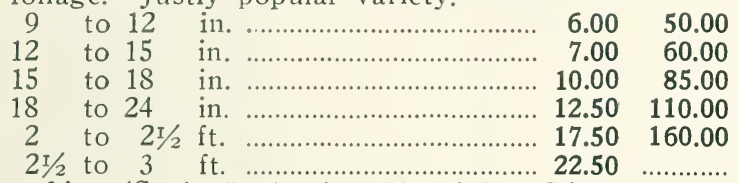

J. sabina (Savin Juniper). 4 to $5 \mathrm{ft}$. Of urn shape with dense deep green foliage.
15 to 18 in. spread
$12.50 \quad 115.00$
18 to 24 in. spread ....................... 15.00 140.00
2 to $2 \mathrm{r} / 2 \mathrm{ft}$. spread ................... 20.00
$2 \mathrm{r} / 2$ to $3 \mathrm{ft}$. spread .................... 25.00
3 to $4 \mathrm{ft}$ spread ................... 32.50

J. sabina tamarisifolia (Tamarix Savin Juniper). $1 \mathrm{I} / 2$ to $2 \mathrm{ft}$. Queer and fascinating in its wide spreading growth and blue-green feathery foliage.
12 to 15
in. spread
9.00
15 to 18
in. spread
12.50
18 to 24
in. spread
17.50
2 to $2 \mathrm{r} / 2 \mathrm{ft}$. spread
22.50

J. squamata Meyeri (Meyer Juniper). 6 to $8 \mathrm{ft}$. Grayblue foliage, with a suggestion of pink toward the ends of the branches in the winter time. A beautiful variety of rather dwarf, grotesque growth.
12 to 15
in.
$8.50 \quad 75.00$
15 to 18
18 to 24
$13.50 \quad 120.00$
in.
$18.50 \quad 170.00$
2 to $2 \mathrm{I} / 2 \mathrm{ft}$.
25.00225 .00

J. virginiana (Redcedar). 35 to $50 \mathrm{ft}$. Our native Evergreen, all nursery grown. Compact in growth, pyramidal in shape, and with bright green foliage, purplish in winter. Useful in formal work, and in mixed plantings.
2 to $3 \mathrm{ft}$.
$13.50 \quad 120.00$
3 to 4
4 to 5
5 to 6
6 to 8

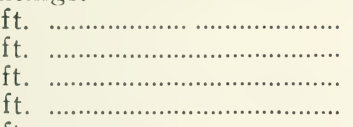
18.00165 .00
$27.50 \quad 250.00$ $37.50 \quad 350.00$

J. virginiana burki (Burk's Juniper). 12 to $15 \mathrm{ft}$. Pright silvery blue during the summer months, and overlaid with purple in winter. Of dense, columnar growth.
2 to $2 \mathrm{r} / 2 \mathrm{ft}$
$16.00 \quad 145.00$
3 to $4 \mathrm{ft}$
$25.00 \quad 225.00$
$30.00 \quad 275.00$ 
Evergreen Trees-Continued

JUNIPERUS-Concluded 10100

J. virginiana cannarti (Cannart Redcedar), 20 to 25 ft. Dense, blackish-green columns with fall berries of steel-blue.

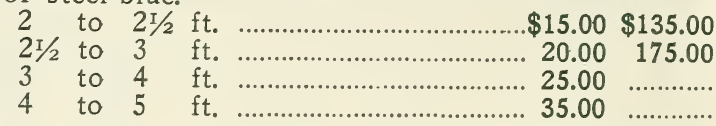

J. virginiana elegantissima (Gold Tip Redcedar). 12 to $15 \mathrm{ft}$. Pyramids, with branches tipped bright yellow in summer and lovely bronze in winter.

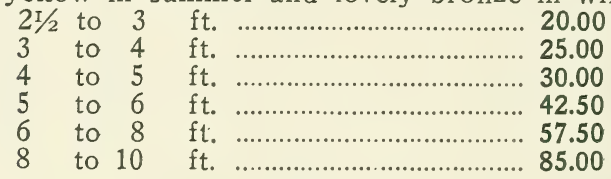

J. virginiana glauca (Silver Redcedar). 20 to $25 \mathrm{ft}$. Tall, narrow columns of blue-gray foliage.

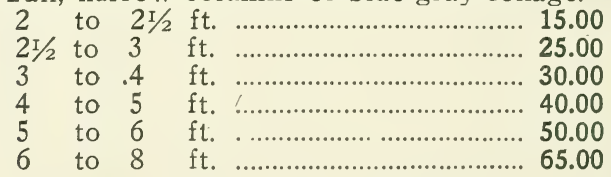

$\mathrm{J}$. virginiana globosa (Globe Redcedar). 4 to $5 \mathrm{ft}$. Needs no trimming to keep it dwarf and compact. Interesting shapes are assumed, as the plants mature.
18 to 24 in.
20.00
2 to $2 \mathrm{r} / 2 \mathrm{ft}$.
25.00
$2 \mathrm{r} / 2$ to $3 \mathrm{ft}$.
30.00

J. virginiana keteleeri (Keteleer Cedar). 18 to $20 \mathrm{ft}$. An upright Evergreen of broad, pyramidal form. Its dense, deep green scale-like foliage contrasts well with the numerous attractive berries it carries.

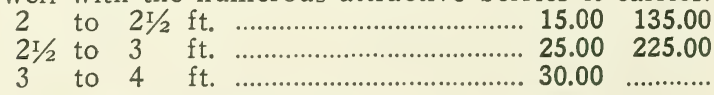

J. virginiana Kosteriana (Koster's Spreading Juniper). $6 \mathrm{ft}$. spread. Growth almost identical with that of the Pfitzer's Juniper except it is bluer in color.
18 to 24 in. spread
2 to $2 \mathrm{r} / 2 \mathrm{ft}$. spread ................... 20.00
$2 \mathrm{r} / 2$ to $3 \mathrm{ft}$. spread ...................... 30.00

J. virginiana pyramidiformis (Dundee Juniper). 15 to $20 \mathrm{ft}$. Compact, symmetrical growth, grayish green foliage, changing to deep purple in winter.

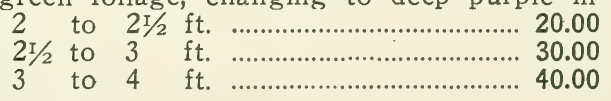

J. virginiana Schotti (Schott Redcedar). 18 to $20 \mathrm{ft}$. Bright green, fine foliage, compact growth.
2 to $2 \mathrm{~T} / 2 \mathrm{ft}$.
$2 \mathrm{~T} / 2$ to 3 ft.
15.00
20.00
25.00

PICEA canadensis (alba) (White Spruce). 50 to $60 \mathrm{ft}$. Slow growing and exceptionally shapely, with dense silvery foliage.

12 to 18 in.

8.50

75.00 


\section{EvergReEn Trees-Continued}

10100

P. excelsa (Norway Spruce), 80 to $90 \mathrm{ft}$. The popular Christmas tree. Of quite rapid growth and very hardy.
15 to 18
18 to 24
in.
$\$ 8.50 \$ 75.00$
2 to 3
$\mathrm{ft}$.
$10.00 \quad 90.00$
$15.00 \quad 135.00$

P. excelsa conica (Arrowhead Norway Spruce). 8 to $10 \mathrm{ft}$. A slow growing, compact, pyramidal, cone-shaped evergreen.
8 to 10
$\mathrm{ft}$.
80.00
10 to 12
$\mathrm{ft}$.
120.00

P. orientalis (Oriental Spruce). 70 to $80 \mathrm{ft}$. Graceful broad pyramids of dark green.
10 to 12
12 to 15
$\mathrm{ft}$.
.150 .00
200.00
to 18
250.00

P. pungens (Colorado Spruce). 70 to $80 \mathrm{ft}$. Symmetrical when young, and even more picturesque in old age, are these broad gray-green pyramids.
3 to $4 \mathrm{ft}$
4 to 5
25.00225 .00
5 to 6
ft.
$35.00 \quad 325.00$
6 to 8
8 to 10
10 to 12
12 to 15
$45.00 \quad 425.00$
ft.
$60.00 \quad 550.00$
ft.
90.00
ft. ………………………….......125.00
ft.
175.00

P. pungens glauca (Blue Colorado Spruce). 70 to 80 ft. A true lawn specimen with horizontal branches, which are covered with attractive thick needles of rich, steel-blue.
$\begin{aligned} 3 & \text { to } 4 \\ 4 & \text { to } 5 \\ 5 & \text { to } 6 \\ 6 & \text { to } 8 \\ 8 & \text { to } 10 \\ 10 & \text { to } 12 \\ 12 & \text { to } 15\end{aligned}$
$\mathrm{ft}$.
$47.50 \quad 450.00$
$57.50 \quad 550.00$
ft. ………………….............. 70.00

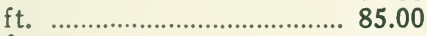
ft. ……………………….......120.00
ft. .........................................150.00
$\mathrm{ft}$.
200.00

P. pungens kosteri (Koster Blue Spruce), 50 to $60 \mathrm{ft}$. Bluest of all blue Spruces.
4 to 5
5 to 6
6 to 8
8 to 10
$10 \quad \mathrm{t} \prime \prime 12$
$\mathrm{ft}$.
$\mathrm{ft}$.
$\mathrm{ft}$.
$\mathrm{ft}$.
95.00
.115 .00
150.001350 .00
200.001850 .00

PINUS montana mughus (Mugho Pine). 3 to $4 \mathrm{ft}$. The popular, round-topped dwarf evergreen. Attractive at all times, but particularly so in spring when its new growth has the appearance of small, erect candles.
10 to 12
12 to 15
in. spread
$9.50 \quad 85.00$
15 to 18
in. spread
$\begin{array}{rr}11.50 & 100.00\end{array}$
18 to 24
in. spread
$16.50 \quad 145.00$
in. spread
$22.50 \quad 200.00$

P. nigra (austriaca) (Austrian Pine). 50 to $60 \mathrm{ft}$. Stiff, deep green needles on upward curving boughs. Very hardy and even thrives near the seashore.
2 to 3
$\mathrm{ft}$.
$19.00 \quad 175.00$
3 to 4
$\mathrm{ft}$.
$30.00 \quad 275.00$
40.00 


\section{Evergreen Trees-Contimued}

\section{PINUS-Concluded}

$10 \quad 100$

P. resinosa (Red Pine). $75 \mathrm{ft}$. Glossy green needles contrast with the reddish brown bark. Thrives even when planted in pure sandy soil.

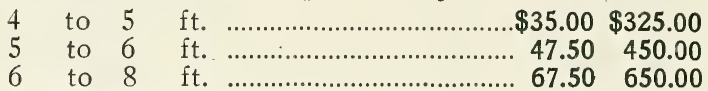

P. sylvestris (Scotch Pine). 60 to $70 \mathrm{ft}$. Blue-green, twisted needles. Hardy, and of rapid, vigorous growth.

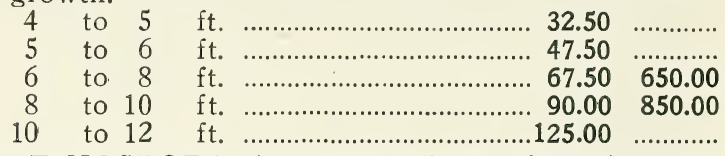

RETINOSPORA (cupressus) Lawsoniana (Lawson Cypress). 80 to $90 \mathrm{ft}$. Glaucous green foliage in vertical rows.

\begin{tabular}{|c|c|c|c|}
\hline & to 24 & in. & 100 \\
\hline & to $2 \frac{1}{2}$ & ft. . ... & 13.50 \\
\hline $21 / 2$ & to & ft. & 17.50 \\
\hline & to & 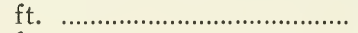 & 25.00 \\
\hline & to 5 & . & 35.00 \\
\hline & to 6 & ft. & 45.0 \\
\hline
\end{tabular}

R. obtusa compacta (Football Cypress). 3 to $5 \mathrm{ft}$. Dwarf and compact, with rich green foliage.

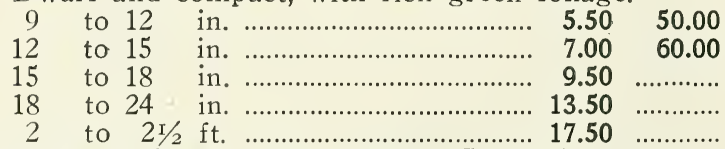

R. obtusa crippsi (Cripps Golden Cypress). 10 to 12 ft. Lemon-yellow foliage on a slow-growing, bushy tree.
15 to 18
12.50
18 to 24
in.
17.50
2 to $21 / 2 \mathrm{ft}$
25.00

R. pisifera (Sawara Cypress). 40 to $50 \mathrm{ft}$. Loose, broad pyramid of lacy green.
18 to 24
10.00
90.00
2 to $2 \mathrm{I} / 2 \mathrm{ft}$
$14.00 \quad 125.00$
$2 \mathrm{r} / 2$ to $3 \mathrm{ft}$.
$17.00 \quad 150.00$
3 to 4
$22.50 \quad 210.00$
5 to 6
6 to 8
45.00
$\mathrm{ft}$.
65.00
8 to 10
85.00

R. pisifera aurea (Golden Sawara Cypress). 35 to $40 \mathrm{ft}$. Goldenleaved form of above, especially bright in spring.

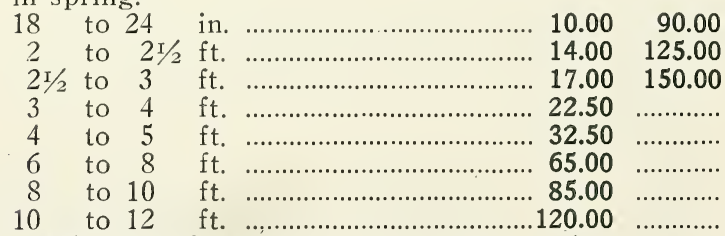

R. pisifera filifera (Thread Cypress). 15 to $20 \mathrm{ft}$. Green foliage droops on threadlike branches.
15 to 18
18 to 24
2 to $2 \mathrm{I} / 2 \mathrm{ft}$
9.00
$2 \mathrm{r} / 2$ to 3
3 to 4
12.50
in.
17.50
22.50
30.00
4 to 5
45.00 
EVERGREEN TREES-Continued

10100

R. pisifera filifera aurea (Goldenthread Cypress). 10 to $12 \mathrm{ft}$. Ideal specimen evergreen, slower in growth than above. Brilliant gold foliage.

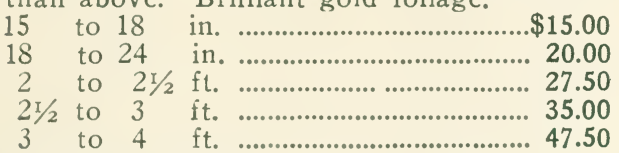

R. pisifera plumosa (Plume Cypress). 35 to $40 \mathrm{ft}$. Soft feathery pyramids of fernlike foliage; good for a hedge, also for use as an individual specimen. 15 to 18 in. ...................................... $8.00 \$ 70.00$ 18 to 24 in. ........................................... $10.00 \quad 90.00$

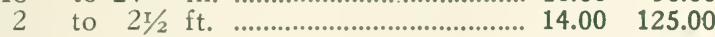

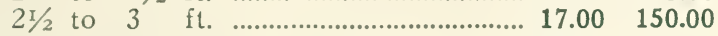
3 to 4 ft. .......................................... 22.50 ............ 6 to 8 ft. ............................................... 65.00

8 to 10 ft. ....................................... 85.00

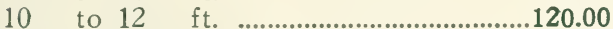

R. pisifera plumosa aurea (Golden-plume Cypress). 20 to $30 \mathrm{ft}$. Warm golden plumes, easily trimmed. One of the most popular of all golden Evergreens.

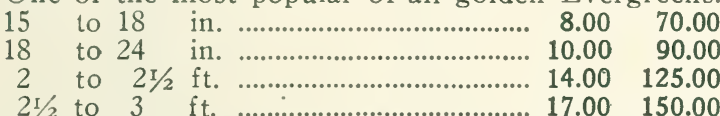

R. pisifera plumosa aurea lovetti (Gold Dust Cypress). 20 to $25 \mathrm{ft}$. Best of all Evergreens for a lawn specimen, with apparently a sheen of purest gold dust overlying its graceful plumes of foliage. Also very desirable for mixed plantings.

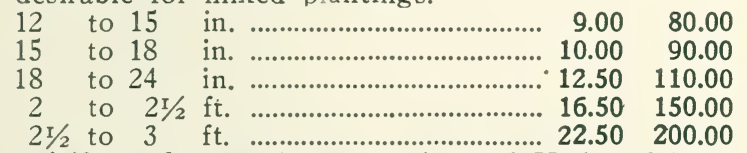

R. pisifera plumosa lutescens (Dwarf Yellow Plume Cypress). $3 \mathrm{ft}$. Round-topped bush, low and broad, with bright sulphur-tipped branches.

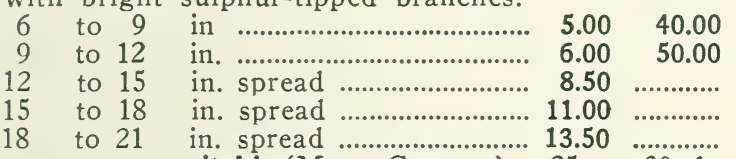

R. squarrosa veitchi (Moss Cypress). 25 to $30 \mathrm{ft}$. Distinctly different, with soft blue-green foliage, dense and feathery. Broadly pyramidal.
15 to 18
18 to 24
in.
$8.00 \quad 70.00$
2 to $2 \mathrm{r} / 2 \mathrm{ft}$
$10.00 \quad 90.00$
in.
$14.00 \quad 125.00$
$2 \mathrm{r} / 2$ to $3 \mathrm{ft}$.
$17.00 \quad 150.00$
3 to 4 ft
ft. ………………………..... 25.00
to 6
to 8
ft.
50.00
70.00
8 to 10
ft.
95.00

SCIADOPITYS verticillata (Umbrella Pine). 60 to

$70 \mathrm{ft}$. Good specimen pyramids with dense, shining green needles arranged like umbrella ribs around the branches.

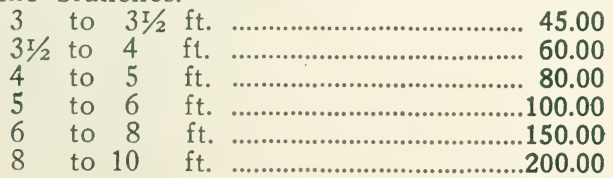


Evergreen Trees-Continued

TAXUS baccata aurea (Golden English Yew). Golden form of taxus baccata.

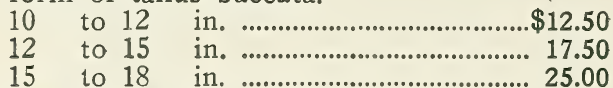

T. baccata repandens (Spreading English Yew). 2 to 3 ft. Spreading, horizontal branches, dark bluegreen foliage. Valuable for low planting.

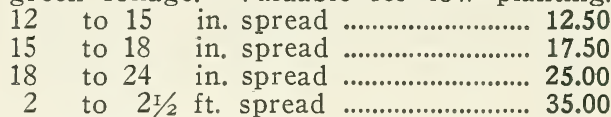

T. cuspidata (Japanese Yew). 10 to $12 \mathrm{ft}$. Most enduring is this spreading, bushy $Y$ ew with its dark green leaves covered with bright crimson fruits in the fall.

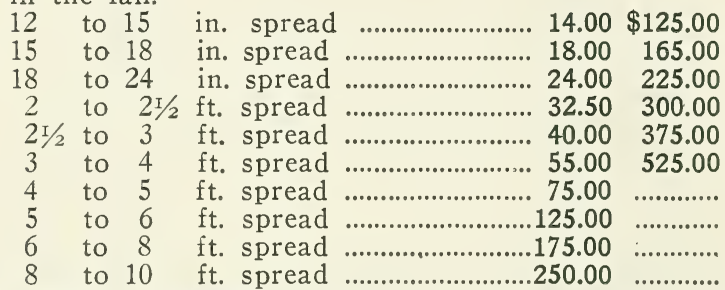

T. cuspidata capitata (Treeform Japanese Yew). 25 to $30 \mathrm{ft}$. A beautiful and symmetrical broad pyramid of darkest green.

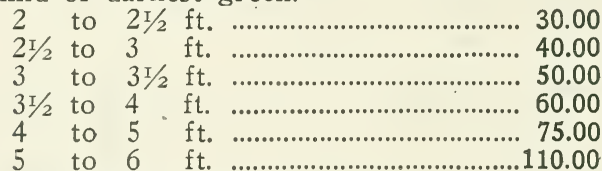

T. cuspidata intermedia (Hybrid Yew). 12 to $15 \mathrm{ft}$. Deep waxy green foliage, on a shapely, compact plant. Splendid for use as a hedge plant, also as individual specimens.
12 to 15
in.
$15.00 \quad 135.00$
15 to 18
in.
$20.00 \quad 175.00$
18 to 24
in.
25.00
to $21 / 2 \mathrm{ft}$
35.00

T. cuspidata nana (brevifolia) (Dwarf Japanese Yew). 4 to $5 \mathrm{ft}$. Slow growing, deep green foliage. A gorgeous evergreen as an individual specimen or in a mixed planting.

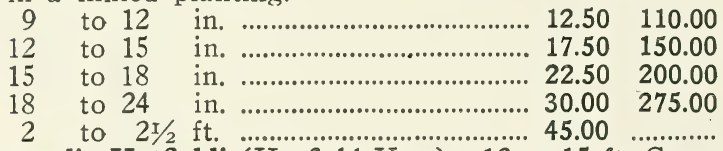

T. media Hatfieldi (Hatfield Yew). 12 to $15 \mathrm{ft}$. Compact, cone-shaped tree. Very desirable upright form.

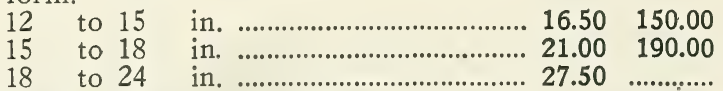

T. media hicksi (Hicks Yew). 8 to $10 \mathrm{ft}$. Narrow, columnar form, perfect for an accent plant.

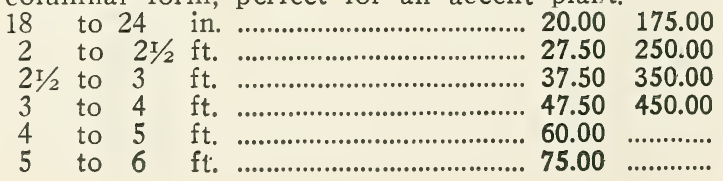


Evergreen Trees-Contimued

$10 \quad 100$

T. media kelseyi (Kelsey Yew). Slow growing upright tree. Dark green dense needles of the brevifolia type. Bright red fruits.
18 to 24 in.
$\$ 27.50$
$2 \mathrm{r} / 2$ to $3 \mathrm{ft}$.
35.00
50.00

T. media vermeulen (Vermeulen Yew). Very compact and dense, upright grower. Broad base and narrow top. Beautiful pyramid, heavily interspersed with red berries.
18 to 24 in.
27.50
2 to $21 / 2 \mathrm{ft}$.
35.00
$2 \mathrm{r} / 2$ to $3 \mathrm{ft}$.
50.00

THUJA occidentalis (American Arborvitae). 25 to $35 \mathrm{ft}$. These broad based trees, with their soft flexible deep green foliage turning bronze in winter, are equally good as windbreaks, for an evergreen hedge, or in the background of mixed plantings.

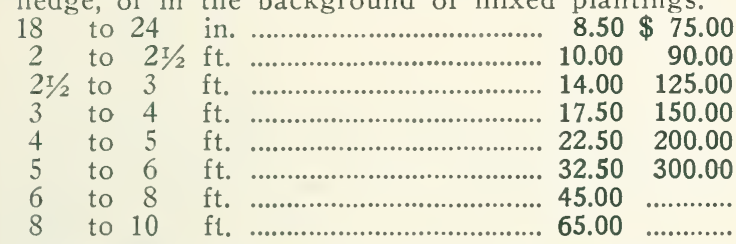

T. occidentalis compacta (Parsons Arborvitae). 3 to $4 \mathrm{ft}$. Bright green, nearly globular; good in formal garden and foundation plantings. 9 to 12
in.
$5.50 \quad 45.00$
12 to 15
15 to 18
$7.50 \quad 65.00$
18 to 24
in.
9.50
85.00

T. occidentalis elegantissima (Yellow Column Arborvitae). 10 to $15 \mathrm{ft}$. Perfectly gorgeous columns of foliage, tipped golden in summer.
18 to 24 in.
2 to $2 \mathrm{I} / 2 \mathrm{ft}$
$11.00 \quad 90.00$
$21 / 2$ to $3 \mathrm{ft}$.
$13.50 \quad 120.00$
3 to $4 \mathrm{ft}$.
17.50
ft. ......................................... 25.00
25.00
4 to 5 ft
$30.00 \quad 275.00$
6 to 8
$\mathrm{ft}$.
55.00

T. occidentalis globosa (Globe Arborvitae). 3 to 4

$\mathrm{ft}$. Perfect globes of dense, light green foliage.
9 to 12
12 to 15
in.
$5.50 \quad 45.00$
15 to 18
18 to 24
in.
$7.50 \quad 65.00$
in.
$9.50 \quad 85.00$
in.
$12.50 \quad 115.00$

T. occidentalis Hoveyi (Hovey Arborvitae). 3 to 4 ft. Bright, yellow-green ovals, nearly as broad as they are tall.
12 to 15
in.
$7.50 \quad 65.00$
15 to 18
in.
9.50

T. occidentalis lutea (George Peabody Arborvitae).

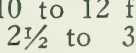
Conspicuous golden columns.
$\begin{array}{llr}21 / 2 & \text { to } & 4 \\ 3 & \text { to } & 5 \\ 4 & \text { to } & 5 \\ 5 & \text { to } & 6 \\ 6 & \text { to } 8 \\ 8 & \text { to } 10\end{array}$
$\mathrm{ft}$.
17.50
$\mathrm{ft}$.
22.50
ft.
30.00
$\mathrm{ft}$.
37.50
ft.
ft.
65.00 
Evergreen Trees-Continued

THUJA-Continued

$10 \quad 100$

T. occidentalis nigra (Dark Green Arborvitae). 20 to $25 \mathrm{ft}$. Carries very deep green foliage throughout the entire year, and is of dense, broad, pyramidal growth.
18 to 24
$\$ 10.00 \$ 90.00$
2 to $2 \mathrm{t} / 2 \mathrm{fi}$
$13.50 \quad 120.00$
$2 \mathrm{r} / 2$ to $3 \mathrm{ft}$.
$17.50 \quad 150.00$
3 to 4 ft.
$21.50 \quad 190.00$

T. occidentalis pyramidalis (Pyramidal Arborvitae). 20 to $30 \mathrm{ft}$. Best, by far, of upright Thujas. These narrow green columns are splendid for formal accents.

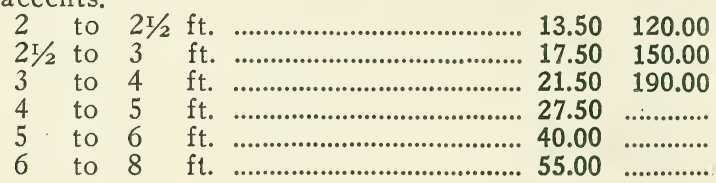

T. occidentalis rosenthali (Rosenthal Arborvitae). 8 to $10 \mathrm{ft}$. Rugged, deep green, dense columns, improving with age.
18 to 24 in.
$11.00 \quad 95.00$
2 to $2 \frac{\mathrm{T}}{2} \mathrm{ft}$.
$\begin{array}{ll}13.50 & 120.00\end{array}$
$2 \mathrm{~T} / 2$ to $3 \mathrm{ft}$
$16.50 \quad 150.00$
3 to $4 \mathrm{ft}$.
$22.50 \quad 200.00$
4 to 5
$\mathrm{ft}$.
$30.00 \quad 275.00$

T. occidentalis spiralis (Spiral Arborvitae). 10 to 15 ft. Erect and formal, but with peculiarly twisted foliage.
3 to 4
4 to 5
ft.
25.00
ft.
30.00
$\begin{array}{lll}5 & \text { to } & 6 \\ 6 & \text { to } & 8\end{array}$
$\mathrm{ft}$.
40.00
ft. .......................................... 50.00

T. occidentalis standishi (Standish Arborvitae). 25 to $40 \mathrm{ft}$. Broad pyramids; extremely hardy.
8 to 10
10 to 12
12 to 15
15 to 18
$\mathrm{ft}$.
$\mathrm{ft}$.
$\mathrm{ft}$.
75.00
100.00
150.00
200.00

T. occidentalis vervaeneana (Vervaene Arborvitae). 8 to $12 \mathrm{ft}$. Broad pyramids with variegated greenish yellow foliage, turning bronze in winter.
18 to 24
2 to $2 \mathrm{~T} / 2 \mathrm{ft}$.
8.50
$21 / 2$ to 3
3 to 4
4 to 5
5 to 6
6 to 8
in.
10.00
ft.
15.00
$\mathrm{ft}$.
20.00
ft.
25.00
ft.
35.00
50.00

T. occidentalis wareana (Ware or Siberian Arborvitae). 12 to $15 \mathrm{ft}$. Rich, glaucous, green throughout the year. Very hardy.
15 to 18
in.
8.50
75.00
18 to 24
10.00
90.00
2 to $2 \mathrm{r} / 2 \mathrm{ft}$.
15.00
$2 \mathrm{r} / 2$ to $3 \mathrm{ft}$.
20.00
3 to $4 \mathrm{ft}$.
25.00 
Evergreen TREes-Concluded

$10 \quad 100$

T. occidentalis woodwardi (Woodward Arborvitae). $3 \mathrm{ft}$. Round, bushy and compact. Difficult to detect any difference between this and "globosa."

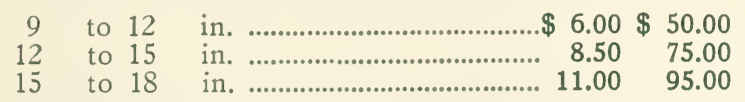

T. orientalis varieties. See Biota, pages 43 and 44 .

TSUGA canadensis (Canada Hemlock). 75 to $85 \mathrm{ft}$. Good for specimens or clipped hedge. Slender, pendulous branclies and rich, deep green foliage.

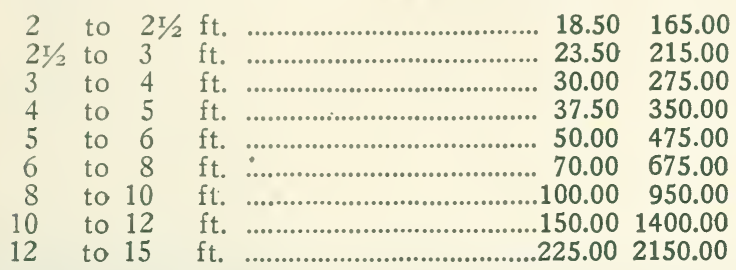

T. canadensis pendula (Sargent Weeping Hemlock). 7 to $\mathrm{S} \mathrm{ft}$. The famous Sargent Weeping Hemlock, a lovely lawn specimen. Many times broader than high.
$31 / 2$ to 4
4 to 5
ft. spread, h'y sp'c'm'ns.. 75.00
5 ft. spread, h'y spc'm'ns.. 100.00
5 to 6 ft. spread, h'y spc'm'ns..150.00
6 to 8 ft. spread, h'y spc'm'ns..225.00

T. caroliniana (Carolina Hemlock). 40 to $50 \mathrm{ft}$. Native sort, slower in growth than the Canada Hemlock, but equally attractive.
$21 / 2$ to 3
$\mathrm{ft}$.
27.50
3 to $4 \mathrm{ft}$.
35.00
4 to 5
ft.
45.00
5 to 6
$\mathrm{ft}$.
60.00

I received the shipment of Evergreens on April 10 th, in fine condition.
WALTER E. JOHNS, Gettysburg, $\mathrm{Pa}$.

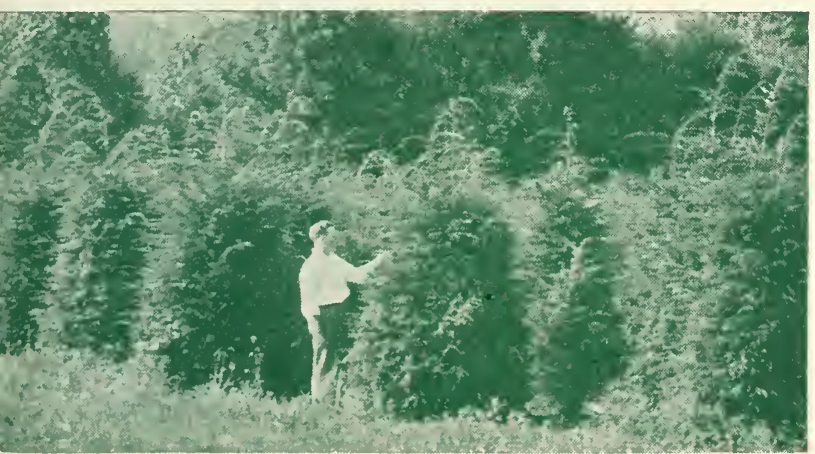

A few of our larger Canadian Hemlocks. 
Hardy Perennial Plants-Contimued

ACHILLEA filipendulina (Fernleaf Yarrow). 2 to $3 \mathrm{ft}$. Golden, summer floral heads. This is a splendid variety for production of cut flowers, and also for planting in a perennial border.

From 21/4 in. pots .................................. $.80 \$ 6.00$

A. ptarmica, "Boule de Neige." 15 to 18 in. White, double flowers, excellent for cutting during July and August. .............................................. $1.20 \quad 10.00$ From 21/4 in. pots .................................... $1.00 \quad 8.00$

A. ptarmica (Perry's White). $11 / 2$ to $2 \mathrm{ft}$. July-August. Pure white flowers with broad, overlapping petals. Good for cutting. ................................... $1.20 \quad 10.00$ From 21/4 in. pots .................................... $1.00 \quad 8.00$

ACONITUM sparksi (Spark's Monkshead). $4 \mathrm{ft}$. Exceptionally attractive in a shady location, with a wealth of deep purplish-blue flowers in late summer.

$$
2.00 \quad 17.50
$$

AEGOPODIUM podograria variegatum (Bishop Weed). $8 \mathrm{in.}$ White flowers in the spring from attractively white-margined leaves. A splendid border plant. (R). From $2 \frac{1}{4}$ in. pots. $1.00 \quad 8.00$

AGROSTEMMA coronaria. $2 \mathrm{ft}$. Brilliant purplecrimson flowers and silvery foliage. .... $1.00 \quad 8.00$

AJUGA reptans (Carpet Bugle). 6 to 8 in. Prostrate, with blue flowers from attractive foliage in May and June. A splendid "ground cover" plant. (R). From 21/4 in. pots. ......................... $1.00 \quad 8.00$

ALYSSUM saxatile compactum (Basket of Gold). 9 to 12 in. Bright yellow flowers, over silvery foliage, in very early spring. (R). ...... $1.10 \quad 9.00$

ANCHUSA italica, Dropmore. 4 to $5 \mathrm{ft}$. Spikes of velvety blue in June and July. Makes a good cut flower, but needs winter protection. .... $1.20 \quad 10.00$

ANEMONE hupehensis (Dwarf Anemone). 12 to 18 in. Attractive, mauve-rose flowers from late August to mid-October. (R). ............. $1.80 \quad 15.00$

A. japonica alba. $2 \mathrm{ft}$. Pure white with golden stamens. Fall. ............................................ $1.80 \quad 15.00$

A. japonica, Queen Charlotte. $2 \mathrm{ft}$. Pink; semidouble. Fall. .......................................... 2.00

A. japonica, Whirlwind. $2 \mathrm{~T} / 2 \mathrm{ft}$. White; very double.

A. pulsatilla (Pasqueflower). 8 to 10 in. Purplishblue flowers in very early spring. Extra hardy.

$$
1.8015 .00
$$

ANTHEMIS tinctoria, Perry's Variety. 2 to $2 \mathrm{~T} / 2 \mathrm{ft}$. Good for cutting, with flowers like big, yellow, semidouble daisies in late summer. ............ $1.20 \quad 10.00$

AQUILEGIA alpina. $1 \mathrm{I} / 2$ to $2 \mathrm{ft}$. Deep blue flowers with white corolla, in June. Makes a lovely cut flower. (R). ............................................. $1.50 \quad 12.00$

A. canadensis (American Columbine). $11 / 2 \mathrm{ft}$. Red and yellow. Our native variety. (R). $\begin{array}{lll}1.20 & 10.00\end{array}$

A. chrysantha (Golden Columbine). 2 ft. Goldflowered, spurred sort. (R). ................ $1.20 \quad 10.00$

A. Crimson Star. 15 to 18 in. Flowers very large with crimson sepals and spurs, and white petals; an entirely new color in Aquilegias. Free flowering. ( $R$ ).

1.80

A. SILVER QUEEN. $2 \mathrm{ft}$. Flesh pink buds turn to glistening, silvery white flowers with beautiful long spurs. (R). ..................................... $1.80 \quad 15.00$ 
Hardy Perendial Plants-Continued

AQUILEGIA-Concluded 10100

A. Mrs. Scott Elliott's Choice Long-spurred Hybrids. 2 to $3 \mathrm{ft}$. A wonderful color range appears on these famous, extra long-spurred, sorts. ....\$ $1.20 \$ 10.00$

ARABIS alpina (Rockcress). 6 to 8 in. Pure white flowers in very early spring. (R). From $21 / 4$ in. pots. $1.00 \quad 8.00$

ARMERIA Bee's Ruby. 18 in. Bright red flowers, about two inches in diameter and splendid for cutting. Needs winter protection. ...... $1.80 \quad 15.00$

A. Formosa (Tall Thrift). 12 in. Shades of pink. Summer. (R). ........................................ $1.50 \quad 12.00$ From 21/4 in. pots. ........................................ $1.10 \quad 9.00$

A. maritima laucheana (Rosalie Thrift). 4 to 6 in. Pink flowers, rising from grassy tufts, from May to August. Extremely hardy. (R).... $1.50 \quad 12.00$

ARTEMISIA lactiflora (White Mountain-fringe). 4 to $5 \mathrm{ft}$. Fragrant white flowers, splendid for cutting, in late summer. ................................. $1.20 \quad 10.00$

A. Silver King (Ghost Plant). $2 \mathrm{I} / 2$ to $3 \mathrm{ft}$. A misty foliage seems frosted with silver. Beauliful, intermingled with cut flowers, for bouquets. Attractive when dried; therefore frequently used for winter house decorations, and for making blankets and wreaths. ...................................................... $1.20 \quad 10.00$ From 21/4 in. pols. ................................ $1.00 \quad 8.00$

ASCLEPIAS tuberosa (Butterfly Flower). $2 \mathrm{ft}$. Attractive orange flowers in late summer. Makes $\begin{array}{llll}\text { a very attractive cut flower. .................. } & 1.20 & 10.00\end{array}$ ASTER alpinus superbus, Goliath. 12 to 15 in. Purple-blue. Late spring. (R). From 3 in. pots. 1.80

\section{ASTERS-Named Sorts}

\section{$2 \mathrm{I} / 2$ to $3 \mathrm{ft}$. Late Summer and Fall.}

Anita Ballard. Double; clear Petunia violet. A very good variety. ............................................ $1.50 \quad 12.00$ From 21/4 in. pots. ...................................... $1.10 \quad 9.00$

Blue Beard. Blue, creamy center. ....... $1.50 \quad 12.00$

Blue Bird. A profusion of bright colored, clear blue flowers of extra large size. From $2 \mathrm{I} / 4$ in. pots.

Feltham Blue. Aniline blue. ................... $1.100 \quad 9.00$ From 21/4 in. pots. ................................... $1.10 \quad 9.00$

Louvain. Delicate pink flowers, the best of their color. ......................................................... $1.50 \quad 12.00$

From 21/4 in. pots. ...................................... $1.10 \quad 9.00$

Novibelgi, Climax. Light, lavender blue. $1.50 \quad 12.00$ From 21/4 in. pots. .................................. $1.10 \quad 9.00$

Palmyra. Medium height. Pure pink, semi-double. A very choice variety. ............................ $1.80 \quad 15.00$ From 2I/4 in. pots. .................................. $1.50 \quad 12.00$

St. Egwin. $2 \frac{1}{2}$ ft. Light pink, compact. medium height. ................................................... 1.5012 .00 From 21/4 in. pots. .................................. $1.10 \quad 9.00$

Sunset Glow. Bright deep pink. Early September. $1.50 \quad 12.00$ From 21/4 in. pots. ................................ $1.10 \quad 9.00$

White Climax. Produces extra large, single white flowers in September and early October.

White Queen. A valuable and beautiful Aster with countless white blooms. 
Hardy Perexinal Plants-Continued

ASTER SPECIES

10100

Aster novae-angliae (New England Aster). $4 \mathrm{ft}$. Extremely hardy and, from September to November, produces vast quantities of attractive, rather large purplish-blue flowers.

$\$ 1.20 \$ 10.00$

A. novae-angliae rosea. $+\mathrm{ft}$. Large, deep pink flowers. Sept.-Nov. ....................................... $1.50 \quad 12.00$

A. tataricus (Tatarian Aster). 5 to $6 \mathrm{ft}$. Violet-blue. Late fall. Good for cutting. ................ $1.50 \quad 12.00$

(R) HARDY DWARF ASTERS (R)

These immensely valuable new Asters have come into great popularity for rockeries, for edging, and for groups in front of taller borders.

Constance. 9 in. Pure shell-pink, a delightful color; of graceful habit. September. ............... $1.80 \quad 15.00$ From 21/4 in. pots. .................................... $1.20 \quad 10.00$

Countess of Dudley. 9 in. Charming clear pink flowers with yellow eye; of bushy habit and free flowering. Late September. ............................. $1.80 \quad 15.00$

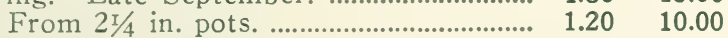

Lady Henry Maddocks. 10 in. Many pale pink blooms. ......................................................... $1.80 \quad 15.00$

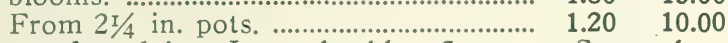
Lavanda. 6 in. Lavender-blue flowers. September. $\begin{array}{lll} & 1.80 & 15.00\end{array}$ Lilac Time. 12 in. Clear lilac flowers. September.

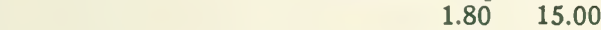
From 21/4 in. pots. .................................. $1.20 \quad 10.00$ Snowsprite. 10 in. Best white dwarf Aster. Early September. ................................................ $1.80 \quad 15.00$ From 21/4 in. pots. ..................................... $1.20 \quad 10.00$

Victor. 8 in. Clear lavender-blue; very dwarf. Early September. ..................................................... $1.80 \quad 15.00$ From 21/4 in. pots. ........................................ 1.2010 .00

\section{ASTIBLE}

$1 \mathrm{I} / 2$ to $2 \mathrm{~T} / 2 \mathrm{ft}$.

These lovely plants will make your customer's garden a spot of extreme beauty in mid-summer. They are perfect for forcing.

All Strong, 2 yr. plants, suitable for forcing.

America. Lilac. ............................................ $2.20{ }^{1} 18.00$ Granat. Strong flowering spikes of deep crimson red. A gorgeous sort. .......................................... $2.20 \quad 18.00$ Peach Blossom. Clear pink, graceful, early.

Clear ligint $2.20 \quad 18.00$ 2.2018.

BAPTISIA australis (IVild-Indigo). 3 fi. 25.00 spikes of deep blue flowers in May and June. Makes a splendid cut flower. ............................... $1.50 \quad 12.00$ BOCCONIA cordata (Pink Plumepoppy). 6 to $8 \mathrm{ft}$. Creamy white. Late summer. ............. 1.5012 .00 BOLTONIA asteroides (White Starwort). 5 to $6 \mathrm{ft}$. White daisy-like flowers in abundance during August and early September. .............. $1.20 \quad 10.00$

CAMPANULA carpatica (Carpathian Harebell). 8 in. Forms compact tufts and produces attractive clear blue flowers, on wiry stems, almost continuously from June until October. A splendid edging plant for the hardy border, also for the rockery.

From $2 \frac{1}{4}$ in. pots. 
Hardy Perennial Plants-Continued

CAMPANULA-Concluded

$10 \quad 100$

C. medium (Canterbury-bells). 2 to $3 \mathrm{ft}$. Popular, with its attractive bell-shaped bloom in June and July. We offer separate colors, Blue, pink or white. $\$ 1.20 \$ 10.00$

C. persicifolia (Peachleaved Bell Flower). 2 ft. Big cupped blue flowers in June and July. 1.5012 .00

CATANANCHE caerulea (Blue Cupidsdart). $11 / 2 \mathrm{ft}$. Deep blue flowers on long stems, from July until frost. These attractive blue flowers are often dried and used for winter bouquets.

1.50

CENTAUREA macrocephala (Globe Centaurea). $3 \mathrm{ft}$. Yellow thistle-like flowers in late summer.

\begin{tabular}{ll}
$1.50 \quad 12.00$ \\
\hline
\end{tabular}

C. montana (Perennial Cornflower). 18 in. The attractive blue flowers are borne in late summer and are splendid for cutting. .......................... $1.20 \quad 10.00$

CERASTIUM biebersteini (Taurus Cerastium). 12 in. White flowers in early summer, and silvery foliage throughout the year. A good ground cover plant. (R).

$1.20 \quad 10.00$

CHRYSANTHEMUM-Species:

arcticum (Arctic Daisy). 12 to 18 in. Bushy mounds of large, white, daisy-like flowers in

August and September. ......................... $1.50 \quad 12.00$ From 21/4 in. pots. ............................... $1.10 \quad 9.00$ coreanum (Korean Chrysanthemum). $21 / 2$ to $3 \mathrm{ft}$. Blush white. September to frost. .... $1.50 \quad 12.00$ maximum (Shasta Daisy). $2 \mathrm{ft}$. Super daisies during the entire summer and early fall.

$1.20 \quad 10.00$

\section{CHRYSANTHEMUMS-Named:}

Buttercup. One of the best of the large yellowflowered sorts. ....................................... $1.50 \quad 12.00$

Cheerfulness. Many yellow buttons. .... $1.50 \quad 12.00$

Chestnut Burr. Many big double flowers of rich chestnut red. ....................................... $1.80 \quad 15.00$

Clara Curtis. Beautiful single flowers which are a delightful shade of rose-pink. ........ $1.50 \quad 12.00$

Cometo. Large, mauve-pink Pompon. 1.5012 .00

CUSHION MUMS. These popular, compact growing plants produce great quantities of flowers in mid-summer. Pink, White, Bronze, Red, separate colors. ........................................... $1.50 \quad 12.00$

Field of Snow. White bud with pinkish tinge. Of rather dwarf growth. ......................... $1.50 \quad 12.00$

Harvard. Dark crimson, large flowered sort.

$\begin{array}{rrr}1.50 & 12.00\end{array}$

Irene. Best white button Mum. ........ $1.50 \quad 12.00$

L'Argentuillais. Scarlet-bronze. Large. 1.80 .............

Norine. Big sprays of yellow Pompons. Blooms late in the season, but is extremely hardy.

October Beauty. Big semi-double, bronze.

$1.50 \quad 12.00$

Red Indian. One of the hardiest of all Chrysanthemums, and produces its flowers late in the season. ……......................................... $1.50 \quad 12.00$

Wm. Buckingham. Semi-double pink blooms, centered yellow. Of tall growth. .......... $1.50 \quad 12.00$

Yellow Normandie. A splendid, tall growing, large, yellow-flowered sort which blooms late in the season. 
Hardy Perennial Plants-Contimued

\section{HARDY KOREAN CHRYSANTHEMUMS}

These attractive hybrids continue to remain extremely popular. We can supply strong plants of each of the following sorts.

All varieties have golden yellow centers.

Astrid. $2 \mathrm{ft}$. Semi-double, pink.

Ceres. $2 \mathrm{ft}$. Coppery-bronze.

Daphne. $3 \mathrm{ft}$. Soft pink.

Good Morning. $2 \mathrm{ft}$. Creamy yellow.

Jacqueline. $2 \frac{1}{2} \mathrm{ft}$. Lavender-pink.

Lorene. $21 / 2 \mathrm{ft}$. Pure light pink.

Mars. 21/2 ft. Velvety wine-red.

Vonnie. $2 \frac{1}{2} \mathrm{ft}$. Pinkish purple.

All varieties, $\$ 1.50$ per $10 ; \$ 12.00$ per 100 .

HARDY KOREAN CHRYSANTHEMUMS, assorted. Our assortment of these Korean Mums is unbelievably large, yet each flower is a separate triumph. Mixed colors. ....................\$ $1.00 \$ 8.00$

CHRYSOBOLTONIA pulcherrima (September Daisy.) $2 \mathrm{I} / 2 \mathrm{ft}$. Beautiful rose-pink, daisy-type flowers from mid-October until late September. $2.00 \quad 18.00$

CLEMATIS davidiana (Fragrant Tube Clematis). 2 to $3 \mathrm{ft}$. Many fragrant bell-shaped flowers of deep lavender-blue, in late summer. Very hardy, and splendid from every viewpoint. ........... $2.00 \quad 18.00$

C. recta (Ground Clematis). $3 \mathrm{r} / 2$ ft. Big, showy clusters of fragrant white bloom, in early summer. $1.80 \quad 15.00$

CONVALLARIA majalis (Lily-of-the-Valley). 8 to 10 in. Exceptionally popular; with sprays of fragrant waxy white flowers in late Spring. Best in shade. (R). 3 in. clumps. .................. $1.70 \quad 14.00$

COREOPSIS grandiflora florepleno (Big Double Coreopsis). 2 to $3 \mathrm{ft}$. Large, double yellow. From July to late September. ........................ $1.20 \quad 10.00$

C. lanceolata (Lance Coreopsis). 2 to $3 \mathrm{ft}$. Golden yellow. Early summer to frost. ....... $1.00 \quad 8.00$

DELPHINIUM Belladonna (Blue Larkspur). $4 \mathrm{ft}$. Sky blue. Late spring to frost. ........... $1.50 \quad 12.00$ From 21/4 in. pots. ................................. $1.10 \quad 9.00$

D. Bellamosum (Deep Blue Larkspur). $3 \mathrm{ft}$. Very dark blue. Late spring to frost. ......... $1.50 \quad 12.00$ From 21/4 in. pots. ............................... $1.10 \quad 9.00$

D. chinense (Slender Larkspur). 18 in. Gentian blue flowers throughout summer. ................ $1.50 \quad 12.00$

D. Pacific Hybrids. 3 to $5 \mathrm{ft}$. Flowers large, of delicate shades in blue, lavender and white. This is the finest strain of Hybrid Delphiniums with which we are familiar. .......................... $1.80 \quad 15.00$ From $21 / 4$ in. pots. ................................ $1.20 \quad 10.00$

\section{DIANTHUS (PINKS)}

Abbottsford. $1 \mathrm{ft}$. Big crimson flowers with markings of white. An old favorite. ......... $1.50 \quad 12.00$

Barbatus (Sweet-William). $1 \mathrm{I} / 2 \mathrm{ft}$. Mixed colors: Pink, red, and white. May. (R). From 21/4 in. pots.

Beatrice. $1 \mathrm{ft}$. Salmon-rose, fragrant flowers from spring to frost. (R). From $2 \frac{1}{4}$ in. pots. 
Hardy Perennial Plants-Continued

\section{DIANTHUS-Concluded $\quad 10 \quad 100$}

Deltoides (Maiden Pink). 8 in. Prostrate. Easily grown; with crimson flowers in June and July. (R). From $2 \mathrm{r} / 4$ in. pots. .....................................\$ $1.00 \$ 8.00$

Furst Bismarck. 8 in. An old favorite, which is deeper in color than the popular variety, Beatrice. (R). .......................................................... $1.50 \quad 12.00$ From 21/4 in. pots. .................................. $1.10 \quad 9.00$

Grenadin (Hardy Carnations). 15 to 18 in. These beautiful hardy Pinks bloom throughout the entire summer. Separate colors: Red, pink and white.

$\begin{array}{ll}1.50 & 12.00\end{array}$

Semperflorens (Perpetual Pinks). 10 to 12 in. Fragrant semi-double pink. Summer. (R).

$1.20 \quad 10.00$

Silvermine. 10 in. Double white, all summer. (R). From 21/4 in. pots. ..................................... $1.50 \quad 12.00$

DICENTRA eximia (Fringed Bleedingheart). 12 in. Beautiful pink flowers from May to September. Attractive fern-like foliage. (R). ........ $1.50 \quad 12.00$

D. spectabilis (Bleedingheart). 2 to $2 \frac{1}{2} \mathrm{ft}$. Rosy crimson. spring. Selected, 2 yr. roots. 2.5020 .00

DICTAMNUS fraxinella rubra (Gasplant). $21 / 2 \mathrm{ft}$. Rosy pink. Early summer. ................... $1.70 \quad 14.00$

DIGITALIS gloxiniaeflora (Foxglove). $4 \mathrm{ft}$. Purple and white. June and July. ..................... $1.20 \quad 10.00$

D. Isabellina (New). 3 to $4 \mathrm{ft}$. Yellow flowers from July to frost. This is an extremely hardy sort.

$$
\begin{array}{lll} 
& 1.50 & 12.00
\end{array}
$$

From 21/4 in. pots. .................................. $1.00 \quad 8.00$

ECHINOPS ritro. 4 to $5 \mathrm{ft}$. Metallic blue flowers, thistle-like foliage. ................................... $1.20 \quad 10.00$

ERIGERON speciosus (Oregon Fleabane). $2 \mathrm{ft}$. Violet-blue flowers, centered yellow, from early July until mid-August. ........................... $1.80 \quad 15.00$

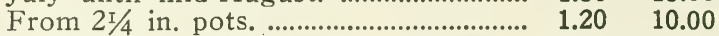

ERYNGIUM amethystinum (Amethyst Seaholly). 2 to $3 \mathrm{ft}$. Blue thistles in mid-summer, from silver stems.

1.2010 .00

EUPATORIUM coelestinum (Mistflower). $2 \mathrm{ft}$. Beautiful celestial blue flowers, similar in appearance and general character to the bedding plant, Ageratum. August to October. ........... 1.50 12.00

EUPHORBIA myrsinites. 6 to 8 in. Trailing, with silvery-gray foliage, and yellow flowers. June. (R). $1.80 \quad 15.00$

E. polychroma. $1 \mathrm{ft}$. Yellow flowers in May and June. $1.80 \quad 15.00$

FUNKIA caerulea (Blue Plantainlily). $11 / 2$ to $2 \mathrm{ft}$. Blue. July to August. ............................. $1.20 \quad 10.00$

F. lancifolia undulata variegata (Wavyleaf PlantainLily). 12 to 15 in. Blue flowers and very attractive variegated leaves. Late summer. $1.20 \quad 10.00$

F. sieboldiana (Cushion Plantainlily). 18 to $24 \mathrm{in.}$ Lilac tinged white flowers in mid-summer.

$1.20 \quad 10.00$

F. subcordata grandiflora (Great White Plantainlily). 18 to 24 in. Large, white lily-like flowers are produced over broad, attractive foliage during July and August. 
Hardy Perennial Plants-Contimued

$10 \quad 100$

GAILLARDIA Goblin. 12 to 15 in. A new Gaillardia which is especially suitable for rockeries. Broad bushes, close and compact, are covered by the red and yellow flowers from June until frost.

$\$ 1.50 \$ 12.00$

G. grandiflora (Perennial Gaillardia). 18 in. The large, orange to maroon, daisy-like flowers are borne all summer. .............................. $1.20 \quad 10.00$

GEUM, Mrs. Bradshaw. Large, double flowers of a fiery orange-red. Splendid for cutting. $\quad \begin{array}{ll}1.50 & 12.00\end{array}$

\section{Ornamental Grass}

EULALIA gracillima (Maiden Grass). $6 \mathrm{ft}$. Narrow, deep green leaves with white mid-rib.

$1.50 \quad 12.00$

E. japonica (Japanese Eulalia). 6 to $7 \mathrm{ft}$. Silvery plumes above deep green foliage. ....... $1.50 \quad 12.00$

E. japonica variegata (Striped Eulalia). 5 to $6 \mathrm{ft}$. Striped lengthwise white, yellow and pale green.

$$
\begin{array}{ll}
1.50 & 12.00
\end{array}
$$

E. japonica zebrina (Zebra Grass). 7 to $8 \mathrm{ft}$. Silver plumes above blades which are broadly striped yellow across the leaves. ..................... $1.80 \quad 15.00$

FESTUCA glauca (Kentucky Blue Grass). 8 to 10 in. Blue tufts of fine grass. .......... $1.20 \quad 10.00$

PENNISETUM japonicum (Fountain Grass). $4 \mathrm{ft}$. Bronzy-purple flower heads, and attractive foliage.

$1.50 \quad 12.00$

GYPSOPHILLA, "Bristol Fairy." 2 to $3 \mathrm{ft}$. Panicles of double white flowers all summer. A splendid cut flower.

$$
2.50
$$

G. oldhamiana (Pink Babys Breath). 2 to $3 \mathrm{ft}$. A long-flowering pink sort which is the best of its color. ................................................... $1.50 \quad 12.00$

G. paniculata (Babys Breath). $3 \mathrm{ft}$. Gauzy white flowers produced in large sprays in mid-summer.

From 21/4 in. pots. .............................. $1.00 \quad 8.00$

HELENIUM "Riverton Gem." 3 to $4 \mathrm{ft}$. Old gold flowers, suffused terra cotta and turning to wallflower red. August and September. .... $1.50 \quad 12.00$

HELIANTHEMUM croceum (Sunrose). 6 in. Large flowers of gold in late summer. (R).

$$
1.20 \quad 10.00
$$

NEW HELIANTHEMUMS. 6 in. We can offer these charming Sun Roses in the following separate colors: Apricot, Flame, Orange and White.

$$
1.50 \quad 12.00
$$

HELIANTHUS Miss Mellish (Sunflower). 5 to 6 ft. Large, single, golden flowers during August and September. .................................... $1.20 \quad 10.00$

H. mollis (Ashy Sunflower). $4 \mathrm{ft}$. Large pale yellow. Mid-summer. ........................... $1.50 \quad 12.00$

H. multiflorus fl. pl., "Soleil d'Or." $4 \mathrm{ft}$. Clear yellow flowers, like small Dahlias. August and September. Should have winter protection.

$1.50 \quad 12.00$

H. sparcifolius (Hardy Sunflower). $5 \mathrm{ft}$. Extra large, single, yellow flowers. August and September. 
Hardy Perennial Plants-Contimued

10100

HELIOPSIS pitcheriana (Pitcher Heliopsis). 3 to $4 \mathrm{ft}$. Deep golden, rather large, daisy-like flowers which are splendid for cutting. $\$ 1.20 \$ 10.00$

H. scabra excelsa fl. pl. (Rough Heliopsis). 3 to $4 \mathrm{ft}$. Double yellow. Late summer. ............ $1.50 \quad 12.00$

HEMEROCALLIS aurantiaca (Orange Daylily). 3 ft. Huge, bright orange flowers. July. 1.2010 .00 H. Dr. Regel. $21 / 2$ to $3 \mathrm{ft}$. Rich deep golden Lilies. June and early July. ............................... $1.20 \quad 10.00$

H. dumortieri (Early Daylily). $2 \mathrm{ft}$. Bright yellow. May and June. ......................................... $1.20 \quad 10.00$

H. Gold Dust. $2 \mathrm{r} / 2 \mathrm{ft}$. Yellow, tinted red. Early summer. ........................................................ $1.20 \quad 10.00$

H. Kwanso fl. pl. (Double Daylily). 3 to $4 \mathrm{ft}$. Double, copper-yellow. July and August. ........ $1.20 \quad 10.00$

LOVETT'S LEMON. 3 to $4 \mathrm{ft}$. Largest lemoncolored variety of which we have any knowledge. A truly glorious sort. Early August until late September. ................................................. $1.50 \quad 12.00$

LOVETT'S ORANGE. 3 to $4 \mathrm{ft}$. A rather tall growing sort with extra large orange flowers in late summer.

$\begin{array}{ll}1.50 & 12.00\end{array}$

H. Mikado. 21/2 to $3 \mathrm{ft}$. Mellow orange. Each petal has an area of dark red purple. July to early September. ................................................ $3.00 \quad 25.00$

H. Orangeman. Orange-yellow, early summer. $1.20 \quad 10.00$

H. Pale Moon. 3 to $4 \mathrm{ft}$. Pale glistening yellow, July and August. .................................. $3.50 \quad 30.00$

H. thunbergi (Japanese Daylily). 3 to $4 \mathrm{ft}$. Bright gold. September. .................................... $1.20 \quad 10.00$

HEUCHERA pluie de Feu. 15 to 18 in. Deep coralred bells on slender stems. Requires winter protection.

$\begin{array}{ll}1.80 & 15.00\end{array}$

H. rosamundi (Pink Coral Bells). 18 in. Best by far of the coral-pink Heucheras, with an abundance of lasting blossoms on strong stems in early summer. .................................................... $1.50 \quad 12.00$ From 21/4 in. pots. ................................... $1.10 \quad 9.00$

HIBISCUS, Meehan's Mallow Marvels. $5 \mathrm{ft}$. Crimson to white, mixed colors. Late Summer to midfall. ......................................................... $1.00 \quad 8.00$

H. Crimson. $5 \mathrm{ft}$. Solid crimson, gorgeous.

$1.50 \quad 12.00$

H. Pink. $5 \mathrm{ft}$. Large bright pink flowers.

1.2010 .00

HOLLYHOCKS, Double. 6 to $8 \mathrm{ft}$. Pink, Maroon, Red, Salmon, Yellow, White and Mixed.

$1.20 \quad 10.00$

IBERIS sempervirens (Evergreen Candytuft). 8 to 10 in. Glistening white flowers, produced over attractive evergreen foliage in early spring. ( $R$ ).

1.5012 .00

From 21/4 in. pots.

$1.00 \quad 8.00$ 
Hardy Perennial Plants-Continued

IRIS GERMANICA (German or Liberty Iris). 2 to

$3 \mathrm{ft}$. May and early June.

The following varieties at $\$ 0.70$ per $10, \$ 5.00$ per 100 .

Charles Dickens. Light violet.

Darius. Lemon yellow, veined chocolate.

F. Bernet. Bright yellow.

Florentine Alba. Porcelain to white.

H. Cramer. Celestial blue.

Pauline. Bright blue.

Pecutem. II hite.

Purple Queen. Rich purple.

Queen of May. Bright rosy lilac.

Rebecca. Golden.

The following varieties at $\$ 0.80$ per $10, \$ 6.00$ per 100 .

Agamemnon. White, edged azure blue.

Alcazar. Mauve.

Chas. Wheeler. Cream.

King. Clear lemon yellow, veined crimson.

Mme. Chereau. White, edged violet-lavender.

Mrs. Charles Darwin. White, striped blue and white.

Pallida Dalmatica (Dalmatica). Light lavender. 10100

IRIS kaempferi (Japanese Iris). 3 to $4 \mathrm{ft}$. Big flowers in early summer.

Dorothy. Six blue petals, splashed white.

$$
\$ 1.50
$$

Eleanor Parry. Claret red flamed with white and blue.

$1.50 \$ 12.00$

Fanny Hamlet Childs. Double, violet-purple, mottled and splashed white. ..................... $1.80 \quad 15.00$

Gold Bound. Best double white. ........ $1.50 \quad 12.00$

La Favorite. Double, large, white veined blue, purple center.

Mahogany. Rich velvety maroon. Blooms late.

$1.80 \quad 15.00$

MICHAEL JACOBS. Double, dark blue, with yellow base center. ...................................... $3.50 \quad 30.00$

Patrocle. Single; superb. dark violet 1.5012 .00

Purple and Gold. Double. Rich violet-purple, with conspicuous gold throat. .................... $1.20 \quad 10.00$

Pyramid. Double; indigo blue, veined white.

$\begin{array}{lll}\text { Stella Single; violet, veined white } & 1.20 & 10.00\end{array}$

Subotai. Single; a fine dark rosy-red. $1.80 \quad 15.00$

Templeton. Shapely, double flowers of reddish violet, marbled white. ........................ $1.50 \quad 12.00$

Thomps Lovett. Violet with gold band at base. Distinctive and beautiful. ................... $1.80 \quad 15.00$ IRIS kaempferi (Japanese Iris). Mixed. A superb combination of the finest blood in the Iris family. $\begin{array}{lll}\text { Per } 1000, \$ 60.00 \quad .80 & 7.00\end{array}$

I. laevigata (Rabbit-ear Iris). 18 to 20 in. Six petals, of deep blue and white, grace this Iris. MidJune. (R). ................................................ $2.20 \quad 18.00$

I. pseudacorus (Yellowflag Iris). $4 \mathrm{ft}$. Tall, with golden-yellow flowers in June. ............. $1.20 \quad 10.00$

I. pumila (Crimean Dwarf Iris). 6 to 8 in. Both of these varieties of Iris pumila bloom in very early spring, sometimes in late winter.

Blue Jay. Clear deep blue. (R). ........ $1.00 \quad 8.00$ Canary Bird. True canary yellow. (R). $1.00 \quad 8.00$

I. ochroleuca (Yellowband Iris). $3 \mathrm{ft}$. Splendid for very early cut flowers, as these lovely Iris produce blooms on tall stems throughout the month of June. Separate colors.

Cream, white and lavender. 
Hardy Perennial Plants-Continued

IRIS-Concluded

$10 \quad 100$

I. Shilka. 18 in. Amazingly hardy and with a dozen or more lovely flowers at one time on the same slender stem. Mildly fragrant. Blooms of orchid, blue and cream.

$\$ 1.80 \$ 15.00$

I. sibirica (Siberian Iris). $2 \mathrm{ft}$.

Blue King. Large, rich blue flowers. $1.20 \quad 10.00$ Orientalis. Violet-colored blooms. .... $1.00 \quad 8.00$ Snow Queen. Snowy white, shapely. 1.20 . 10.00

LATHYRUS Pink Beauty. A prostrate plant with climbing tendencies, bearing large racemes of rosepink sweet pea-like flowers all summer. 1.50

L. White Pearl. White flowered form of the above. 1.50

LIATRIS pycnostachya (Cattail Gayfeather). 4 to $5 \mathrm{ft}$. Long narrow spikes of attractive purple flowers in late summer.

L. scariosa (Showy Gayfeather). $3 \mathrm{ft}$. Startling purple flower heads in July and August.

$1.50 \quad 12.00$

L. September Glory. 4 to $5 \mathrm{ft}$. Extra long spikes of unusual, and most attractive, purple flowers in September.

LILIUM henryi (Henry Lily). 3 to $4 \mathrm{ft}$. Yellow. Late summer. ......................................... 2.50 ............

L. tigrinum florepleno (Double Tiger Lily). $5 \mathrm{ft}$. Orange, black spots. Late summer. .... $2.50 \quad 20.00$

L. umbellatum (Sweet Orangecup Lily). 18 to 24 in. Bears many pale red-orange flowers in May and June. ......................................................... $2.50 \quad 20.00$

LINUM perenne (Blue Flax). 18 in. In July and August produces deep blue flowers, which remain closed most of each day and open late in the afternoon. Should have winter protection. (R).

$\begin{array}{ccc}1.00 & 8.00\end{array}$

L. perenne album (White Flax), 18 in. White form of the above. (R). ............................... $1.00 \quad 8.00$

LOBELIA cardinalis (Cardinal Flower). $3 \mathrm{ft}$. Bright red blooms in late summer. Thrives in wet locations. From $2 \mathrm{I} / \mathrm{4}$ in. pots. ......................... $1.20 \quad 10.00$

LUPINUS polyphyllus (Blue Lupine). 3 to $4 \mathrm{ft}$. Blue. May and June. .................................. $1.50 \quad 12.00$

L. polyphyllus albus (White Lupine). 3 to $4 \mathrm{ft}$. White. May and June. ............................. $1.50 \quad 12.00$

L. polyphyllus moerheimi (Pink Lupine). 3 to $4 \mathrm{ft}$. Pink. May and June. ............................ $1.50 \quad 12.00$

L. Russell Hybrids. $4 \mathrm{ft}$. Best of all Hybrid Lupines, with an unprecedented range of color. $1.80 \quad 15.00$

LYSIMACHIA clethroides (Clethra Loosestrife). 2 ft. Attractive creamy white spikes in July and August. A good cut flower. ................. $1.20 \quad 10.00$

LYTHRUM roseum superbum (Rose Lythrum). 4 to $5 \mathrm{ft}$. Of shrubby growth and thrives in moist locations. Produces many spikes of rose-purple flowers in July and August. ................ $1.50 \quad 12.00$

MONARDA didyma rosea. $3 \mathrm{ft}$. Flowers of an attractive rose shade in July and August.

$\begin{array}{rrr} & \\ \text { From 21/4 in. pots. .................................... } & 1.10 & 12.00 \\ \end{array}$

M. didyma splendens (Blazing Beebalm). 2 to $3 \mathrm{ft}$. Bright crimson flowers in late summer. $1.20 \quad 10.00$ From 2I/4 in. pots. ................................ $1.00 \quad 8.00$

MYOSOTIS pal. semperflorens (Forget-me-not). 4 to 8 in. Many charming, light, clear blue flowers produced throughout entire summer. Prefers damp soil. (R). From 3 in. pots. $1.20 \cdot 10.00$ 
Hardy Perennial Plants-Continued

$10 \quad 100$

OENOTHERA Missouriensis (Ozark Sundrops). 6 to 8 in. Many big yellow blooms on a prostrate plant. (R).

$\$ 1.20 \$ 10.00$

PACHYSANDRA terminalis (Japanese Spurge). 6 to 9 in. Probably best of all evergreen varieties for making a ground cover. (R). From 3 in. pots. Per 1000, $\$ 90.00 \quad 1.20 \quad 10.00$

PAPAVER nudicaule (Iceland Poppy). $1 \mathrm{ft}$. Numerous flowers of various colors from orange to white are produced the entire summer. (R). $1.50 \quad 12.00$

P. orientale (Oriental Poppy). 3 to $3 \frac{1}{2} \mathrm{ft}$. Large, bright scarlet flowers with black centers. May and June.

1.50

P. or. Helen Elizabeth. $21 / 2 \mathrm{ft}$. Considered by many as the best pink. It is a rugged grower. Flowers are la-France-pink, without dark spots 2.00

P. or. Hercule. $2 \frac{1}{2} \mathrm{ft}$. Immense flowers of true scarlet.

P. or. Jeanne Mawson. $3 \mathrm{ft}$. Sparkling geraniumpink. ...................................................... 2.00

P. or. "Mrs. Perry." $3 \mathrm{ft}$. Many big apricot-rose Poppies.

1.50

P. or. Pink Beauty. $2 \mathrm{I} / 2 \mathrm{ft}$. Salmon pink. Very much like Mrs. Perry, but a better shaped plant.

$$
1.50
$$

P. or. Purity. $2 \mathrm{ft}$. Firecracker red, light gray center, mid-May; prolific.

3.50

From $2 \frac{1}{4}$ in. pots.

$2.50 \quad 20.00$

PENTSTEMON barbatus torreyi (Torrey Pentstemon). $4 \mathrm{ft}$. Spikes of scarlet blooms are produced from July to September. ......................... $1.50 \quad 12.00$

P. digitalis (Foxglove Pentstemon). $2 \mathrm{ft}$. Light purple and white flowers in early summer.

From 21/4 in. pots. .................................. $1.00 \quad 8.00$

\section{PAEONIA (Peonies)}

\section{3 to $4 \mathrm{ft}$.}

May and June. Always popular, always adaptable, always beautiful.

Albatre. Pure white, crimson flecks at center.

$$
2.00 \quad 16.00
$$

Alexander Dumas. Brilliant pink, interspersed with salmon, white and chamois. Early. .... $2.00 \quad 16.00$

Avalanche. Blush white; late. ............... 2.00 $\quad 2.00$

Baron Rothschild. Pale lilac-rose ........ $2.00 \quad 16.00$

Duchesse de Nemours. White with creamy yellow center; early. ............................................ 2.. 2.00 16.00

Edulis Superba. Mauve pink, silvery reflex; early. One of the best cut flower varieties. .. $2.00 \quad 16.00$

Eugene Verdier. Large pale hydrangea pink, outer petals lilac white. Late. ........................ 2.00 16.00

Faust. Hydrangea pink. ............................ $2.00 \quad 16.00$

Felix Crousse. Brilliant crimson; late mid-season. $2.20 \quad 18.00$

Festiva Maxima. White, flecked crimson; early.

$$
2.00 \quad 16.00
$$

Floral Treasure. Delicate salmon-pink; early.

$$
2.00 \quad 16.00
$$

Karl Rosenfeld. Pure, rich, intense crimson. 
Hardy Perennial Plants-Contimued

PAEONIA (Peonies)-Concluded $\quad 10 \quad 100$

La Palmatier. Pink.

$\$ 2.00 \$ 16.00$

Mad. Bollet. Pale pink; silvery reflex. 2.0016 .00

Mad. Boulanger. Soft pink. .................... 2.00 16.00

Mme. de Verneville. White, blush white center, crimson marks on tips of several petals. Early.

$\begin{array}{llll}2.00 & 16.00\end{array}$

Mons. Jules Elie. Fleshy pink. .............. $3.00 \quad 25.00$

Perfection. Pink. ........................................ $2.00 \quad 16.00$

Philomele. Soft pink, center yellow. .... $2.00 \quad 16.00$

Queen Victoria. White with yellow center.

$2.00 \quad 16.00$

Triomphe de L'Exposition de Lille. Big fragrant, violet-rose. ............................................... $2.00 \quad 16.00$

PEONIES, Mixed. A superb mixture of the best varieties. ................................................... $1.50 \quad 12.00$

SPLENDID SINGLE-F.LOWERED PEONIES

La Fraicheur. Blush white.

5.00

L'Etincelante. Cameo-pink, margined silver.

4.00

PHLOX. Our Phloxes are all well rooted, field grown plants.

Africa. Brilliant carmine-red, blood red eye.

$\begin{array}{rrr} & 1.20 & 10.00\end{array}$

Beacon. Brilliant cherry-red. ................ $1.20 \quad 10.00$

B. Compte. Rich amaranth floral heads.

$1.20 \quad 10.00$

Cherry Ripe. Large loose heads of luminous shade of deep rose, flushed with scarlet. ...... $1.80 \quad 15.00$

Dr. Klemm. Tall, showy white trusses, rich violet "eye." ........................................................ $1.50 \quad 12.00$

Eclaireur. Bright rosy carmine. ........... $1.00 \quad 8.00$

E. I. Farrington. Salmon-pink. Very erect.

E.20 10.00

Eiffel Tower. White with red "eye." 1.2010 .00

Enchantress. Improved Elizabeth Campbell; salmon-pink, red "eye." ........................... $1.50 \quad 12.00$

Eva Foerster. One of the better, comparatively new varieties. Large, bright salmon-rose.

$1.50 \quad 12.00$

Fiance. Beautiful, iarge, waxy-white flowers, blooms very late in the season. ...... $1.00 \quad 8.00$

Flash. One of the newer sorts. Carmine-crimson, orange-scarlet center; a splendid variety.

$1.80 \quad 15.00$

Harvest Fire. Brilliant salmon-orange flowers. Tall growing and very beautiful. ............ $2.00 \quad 15.00$

Innocence. White, late. ......................... $1.80 \quad 15.00$

Iris. Light purple. ................................. $1.00 \quad 8.00$

Leo Schlageter. Bright scarlet with deeper "eye."

$\begin{array}{rrr} & 1.50 & 12.00\end{array}$

Lillian. Lovely pure pink. ................. $1.50 \quad 12.00$

L'Esperance. Lavender-pink, white center.

Minnie West. Rich lavender pink flowers, with crimson eye. Distinct and beautiful. $1.00 \quad 8.00$

Miss Lingard. White, faint lavender eye. Early flowering. ............................................... $1.20 \quad 10.00$

Mrs. Jenkins. White; of sturdy growth.

$\begin{array}{lll}1.20 & 10.00\end{array}$

Rheinlander. Salmon-pink with red eye; early blooming. ............................................... $1.20 \quad 10.00$

Rijnstroom. Bright rose-pink. ............. $1.20 \quad 10.00$

R. P. Struthers. Tall, bright rosy-carmine with claret eye. ……........................................ $1.20 \quad 10.00$ 
Hardy Perennial Plants-Continued

10100

Salmon Glow. Flame pink, salmon shades.

$\$ 1.20 \$ 10.00$

Silverton. Large, light blue. ................ $1.80 \quad 15.00$

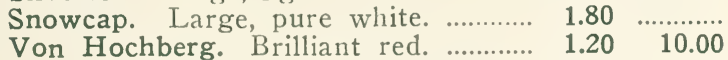

Von Lassburg. Pure white, large trusses in abund-

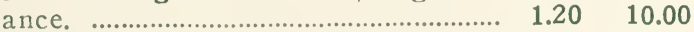

PHLOX DIVARICATA (Blue Phlox), 10 to 12 in.

Big fragrant lavender flowers in very early spring. (R)......................................................... $1.20 \quad 10.00$

From 21/4 in. pots. ................................. $1.00 \quad 8.00$

P. SUBULATA (Moss Phlox). 4 to 6 in. (R).

alba, lilacina and rosea. .......................... $1.00 \quad 8.00$ atropurpurea. Bright purple. ............. $1.20 \quad 10.00$ major. Large pink blooms. ................. $1.20 \quad 10.00$

PHYSALIS francheti (Chinese Lantern Plant). $2 \mathrm{ft}$. Big orange fruit. Fall. ........................ $1.00 \quad 8.00$

PHYSOSTEGIA Summer Snow. $2 \mathrm{ft}$. A beautiful white flowering variety of comparatively dwarf growth. .................................................... $2.00 \quad 15.00$

P. virginiana (Virginia Dragonhead). 3 to $4 \mathrm{ft}$. Pink. Mid-summer. ............................................ $1.20 \quad 10.00$

P. virginiana alba (White Dragonhead). 3 to $4 \mathrm{ft}$. White. Mid-summer. ............................. $1.20 \quad 10.00$

P. Vivid (Vivid Dragonhead). 18 to 24 in. Deep pink flowers produced continuously from mid-summer until early fall.

$1.50 \quad 12.00$

PLATYCODON mariesi (Maries Balloon-flower). 18 in. Attractive blue flowers produced in midsummer. (R). .............................................. $1.50 \quad 12.00$

P. mariesi alba. White form of the preceding.

$1.50 \quad 12.00$

PLUMBAGO larpentae (Larpente Plumbago). 6 to 8 in. Deep blue. July to October. (R). From $2 \mathrm{I} / 2$ in. pots. .............................................. $1.10 \quad 9.00$

PRIMULA veris. 6 in. Mixed colors. Late spring. (R). ....................................................... $1.80 \quad \ldots \ldots \ldots . . . .$. P. vulgaris (English Primrose). 12 to 15 in. Dark yellow. Spring. (R). From 3 in. pots. 2.20

PYRETHRUM roseum hybridum (Painted Lady). 12 to 18 in. Very attractive, daisy-like flowers of various colors from crimson to white are produced freely during the late spring and early summer months. ............................................ $1.50 \quad 12.00$

RANUNCULUS acris fl. pl. (Double flowered Buttercup). $1 \frac{1}{2}$ to $2 \mathrm{ft}$. Many double yellow cut flowers in late spring. (R). From $2 \frac{1}{4}$ in. pots. $1.00 \quad 8.00$

RUDBECKIA laciniata florepleno (Golden Glow). 5 to $6 \mathrm{ft}$. Beautiful, rather large, double golden flowers produced in great abundance throughout August and early September. .............. $1.00 \quad 8.00$

R. purpurea (Purple Coneflower). 2 to $3 \mathrm{ft}$. Purplered. Mid-summer to fall. .................... $1.20 \quad 10.00$

R. subtomentosa (Blackeyed Susan). $3 \mathrm{ft}$. Yellow, black center. Blooms continuously from late July until early September. ............................. $1.00 \quad 8.00$

SALVIA azurea grandiflora (Great Azure Sage). 3 to $4 \mathrm{ft}$. Very atiractive bright but light blue, late summer. ...................................................... $1.20 \quad 10.00$

S. pratensis (Meadow Sage). $2 \mathrm{ft}$. Deep violet. Early summer. ........................................ $1.20 \quad 10.00$ 
Hardy Perennial Plants-Continued

SANTOLINA incana (Lavender-cotton). 6 to 9 in. Attractive silvery foliage makes this a very beautiful border plant. (R).

From $21 / 4$ in. pots.

$\$ 1.20 \$ 10.00$ $1.00 \quad 8.00$

SCABIOSA caucasica (Caucasian Scabiosa). 18 to 24 in. Very attractive light blue, rather large flowers produced all summer. ...................... $1.50 \quad 12.00$

S. fisheri. 18. to 24 in. This comparatively new variety produces very attractive double flowers of sparkling lavender-blue throughout the entire summer; splendid for cutting. ..................... $1.50 \quad 12.00$

SEDUM kamtschaticum (Orange Stonecrop). 6 in. Orange flowers, late summer, golden fall foliage. (R). ...................................................... $1.00 \quad 8.00$

S. sieboldi (Siebold Stonecrop). 8 in. Crimsonrimmed, glaucous foliage; pink Sept. bloom. (R). From 21/4 in. pots. ................................... $1.00 \quad 8.00$ From 3 in. pots. .................................. $1.20 \quad 10.00$

S. spectabilis, Brilliant (Showy Stonecrop). $18 \mathrm{in.}$ Brilliant red fall flowers. ......................... $1.20 \quad 10.00$

S. spectabilis variegata (Variegated Stonecrop). 15 to 18 in. Deep old rose flowers from highly attractive foliage. $1.80 \quad 15.00$

SPIRAEA palmata (Crimson Meadow-sweet). $3 \mathrm{ft}$. Crimson-purple flowers on purple stems.

S. palmata elegans (Meadow-sweet). $3 \mathrm{ft}$. Pale pink. Early summer. .......................................... $1.80 \quad 15.00$

STACHYS lanata (Woolly Betony). 4 in. Pale purple, silvery foliage. (R).

1.00 ..............

STATICE latifolia (Sea-lavender). 18 in. Myriads of attractive small, lavender-blue flowers are produced in late summer. .............................. $1.50 \quad 12.00$

STOKESIA laevis (Cornflower Aster), 18 in. Pale blue. Late summer. A very good cut flower variety. From $2 \frac{1}{4}$ in. pots. ................................... $1.20 \quad 10.00$

THALICTRUM adiantifolium (Maidenhair Meadowrue). $3 \mathrm{ft}$. Small white June bloom from foliage like the maidenhair fern. ....................... $1.50 \quad 12.00$

THYMUS serpyllum (Mother-of-Thyme). 6 to 8 in. Fragrant foliage and purple-lilac flowers in early summer. (R). From $21 / 4$ in. pots. $1.00 \quad 8.00$

T. serpyllum coccineum. 6 to $8 \mathrm{in.}$ Dark red flowers. From 21/4 in pots. ................................... $1.00 \quad 8.00$

THERMOPSIS caroliniana. 3 to 4 in. Yellow pealike flowers in June and July. ............... $1.80 \quad 15.00$

TRADESCANTIA, Bluestone. 18 to 24 in. Flowers $\begin{array}{llll}\text { of a rich blue produced all summer. .... } & 1.80 & 15.00\end{array}$

TRITOMA pfitzeri (Bonfire Torchlily) (Red Hot Poker). 3 to $4 \mathrm{ft}$. Bright flame-orange. August to October. Makes a decidedly unusual and very attractive cut flower. ............................... $1.50 \quad 12.00$

TUNICA saxifraga (Tunicflower). 6 in. Light pink flowers all summer. (R). ................... $1.50 \quad 12.00$ From $2 \mathrm{I} / 4$ in. pots. .................................... $1.10 \quad 9.00$ 
Hardy Perennial Plants-Concluded

$10 \quad 100$

VALERIANA officinalis (Hardy Heliotrope). 3 to $4 \mathrm{ft}$. Rosy-white, delightfully fragrant flowers are Blue. Early summer. (K).

$\$ 1.20 \$ 10.00$

VERONICA amethystina (Speedwell). 8 to $10 \mathrm{in.}$ Blue. Early summer. (R). ................ $1.20 \quad 10.00$

V. incana (IVoolly Speedwell). $1 \mathrm{ft}$. Blue. Midsummer. (R). From 21/4 in. pots. ........ $1.00 \quad 8.00$

V. longifolia subsessilis (Clump Speedwell). $2 \mathrm{ft}$. Bright blue. All summer. ..................... $1.50 \quad 12.00$

V. spicata (Spike Speedwell). 18 in. Violet-blue. June and July. From $2 \mathrm{r} / 4$ in, pots. .... $1.00 \quad 8.00$

V. spicata alba (White Spike Speedwell). 15 in. Pure white, June-July. From $2 \mathrm{x} / 4$ in. pots. 1.2010 .00

VIOLA Double Russian. 6 in. Many double, deep purple flowers in early spring; very fragrant. (R). 1.80

V. Governor Herrick. 10 in. Lovely single violets for early spring and late fall. ............... $1.20 \quad 10.00$ From $21 / 4$ in pots. .................................. $1.00 \quad 8.00$

V. Jersey Gem. 6 to 8 in. Rich violet. May to October. (R). ................................................ $1.50 \quad 12.00$ From 2r/4 in. pots. ................................. $1.10 \quad 9.00$

V. Snowflake. 6 in. Pure white; single. $1.50 \quad 12.00$ From $2 \mathrm{~T} / 4$ in. pots. .................................... $1.00 \quad 9.00$

Thanks very much for the fine plants shipped on former order.

JAS. DOTY, Mgr. Srott-Florist

Sussex, N. J.

\section{We Invite You}

To visit our nursery whenever you find it convenient to do so. Not only would we enjoy chatting with you, but also we feel very sure that a visit to our nursery would be mutually profitable.

We have a large supply of well grown stock much of which you can undoubtedly handle to good advantage-so come see us-you'll sure be welcome. 


\section{FRUIT TREES}

\section{Apples}

\section{Delicious \\ Gravenstein \\ Grimes Golden \\ Hyslop (Crab) \\ Jonathan \\ McIntosh}

First-class trees
Rome Beauty

Stayman

Wealthy

Yellow Delicious

Yellow Transparent

York Imperial

\section{Extra Large Apple Trees}

In stock, we have a fairly large supply of trees which have borne fruit in the nursery rows. They vary in caliper from $1 \mathrm{~T} / 4$ to 2 inches, and we now offer them at $\$ 25.00$ per 10 trees.

The varieties that we can supply are:-

Delicious

Stayman

Jonathan

Rome Beauty

\section{Pears}

Sorry, sold out.

\section{Sweet Cherries}

Governor Wood

Lambert

Schmidt's Bigarreau

Yellow Spanish

First-class trees

10.00

90.00

\section{Sour Cherries}

Montmorency

First-class trees

10.00

\section{Peaches}

$\begin{array}{ll}\text { Carman } & \text { Hale Haven } \\ \text { Elberta } & \text { Hiley } \\ \text { Golden Jubilee } & \text { J. H. Hale }\end{array}$

First-class trees 6.50

\section{Plums}

Sorry, sold out.

\section{Quince}

Sorry, sold out.

\section{Mulberry}

Downing. Best black fruited variety.

5 to $7 \mathrm{ft}$.

\section{Apricot}

Mandarin. Large rich yellow fruit of high quality. 3 to $5 \mathrm{ft}$. 


\section{GARDEN FRUITS}

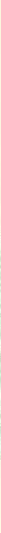

\section{Blueberries}

\section{Huckleberries}

Burlington. One of the newer varieties. Fruit is of excellent flavor, very large and quite uniform, good keeper. Medium high and crops heavily, and later in the season than other late varieties. (b).

Concord. Ripens with Pioneer, bearing large fruit with excellent flavor. (a) (b) (c).

Jersey. New variety, ripens with Rubel, with large, well flavored, attractive berries. (a) (b) (c).

June. Extra early. Berry is large, sweet and delicious. (a) (b).

Pioneer. Ripens early in the season with spikes of very blue berries. (a) (b).

Rancocas. Ripens just before Rubel, with heavy yield of tasty berries. (a) (b) (c) (d).

Rubel. Latest and heaviest bearing of all. Best for canning. (a) (b) (c).

Scammell. An improvement on the variety Jersey. (a) (b).

Stanley. Midseason; fruit large. Declared by many to be most delicious of all blueberries. (a) (b) (c) (d).
(a) 6 to 12
(b) 12 to 18
(c) 18 to 24
$10 \quad 100$
(d) 2 to $2 \frac{\mathrm{T}}{2} \mathrm{ft}$.
$6.00 \$ 50.00$
$8.00 \quad 70.00$
$10.00 \quad 90.00$
$15.00 \quad 135.00$

\section{Raspberries}

We offer Strong, Heavy, Transplanted Plants, marked Tr., and Selected Suckers, marked S. S., and Strong Tips, marked S. T. Our Raspberry plants have all been carefully examined and found to be free of mosaic.

Chief. Early, red (S. S.) ........................ $.90 \quad 7.00$

Chief. (Tr.) ................................................. $1.40 \quad 10.00$

Cumberland. Best Blackcad (S. T.) ..... $\quad .80 \quad 6.00$

Cuthbert. Dependable, red (S. S.) $\ldots . . . . . \quad .90 \quad 7.00$

Cuthbert. (Tr.) ............................................ $1.40 \quad 10.00$ 
GARDEN FRUITS-Continued

RASPBERRIES-Concluded

$10 \quad 100 \quad 1000$

Indian Summer. Best new red everbearing Raspberry. Big, attractive, delicious fruit. Spring, Summer and

Fall. (S. S.) …..........................\$ $.90 \$ 7.00$

Indian Summer. (Tr.) …............ $1.20 \quad 9.00$

Latham. Best late red. (S. S.) .. $\quad .90 \quad 7.00$

Latham. (Tr.) ............................... $1.40 \quad 10.00$

Marcy. One of the most valuable of the recently introduced red fruited varieties. (S. S.).

$\begin{array}{rrr} & .80 & 6.00\end{array}$

Marcy. (Tr.) ............................. $1.20 \quad 9.00$

Morrison. Sensational new Blackcap. (S. T.).

Newburgh. Popular midseason red. (S. S.)

$\begin{array}{rrr} & .90 & 7.00 \\ \text { Newburgh. (Tr.) ............................. } & 1.40 & 10.00\end{array}$

New Logan. Early Blackcap. (S.T.)

$\begin{array}{lll}80 & 6.00\end{array}$

Sodus. Outstanding new purple. Large and very productive. (S. T.) ................. .907 .00

Sunrise. Combines earliness - hardiness and quality. (S. S.) ................................. 1.40 .10 .00

Taylor. Best New late red. (S.S.) $\quad .90 \quad 7.00$

Taylor. (Tr.) ................................ $1.40 \quad 10.00$

\section{Blackberries}

Selected root-cutting plants, 2 yrs. old.

Blowers. Popular, hardy; midseason.

$.70 \quad 5.00 \$ 40.00$

Eldorado. Handsome and tasty. July-August. . $\begin{array}{lll}.80 & 6.00 & 50.00\end{array}$

Joy. Big in crop and berry; midseason.

$$
\begin{array}{lll}
1.20 & 9.00 \quad 75.00
\end{array}
$$

La Grange. Hardy; early, long bearing period.

$\begin{array}{llll}.80 & 6.00 & 50.00\end{array}$

Macatawa. Hardy; sweet coreless and nearly seedless fruit. .806 .00

Mersereau. Terrific yield of quality berries.

$$
\begin{array}{lll}
.80 & 6.00 & 50.00
\end{array}
$$

MT. POCONO. Our hardy, sweet delicious sort.

$$
\begin{array}{lll}
1.20 & 9.00 \quad 75.00
\end{array}
$$

NEW LOWDEN. Canadian sort, handsome, hardy and delicious. $\begin{array}{lll}1.50 & 12.00 & 100.00\end{array}$

Taylor. Late, extremely tasty. .... $\quad \begin{array}{llll}.70 & 5.00 & 40.00\end{array}$

Wasd. Good home or market berries.

$$
\begin{array}{lll}
.70 & 5.00 & 40.00
\end{array}
$$

\section{Hansen Bush Cherry}

5 to $6 \mathrm{ft}$. Wonderful discovery whose value as an ornamental shrub is rivalled only by its importance as a heavy producer of fruit.

Stocky, 2 yr. plants, 18 to 24 in.

$\$ 3.50 \$ 30.00$

Stocky, 2 yr. plants, 2 to $3 \mathrm{ft}$.

$4.00 \quad 35.00$ 
GARDEN FRUITS-Continued

\section{Dewberries}

Lucretia. Big, glossy black, delicious.

Tips

\section{The Boysenberry}

This sensational berry is apparently destined to dominate the small fruit world. It produces huge fruits, like Blackberries in general appearance, but frequently 2 inches in length. Should be trained to stakes or along wires.

Strong plants. $\$ 0.90$ per $10, \$ 7.00$ per 100 , $\$ 60.00$ per 1000 .

\section{Wineberry}

Useful fruits, for canning or wine.

No. 1 plants

$1.20 \quad 10.00$

\section{GRAPES}

All 2 yr. No. 1 (except as specified).

Our grapes are exceptionally fine in both "root" and "top." They could not well be better.

All of our Grape Vines have been transplanted at least once: hence are wonderfully well rooted.

Agawam. Deep maroon, aromatic, big bunches.

$\$ 2.00 \$ 15.00$

Fruiting age ....................................... $4.00 \quad 30.00$

Brighton. Wine red, midseason. ............. $2.00 \quad 15.00$

Fruiting age. ......................................... $4.00 \quad 30.00$

CACO. Delicious in berry, which is amber-red. We have long been proud of Caco. ............ 2.50 20.00

Fruiting age. ……................................... $5.00 \quad 40.00$

Campbell's Early. Deep blue, sweet, early.

$2.50-20.00$

Fruiting age ........................................ $5.00 \quad 40.00$

Catawba. Old red-amber favorite. .... $2.00 \quad 15.00$

Fruiting age. .......................................... $4.00 \quad 30.00$

Concord. Most popular big black Grape. $1.50 \quad 12.00$

Fruiting age. ........................................... $3.00 \quad 24.00$

Delaware. Small, delicious, red Grape. ... $2.50 \quad 20.0 \mathrm{C}$

Diamond. White; luscious. ...................... $2.00 \quad 15.00$

Fruiting age. ........................................... $4.00 \quad 30.00$

Fredonia. Early, good black; ripens before Worden.

$\begin{array}{lll}2.00 & 15.00\end{array}$

Fruiting age: .......................................... $4.00 \quad 30.00$

Moore's Early. Black, ripens before Concord.

$2.00 \quad 15.00$

Fruiting age. ........................................ $4.00 \quad 30.00$

Niagara. White, popular and delicious. $2.00 \quad 15.00$

Fruiting age. ............................................ $4.00 \quad 30.00$

Portland. Very early, large white Grape. $2.00 \quad 15.00$

Fruiting age. ........................................... $4.00 \quad 30.00$

Worden. Early, bigger and better than Concord.

Fruiting age. ...................................... $4.00 \quad 30.00$

We received the Concord Grape Order. - Nice plants.

HAWLEY \& CO.,

Lynnfield Centre, Mass. 


\section{GARDEN ROOTS}

ASPARAGUS. Because of its decided superiority over all other varieties with which we are familiar, we are now growing only one variety of Asparagus, namely Washington.

$10 \quad 100 \quad 1000$

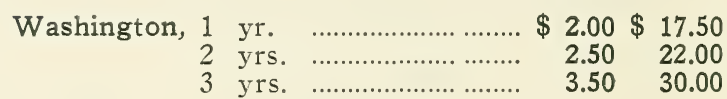

CHIVES. For soups and seasoning. Medium sized clumps. .......................................\$1.00 $\$ .00 \quad 70.00$

HORSERADISH. Easy to grow; a strong condiment. Sets ................................... $\quad .40 \quad 2.50$

LAVENDER. Sweet-scented old favorite. $2 \mathrm{I} / 4$ in. pots. .............................. $1.20 \quad 10.00$

SPEARMINT. Good for seasoning, or cool drinks. Field-grown $\quad$.................................. $1.00 \quad 8.00 \quad 70.00$

$2 \mathrm{I} / 4$ in. pots. .................................. $.90 \quad 7.00 \quad 60.00$

PEPPERMINT. Cooking plant, but may be chewed, "raw." Field-grown ................. $1.50 \quad 11.00 \quad 90.00$ $2 \mathrm{I} / 4$ in. pots. .................................. $90 \quad 90 \quad 8.00 \quad 75.00$

RHUBARB (Myatt's Linneaus). Dependable old variety. Strong selected roots. .... $\quad .80 \quad 6.00$

R. (Strawberry). A variety that produces delicious red stalks.

$1.00 \quad 7.50$

SAGE, Holt's Mammoth. Useful and beautiful.

Field-grown $1.00 \quad 8.00$

$2 \mathrm{I} / 4$ in. pots.

$.80 \quad 6.00$

TARRAGON. For soups, salads, pickie or stew. Field-grown. ................................ $1.20 \quad 9.00$

$2 \mathrm{I} / 4$ in. pots. .................................. $.90 \quad 7.00$

THYME. Seasoning plant, but also a lovely ground cover.

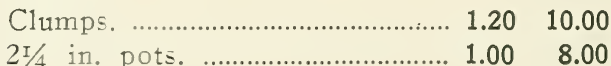

\section{Strawberry Plants}

Unfortunately, we are completely booked up on Strawberry plants for shipment this season, but for shipment after July 1st, we expect to have our usual large supply of splendid, dependable Pot-grown Strawberry plants. If interested write for special quotations. 


\section{Terms and Conditions of Sale}

The prices published in this list cancel those in all previous lists. They are based on present market conditions and are subject to change without notice.

SPECIAL NOTICE-We exercise the greatest care to keep our stock clean and true to name. Should any be otherwise, we will return the money paid or replace it with other stock, but beyond this we are not liable for damage. A sure indication of the purity of our stock is that our customers continue to deal with us year after year. A Certificate of Inspection is attached to each shipment.

CLAIMS-We do not guarantee the life of our products after they leave our Nursery, as conditions frequently exist, over which we have no control. If claims are made upon receipt of goods they will be carefully and cheerfully examined and adjusted. Any claims made 15 days after receipt of goods will not be entertained.

All orders are accepted by us subject to weather conditions and other conditions beyond our control.

PRICES-These prices apply only to orders placed by bona fide Nurserymen, Florists and Dealers. Not less than 5 of a variety and size will be supplied at the 10 rate, not less than 25 at the hundred rate, and not less than 250 at the thousand rate.

SPECIAL SELECTION-All stock when specially selected on the Nursery will be sold at prices commensurate with the value of the specimens chosen.

PACKING-All stock is carefully packed in boxes or bales, for which a charge will be made based on actual cost of packing material used. This packing charge will apply to orders which have been paid for in advance of shipment, as well as charge orders. After delivery to forwarders, all articles travel at the risk of the purchaser, and if loss or delay occurs, the forwarders alone are responsible.

TERMS-60 days net, $2 \%$ discount 10 days, from date of shipment. Interest at $6 \%$ per annum to be paid after maturity. These terms are offered to those of established credit. Cash, security, or satisfactory references are required from customers not known to us. C. O. D. orders must be accompanied by $25 \%$ of the purchase price. When ordering please use printed stationery or enclose business card.

\section{Location of}

\section{LOVETT'S NURSERY, Inc.}

World's Largest Grower of Privet

LOVETT'S NURSERY, Inc., is located one mile from Little Silver depot, two miles from Red Bank, forty miles from New York City, and five miles from Long Branch. To reach it from New York City, take the Central Railroad of New Jersey (foot of Liberty Street), or the Pennsylvania Railroad (Cortlandt Street, or 33rd Street and 7 th Avenue). From Philadelphia, take the Pennsylvania Railroad. In all cases get tickets to Red Bank. We shall be pleased to have you met at Red Bank depot; providing we are advised at least one day in advance of your anticipated arrival.

Phone Red Bank 2200 


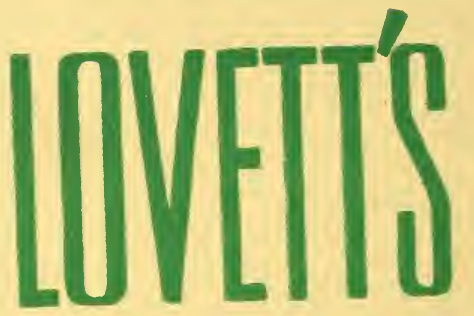

"FOR OVER SIXTY YEARS" at

LITTLE SILVER, N.J. 